0 



\section{doispontos}

Os artigos aqui publicados são indexados na CLASE (Citas Latinoamericanas en Ciencias Sociales y Humanidade) e podem ser acessados no Directory of Open Acess Journals (DOAJ), no sítio do Departamento de Filosofia da UFPR (www.filosofia.ufpr.br/doispontos < http://www.filosofia.ufpr.br/doispontos>) ou no Sistema Eletrônico de Revistas (SER).

Revista dos Departamentos de Filosofia da Universidade Federal do Paraná e da Universidade Federal de São Carlos 



\section{Justiça}

vol. 10 número 1

semestral

abril de 2013 
doispontos é uma revista vinculada aos programas de pós-graduação da Universidade Federal do Paraná e da Universidade Federal de São Carlos. Publica artigos de filosofia e de áreas afins com interesse filosófico e busca promover intercâmbio entre pesquisadores no Brasil e exterior.

\section{editores}

Bento Prado Neto (Universidade Federal de São Carlos) eVivianne de Castilho Moreira (Universidade Federal do Paraná)

\section{editor responsável pelo número "Justiça"}

Maria Isabel Limongi

\section{conselho editorial}

Adriano Fabris (Università di Pisa - Pisa, Itália), Balthazar Barbosa Filho † (Universidade Federal do Rio Grande do Sul - Porto Alegre, RS, Brasil), Bento Prado Júnior † (Universidade Federal de São Carlos - São Carlos, SP, Brasil), Carlos Alberto Ribeiro de Moura (Universidade de São Paulo - São Paulo, SP, Brasil), Eduardo Jardim (Pontificia Universidade Católica do Rio de Janeiro - Rio de Janeiro, RJ, Brasil), Franklin Leopoldo e Silva (Universidade de São Paulo - São Paulo, SP, Brasil), Jean-Michel Vienne (Université de Nantes - Nantes, França), José Arthur Giannotti (Universidade de São Paulo - São Paulo, SP, Brasil), José Oscar Marques (Universidade Estadual de Campinas - Campinas, SP, Brasil), Leiser Madanes (Universidade Nacional de Buenos Aires - Buenos Aires, Argentina), Luiz Henrique Lopes dos Santos (Universidade de São Paulo - São Paulo, SP, Brasil), Luiz Roberto Monzani (Universidade Estadual de Campinas - Campinas, SP, Brasil), Márcio Suzuki (Universidade de São Paulo - São Paulo, SP, Brasil), Marcos Lutz Müller (Universidade Estadual de Campinas - Campinas, SP, Brasil), Marilena Chauí (Universidade de São Paulo - São Paulo, SP, Brasil), Michel Malherbe (Université de Nantes - Nantes, França), Newton Bignotto (Universidade Federal de Minas Gerais - Belo Horizonte, MG, Brasil), Oswaldo Porchat (Universidade de São Paulo - São Paulo, SP, Brasil), Raul Landim Filho (Universidade Federal do Rio de Janeiro - Rio de Janeiro, RJ, Brasil), Renaud Barbaras (Université de Paris - I - Paris, França), Róbson Ramos dos Reis (Universidade Federal de Santa Maria - Santa Maria, RS, Brasil).

ISSN: 1807-3883 


\section{Editorial}

O tema da justiça encontra-se precisamente delimitado como um campo de reflexão desde Aristóteles. Desde então dois sentidos da justiça se fixaram: o da justiça geral - o conjunto das virtudes cujo cultivo é necessário para acomodar os homens uns aos outros; e o da justiça particular - a proporção adequada na distribuição de bens e poder entre as partes de uma comunidade política (justiça distributiva) e nas relações de troca e compensações realizadas em seu interior (justiça comutativa).

Se o tema da justiça geral em muitos momentos se sobrepôs ao e mesmo obscureceu o tema da justiça particular, do qual se pode dizer, com Aristóteles, que recorta com mais precisão e especifica o campo da reflexão sobre a justiça no interior do vasto campo da reflexão moral, a questão da justiça particular, mais propriamente o da justiça distributiva, ganhou contemporaneamente nova força e vigor com a obra de John Rawls e as teorias da justiça que se seguiram a dele. Não é de se espantar, portanto, que um volume como este, dedicado ao tema da justiça, terminasse por reunir tantos artigos sobre Rawls. Tratam de Rawls 4 dos 7 artigos aqui publicados. Outro, acerca de Amartya Sen, mesmo se preocupado em assinalar as fontes do seu pensamento no século XVIII, ainda gravita na órbita de Rawls e explora questões que concernem ao novo espaço por ele aberto para se pensar a justiça.

Um artigo dedicado a Aristóteles não poderia faltar, pelas razões apontadas acima. E, completando o volume, um último artigo, o menos diretamente concernido com o conceito mesmo de justiça, dedica-se a Hobbes, a quem se deve creditar a paternidade do modo contratualista de abordar a justiça, ainda que sob um viés bastante diverso daquele reconhecido por Rawls como modelo.

Desse modo, os artigos aqui reunidos, não como um dossiê previamente arquitetado para dar conta da maneira a mais completa do tema em questão, mas como o conjunto de artigos que melhor responderam a uma chamada de publicação sobre o tema, oferecem ao leitor uma pequena amostra do modo como a questão da justiça, tal como tratada pelos clássicos da filosofia, reverbera entre nós.

Maria Isabel Limongi 


\section{projeto gráfico}

Marcia Pastore

\section{capa}

fotografia de Marcia Pastore

revisão e preparação dos originais

Maria Isabel Limongi e Nayara Bertoncini

\section{impressão e acabamento}

Gráfica da Imprensa da UFPR.

\section{tiragem dessa edição}

500 exemplares

Solicita-se permuta. Exchange desired.

Biblioteca Central. Seção de intercâmbio.inter@bc.ufpr.br

Caixa Postal 19051 CEP 81531-990 Curitiba PR Brasil

endereço para correspondência address for correspondence Departamento de Filosofia da Universidade Federal do Paraná

R. Dr. Faivre 405 6o andar 80060-140 Curitiba PR Brasil 0xx4133605098

Departamento de Filosofia e Metodologia das Ciências da Universidade Federal de São Carlos Rodovia Washington Luís km 235 Monjolinho caixa postal 676

13565-905 São Carlos SP Brasil

doispontos@ufpr.br

endereços eletrônicos da doispontos

www.ser. ufpr.br/doispontos

www.filosofia.ufpr.br/ 


\section{Sumário}

11 Os construtivismos kantianos e a construção dos princípios de justiça na obra de Rawls

Antonio Saturnino Braga

37 Justiça como equidade e o problema da razoabilidade Denis Coitinho Silveira

610 debate dos desencontros: uma avaliação das críticas de Michael Sandel ao liberalismo de John Rawls Flávio Azevedo Reis

83 Economia Política e as raízes da posição original em Rawls Fabricio Pontin

103 Ética, economia e justiça: a escolha social no pensamento de Sen e Smith Fábio Creder e Luiz Bernardo Leite Araújo

127 Os conceitos de justo e injusto em Aristóteles: entre EN V,1 e EN V,9 Mateus de Campos Baldin

143 Potentia e Potestas no Leviathan de Hobbes Maria Isabel Limongi

167 Contents

171 Chamada para artigos Call for papers

173 Instruções aos autores

177 Versão para o Inglês 
0 0 


\title{
Os construtivismos kantianos e a construção dos princípios de justiça na obra de Rawls
}

\author{
Antonio Saturnino Braga \\ antoniofsbraga@uol.com.br \\ Universidade Federal do Rio de Janeiro (UFRJ), Rio de Janeiro, Brasil
}

resumo 0 objetivo do presente artigo é defender as seguintes teses: em primeiro lugar, as teorias da justiça de Habermas e Rawls devem ser vistas como duas versões do construtivismo kantiano, entendido como abordagem metaética que pretende reunir antirrealismo e cognitivismo forte; em segundo lugar, o contraste com o "construtivismo reconstrutivista" de Habermas ajuda a esclarecer de que modo a teoria de Rawls atende à pretensão de universalidade própria do cognitivismo forte. Ao realçar o fato de que o construtivismo de Rawls está baseado no trabalho reflexivo da consciência individual, o contraste com Habermas permite compreender em que sentido os conceitos de equilíbrio reflexivo e consenso sobreposto designam um ideal com pretensão de validade universal, o que desmente o particularismo implicado nas interpretações coerentistas e relativistas destes conceitos. palavras-chave Justificação Moral; Construtivismo Kantiano; Habermas; Rawls; Posição Original; Equilíbrio Reflexivo

Entendido como posição no domínio da metaética, o construtivismo kantiano caracteriza-se pela ambição de reunir as três seguintes teses: antirrealismo em relação a propriedades e fatos especificamente morais, cognitivismo forte em relação à justificação de enunciados morais substantivamente determinados, e internalismo em relação à conexão entre razões epistêmicas (razões para crer na validade de determinados enunciados morais) e razões para agir, ou motivos (O’NEILL, 2003, p. 347-349). Este projeto está centrado no conceito kantiano de razão prática. Isto não implica que não se possa discutir até que ponto a filosofia moral do 
próprio Kant seria construtivista. Talvez seja possível defender a hipótese de que a teoria construtivista pressupõe um enquadramento da racionalidade prática mais intersubjetivista do que aquele que se deve atribuir à época e às obras do próprio Kant.

Independentemente do debate sobre esta questão, dois fatos são indiscutíveis. Em primeiro lugar, toda apropriação do conceito kantiano de razão prática efetuada no enquadramento intersubjetivista típico de nossa época tem necessariamente de ser construtivista. Em segundo lugar, admitindo-se que este enquadramento caracteriza-se pela tese do pluralismo das concepções de boa vida, as morais kantianas de nossa época, na medida mesmo em que têm de ser construtivistas, têm de conceder primazia ao conceito de justiça, em relação aos valores mais diretamente associados à noção de boa vida. Em nossa época, as interpretações da concepção kantiana de razão prática são antes de tudo teorias da justiça - o que não implica que elas não possam ser também, secundariamente, teorias sobre o bem, ou sobre o que é bom na vida humana.

Pode-se afirmar que as interpretações contemporâneas da moral kantiana bifurcam-se em duas grandes tradições, a rawlsiana e a habermasiana - já se pode falar aqui de tradições, considerando-se o grande número de filósofos que exercem sua energia intelectual e criativa com base nos escritos de Rawls e Habermas. Ao afirmarmos isso, estamos querendo dizer que, ao serem enfocadas do ponto de vista da metaética, essas duas tradições devem ser vistas como expressões do construtivismo kantiano em geral. Mais precisamente, estamos querendo dizer que, desse ponto de vista, o "reconstrutivismo" de Habermas deve ser visto como uma forma de interpretar e realizar as ambições construtivistas acima mencionadas.

Admitindo-se que a abordagem construtivista pressupõe um enquadramento grosso modo intersubjetivista da racionalidade prática, é forçoso admitir também que este enquadramento permite diferentes concepções sobre a relação entre a consciência individual e o contexto intersubjetivo no qual se insere a racionalidade prática, e sobre o papel que a teoria moral pode e deve exercer neste relacionamento. $\mathrm{O}$ enquadramento intersubjetivista significa que qualquer exercício individual da racionalidade prática tem de levar em consideração demandas e interesses dos outros indivíduos, frequentemente conflitantes com as nossas próprias demandas e interesses, e tem, necessariamente, de orientar-se para um entendimento 
ou acordo com os outros indivíduos. Mas há duas maneiras de conceber as condições ou exigências constitutivas deste exercício grosso modo intersubjetivista da racionalidade prática, ou do procedimento deliberativo no qual ele se encarna.

Em primeiro lugar, mesmo admitindo que tais condições apresentam um aspecto ideal ou idealizado, o teórico moral pode concebê-las como idealizações em certo sentido enraizadas nas interações comunicativas e sociais formadoras de cada consciência individual, cuja reflexão, por isso mesmo, se exerce necessária e universalmente a partir de, e por meio de, interações dialógicas concretas com os outros (McCARTHY, 1994, p. 4549). Desse ponto de vista, o aspecto ideal das condições remete à dinâmica de aperfeiçoamento contínuo dos pressupostos grosso modo normativos das interações comunicativas formadoras da consciência individual, um aperfeiçoamento que diz respeito tanto ao modo de operacionalizar estes pressupostos quanto ao grau em que eles são efetivamente cumpridos. Por outro lado, numa segunda interpretação das condições ideais do procedimento racional, o teórico moral pode remetê-las primordialmente à consciência individual que, partindo de sua experiência das relações com os outros, reflete sobre o modo idealmente correto ou justo de considerar as demandas e pontos de vista dos outros e chegar a um acordo com os outros (SCANLON, 1998, p. 189-206). No primeiro caso, o solo em que germina e floresce o exercício intersubjetivista da racionalidade prática consiste em interações dialógicas reais e concretas, indefinidamente aprimoradas; no segundo caso, ele consiste na reflexão da consciência individual a respeito do modo maximamente razoável de ponderar os interesses e pontos de vista dos outros.

No primeiro caso, o papel da teoria moral restringe-se a reconstruir a dinâmica de aperfeiçoamento contínuo de interações comunicativas e sociais anteriores a toda teoria. Nesse caso, em outras palavras, trata-se de reconstruir o modo pelo qual tal processo é desencadeado e sustentado por idealizações emanadas de tais interações e facticamente influentes nas mesmas. No segundo caso, o papel da teoria moral é mais propositivo: trata-se de propor à consciência individual as condições ideais do exercício intersubjetivista de sua racionalidade prática, definido como um exercício que, por orientar-se para um acordo racional (razoável) ou justo com os outros, precisa considerar as demandas e interesses dos outros de um modo 
perfeitamente razoável ou justo. Nesse caso, em outras palavras, o papel do teórico moral é propor à consciência individual um modelo ideal de exercício da razão prática, esperando que esse modelo seja reflexivamente chancelado por cada consciência individual. Ora, admitindo-se que as duas concepções representam duas manifestações do construtivismo kantiano em geral, a primeira equivale ao "construtivismo reconstrutivista" da tradição habermasiana, e a segunda ao "construtivismo construtivista" da tradição rawlsiana.

Nosso propósito no presente trabalho é utilizar o contraste entre esses dois tipos de construtivismo para tentar esclarecer de que modo e até que ponto a teoria de J. Rawls cumpre a ambição construtivista de reunir antirrealismo e cognitivismo forte. É comum afirmar-se que ao longo de sua obra Rawls foi progressivamente abandonando a pretensão de validade universal própria do cognitivismo forte, em favor de uma posição, grosso modo, relativista, centrada nas convicções compartilhadas em uma cultura política específica. Se isto for verdade, será forçoso admitir que Rawls não pode ser considerado um construtivista (kantiano) pleno. OnoraO'Neill, por exemplo, parece comprometer-se com este veredicto, ao afirmar que "nas últimas versões de sua teoria da justiça, Rawls apresenta uma concepção de cidadania democrática no interior de uma sociedade limitada como a fonte e contexto do raciocínio sobre a justiça" (O’NEILL, 2003, p. 360). Ora, nosso propósito no presente trabalho é utilizar o contraste entre os construtivismos de Habermas e Rawls para questionar esta interpretação de O’Neill e propor uma interpretação da obra de Rawls mais simpática ao construtivismo kantiano em geral.

O objetivo da própria O’Neill é examinar a evolução das noções de "construtivismo" e "construtivismo kantiano" na obra de Rawls, contrastando-as com o construtivismo kantiano que segundo ela se pode e deve atribuir ao próprio Kant. A conclusão da autora pode ser resumida nas afirmações de que "há razões para pensar que a concepção de Kant da justificação ética é mais radicalmente construtiva do que aquela que Rawls propõe" (O’NEILL, 2003, p. 354), na medida em que "Kant, ao contrário de Rawls, compromete-se com uma explicação fortemente construtiva não apenas da justiça, e de modo mais abrangente da ética, mas, de modo mais radical, da própria razão prática" (Idem, p. 362-363). Para a autora, o construtivismo de Rawls limita-se à construção dos 
princípios de justiça por meio da concepção de racionalidade prática modelada no procedimento hipotético da Posição Original. Em relação à justificação da própria Posição Original, entretanto, as duas concepções propostas por Rawls, a do equilíbrio reflexivo e a do consenso sobreposto, não podem ser consideradas construtivistas, na medida em que esvaziam a pretensão de validade universal essencial ao cognitivismo forte típico do construtivismo pleno. Para O'Neill, a concepção do equilíbrio reflexivo equivale a uma fundamentação meramente coerentista da Posição Original, enquanto a ideia do consenso sobreposto enfraquece ainda mais a justificação oferecida por Rawls, aproximando-a de uma posição claramente relativista.

Em contraste com Rawls, Kant oferece, segundo ela, uma fundamentação construtivista da própria razão prática; mais precisamente, Kant oferece uma fundamentação construtivista do princípio supremo da razão prática, o imperativo categórico. Embora nosso objetivo não seja avaliar a interpretação do próprio Kant exposta por O’Neill neste artigo específico, vale destacar que os argumentos por meio dos quais ela contrasta Kant com Rawls parecem indicar que ela não leva na devida conta uma distinção que é essencial para a compreensão não apenas da fundamentação estritamente kantiana da razão prática, mas também do projeto do construtivismo kantiano em geral - e esta afirmação é válida independentemente da posição que se queira adotar a respeito da hipótese de que o enquadramento kantiano da razão prática não é suficientemente intersubjetivista para poder ser considerado construtivista. Formulando a questão em termos kantianos, trata-se da distinção entre a fundamentação da fórmula da lei universal como fórmula de aplicação do imperativo categórico e, por outro lado, a fundamentação da efetividade motivacional do mesmo como norma incondicionalmente válida para os sujeitos racionais finitos.

No contexto da teoria construtivista e/ou kantiana, fundamentar a razão prática é uma tarefa que se desdobra em dois níveis intimamente relacionados, mas logicamente distintos. Em primeiro lugar, é preciso justificar a fórmula ou critério por meio do qual se exerce a razão prática, que é a fórmula da possibilidade de universalização, ou, nas versões mais atuais marcadas pela primazia da intersubjetividade, a fórmula da aceitabilidade ("concordabilidade") universal, associada ao critério da imparcialidade. 
Em segundo lugar, é preciso fundamentar a efetividade normativa da razão pura prática, mostrar que ela não é mera fantasia dos teóricos kantianos. Nesse segundo nível, trata-se de mostrar que a razão prática pura tem autoridade e efetividade, ou seja, poder de afetar e motivar as atitudes, escolhas e atos dos sujeitos racionais finitos. Na obra de Kant o primeiro nível da fundamentação é desenvolvido, por exemplo, nas duas primeiras seções da Fundamentação da Metafísica dos Costumes, onde Kant justifica a fórmula da possibilidade de universalização extraindo-a do simples conceito de um dever categórico ou incondicionado, pressuposto como dado. O segundo nível é exemplificado pelo argumento desenvolvido na terceira seção, depois substituído pelo argumento do "fato da razão"; trata-se aí de fundamentar a efetividade normativa deste conceito de dever categórico, mostrando onde se enraíza seu poder de afetar e motivar as atitudes, escolhas e ações humanas.

A necessidade de atender de uma forma "internalista" a esses dois níveis de fundamentação é uma característica dos construtivismos kantianos em geral, na medida em que estes se apropriam do conceito kantiano de razão prática. Ora, no construtivismo especificamente rawlsiano, é preciso admitir que a concepção da Posição Original não atende a nenhum desses dois níveis de fundamentação. Ela atende a um terceiro nível, o nível da justificação de princípios de justiça conteudisticamente determinados. Em outras palavras, a Posição Original representa um modelo ideal de exercício da razão prática; enquanto tal, ela decerto representa uma estratégia de justificação dos princípios conteudísticos de justiça propostos por Rawls, mas não uma estratégia de fundamentação deste exercício - nem fundamentação do critério que o governa (o critério da concordabilidade universal, associado à imparcialidade), nem fundamentação da sua normatividade, ou seja, da sua autoridade e efetividade em relação às escolhas e ações humanas.

Para poder ser considerado um construtivista pleno, Rawls precisa cumprir a exigência de justificação da própria Posição Original. Em outras palavras, Rawls precisa cumprir a exigência de fundamentação do exercício da racionalidade prática idealizado no experimento hipotético da Posição Original, nos dois níveis em que essa exigência se desdobra. Ora, admitindo-se com O’Neill que os conceitos do equilíbrio reflexivo e do consenso sobreposto equivalem justamente a estratégias 
de fundamentação da Posição Original, uma interpretação construtivista de Rawls precisa atacar a afirmação de que tais conceitos são, respectivamente, coerentista e relativista, ou seja, incompatíveis com a pretensão cognitivista forte típica dos construtivismos kantianos. Trata-se de mostrar que esses conceitos, assim como a relação entre eles, são compatíveis com a pretensão de validade universal própria do cognitivismo forte. É o que tentaremos fazer na terceira seção do presente trabalho, depois de proceder a uma análise um pouco mais detalhada do contraste entre os construtivismos de Habermas e Rawls.

Nosso propósito, como dito acima, é utilizar este contraste para defender uma interpretação plenamente construtivista de Rawls. A estrutura de nossa argumentação será constituída pelas seguintes hipóteses: o contraste com Habermas torna mais claro o fato de que o construtivismo de Rawls está centrado na consciência individual, no trabalho reflexivo da consciência individual. Este fato não anula a perspectiva intersubjetivista e o caráter grosso modo pragmático da justificação dos princípios de justiça, essenciais para todas as formas de construtivismo kantiano; por outro lado, o reconhecimento deste fato permite compreender que os conceitos de equilíbrio reflexivo e consenso sobreposto não se referem a um acordo essencialmente histórico e cultural, e nesse sentido particular, mas designam um ideal com pretensão de validade universal, concebido em termos de perfectibilidade indefinida do trabalho reflexivo da consciência individual.

\section{Razão prática, construtivismo reconstrutivista e construtivis- mo construtivista}

As abordagens construtivistas sustentam que, embora as prescrições e princípios morais possam ser justificados, e justificados num sentido forte ou exigente, tal justificação se desenvolve numa perspectiva antirrealista, rejeitando, portanto, o pressuposto de que há propriedades morais objetivas, no sentido de independentes dos sujeitos que usam o vocabulário moral. Assim, a primeira ambição do construtivismo moral é defender a possibilidade e viabilidade de um projeto de justificação que exclui o ideal de adequação a propriedades e fatos de uma realidade independente. 
Mais precisamente, trata-se de defender a viabilidade de um projeto de justificação que exclui qualquer referência a um mundo objetivo, no sentido de independente dos sujeitos do conhecimento moral. Como veremos logo a seguir, tal projeto sem dúvida depende de um fator justificador que não está ao inteiro dispor dos sujeitos empíricos, e que nesse sentido é objetivo, mas tal fator, ao contrário do que ocorre com a justificação efetuada no âmbito do conhecimento do mundo natural, não remete a propriedades de uma realidade independente, mas consiste na própria razão prática pura, tomada como um poder simultaneamente interno aos sujeitos empíricos e superior às razões que lhes são simplesmente dadas, que podem ser chamadas de razões meramente subjetivas. Trata-se, por exemplo, de desejos, atitudes e crenças empiricamente dadas nas diferentes culturas.

Para esclarecer a ambição construtivista de combinar antirrealismo e cognitivismo forte, pode-se recorrer à teoria discursiva desenvolvida por Habermas. Ao propormos isso, estamos sugerindo que, numa interpretação mais flexível da forma discursiva de justificação prática, a teoria construtivista de Rawls pode ser considerada uma teoria discursiva. Nessa interpretação mais flexível, o discurso prático não necessariamente equivale a processos reais ou concretos de discussão com os outros, mas pode ser entendido como um processo de discussão hipoteticamente desenvolvido por um sujeito individual que idealmente dialoga com outros sujeitos, outros pontos de vista, tentando discernir princípios que esses outros sujeitos, tomados como pessoas perfeitamente racionais ou razoáveis, poderiam e deveriam aceitar. Nessa interpretação mais flexível, embora a reflexão do sujeito razoável exija abertura e experiência em relação às demandas, interesses e pontos de vista dos outros sujeitos em geral, ela não exige participação real em discussões concretas, como ocorre na interpretação estritamente habermasiana da forma discursiva de justificação. No terreno constituído pela experiência da relação com os outros em geral, o "discurso" rawlsiano constitui uma espécie de discussão ideal da consciên-cia consigo mesma, uma discussão entre a consciência empiricamente condicionada e os apelos da razão pura.

Assim, para esclarecer a ambição construtivista de combinar antirrealismo e cognitivismo forte, recorreremos de início a elementos conceituais próprios da teoria discursiva desenvolvida por Habermas, destacando 
logo a seguir as características pelas quais o "discurso" prático rawlsiano distingue-se do discurso estritamente habermasiano. Na etapa inicial, tentaremos esclarecer a ambição construtivista recorrendo às análises de Habermas sobre as diferenças entre duas formas de justificação discursiva, próprias, respectivamente, do âmbito do conhecimento teórico e do âmbito do conhecimento moral. Com efeito, a ambição construtivista, que é própria do discurso prático, fica mais clara ao ser contrastada com uma forma de justificação que, apesar de discursiva ou intersubjetivista, não é antirrealista, ao contrário, envolve uma concepção grosso modo realista a respeito das propriedades do mundo natural.

Com base em análises desenvolvidas por Habermas, pode-se afirmar o seguinte: uma teoria discursiva representa, simultaneamente, uma concepção da justificação de nossos enunciados e uma concepção da validade cognitiva gerada por essa justificação (HABERMAS, 1996, p.34-39). No âmbito da justificação dos nossos enunciados, a teoria discursiva equivale a uma concepção pragmática da justificação, que pretende substituir a concepção semântica. Para a concepção semântica, uma sentença é justificada quando pode ser logicamente derivada de sentenças básicas individualmente especificáveis, cuja verdade é por sua vez imediatamente acessível à percepção ou intuição. Para a concepção pragmática, em contrapartida, a justificação consiste numa prática essencialmente intersubjetiva, na qual o valor justificatório das intuições depende de razões intersubjetivamente partilhadas ou partilháveis, ou seja, razões de caráter essencialmente intersubjetivo.

No âmbito da teoria discursiva, a concepção pragmática da justificação associa-se à concepção epistêmica da validade cognitiva de nossos enunciados, que pretende substituir concepções grosso modo correspondentistas, entre as quais um habermasiano poderia incluir a concepção defendida por E. Tugendhat em Propedêutica Lógico-Semântica (TUGENDHAT, 1983, cap. 13). Embora admita que os fatos são entidades linguisticamente mediadas, ou seja, mediadas pela aplicação correta de predicados linguísticos, a concepção de Tugendhat baseia os fatos nas percepções de indivíduos linguisticamente competentes, ou seja, competentes na aplicação de predicados elementares. Ora, um habermasiano poderia argumentar que, ao basear os fatos em percepções individuais, independentes das discussões intersubjetivas, este tipo de concepção acaba por reintroduzir, ainda que 
de forma indireta e, nesse sentido, disfarçada, a ideia da correspondência à realidade independente - independente, a saber, das divergências, discussões e acordos dos sujeitos do conhecimento. A concepção epistêmica, em contrapartida, além de reforçar a tese de que fatos equivalem a enunciados cognitivamente válidos, pretende depurar a noção de validade cognitiva de todo sentido correspondentista, apresentando-a em termos de aceitabilidade racional e interpretando pragmaticamente a noção de aceitabilidade racional, ou seja, situando tal noção no quadro eminentemente intersubjetivo da discussão ou discurso.

Para dar continuidade ao contraste entre as duas espécies de justificação discursiva, próprias, respectivamente, do âmbito teórico e do âmbito prático, vale a pena complementar as análises mais recentes de Habermas com uma recuperação da noção de "interesses de conhecimento", introduzida por ele no final da década de sessenta. Usando esta noção de uma forma relativamente livre, independente do modelo de teoria crítica tentado por Habermas antes da sua "virada linguística", pode-se afirmar o seguinte: situar a aceitabilidade racional no quadro essencialmente intersubjetivo da discussão implica afirmar que sentido e critérios da aceitabilidade racional têm a ver com os interesses humanos (intersubjetivamente partilhados) subjacentes aos diferentes âmbitos do discurso. No âmbito do discurso teórico, o interesse fundamental é o interesse de êxito ou sucesso na lida com o "mundo objetivo", entendido como realidade que não está ao nosso inteiro dispor. Ora, este tipo de interesse acarreta pressupostos, grosso modo, realistas, que estão totalmente ausentes do âmbito do conhecimento prático ou moral. Neste último, com efeito, o interesse fundamental pode ser formulado como interesse na construção de um mundo social justo, ou seja, interesse na reorganização do mundo social segundo princípios de justiça construídos pela razão prática intersubjetivamente exercida.

Para Habermas, dizer que os princípios de justiça corretos são construí-dos pela razão prática intersubjetivamente exercida equivale a dizer que eles são descobertos em discernimentos morais próprios desta nossa faculdade (HABERMAS, 1996, p. 38-39). Entendendo a noção de construção em termos de "aquilo que está ao nosso dispor", pode-se afirmar que cabe a nós construir um mundo social justo, ou reorganizar o mundo social segundo princípios de justiça corretos. Entendendo a noção de descoberta 
em termos de "aquilo que não está ao nosso dispor", pode-se afirmar que o discernimento dos princípios de justiça corretos é uma questão de descoberta, na medida em que provém de condições racionais que em certa medida se impõem a nós - o que significa, justamente, que elas não estão ao nosso inteiro dispor. Tais condições são expressões da razão prática pura intersubjetivamente orientada, tomada como faculdade simultaneamente interna aos sujeitos empíricos $e$ superior às convicções, preferências e objetivos que lhes são simplesmente dados. $\mathrm{O}$ aspecto de descoberta equivale ao sentido estritamente cognitivo ou epistêmico dos enunciados de justiça corretos (lembrando que, no vocabulário de Habermas, a correção representa uma forma de validade cognitiva análoga à verdade. No vocabulário de Rawls, interpretado em termos de cognitivismo forte, o adjetivo correspondente seria "razoável").

Entretanto, na medida em que a razão prática pura é em certo sentido interna aos sujeitos do conhecimento moral, a descoberta efetuada nos discernimentos puramente racionais pode ser considerada uma espécie de construção, efetuada pela racionalidade intersubjetivamente orientada ou exercida - desde que se depure o conceito de construção da ideia de "aquilo que está ao nosso dispor". Esta espécie de interpenetração entre construção e descoberta é expressa por Habermas na seguinte afirmação: "O sentido construtivista dos juízos morais, compreendido segundo o modelo da autolegislação, não deve ser esquecido; mas tampouco se deve apagar o sentido epistêmico das justificações morais" (HABERMAS, 1996, p. 39. Grifo meu).

Apesar de baseada em noções habermasianas, a exposição geral do construtivismo feita até aqui pode ser considerada compatível com a tradição rawlsiana, ou, pelo menos, com a leitura estritamente cognitivista da obra de Rawls, que é a que estamos adotando neste trabalho. Como afirmado anteriormente, gostaríamos agora de passar para um segundo momento de nossa exposição, aquele no qual as duas tradições se separam.

No âmbito do construtivismo kantiano em geral, a tese de que os princípios morais corretos ou razoáveis são construídos pelos sujeitos desdobra-se em dois momentos complementares. Em primeiro lugar, normas justas da interação social são construídas por meio de um procedimento de discussão ou deliberação que envolve demandas e pontos de vista conflitantes, colocados por diferentes sujeitos. Em segundo lugar, a construção 
destes princípios equivale ao acordo (entendimento) intersubjetivo alcançado neste procedimento grosso modo discursivo. Como já foi afirmado, este procedimento inclui um aspecto ideal, mas há duas interpretações divergentes desta idealidade. $\mathrm{Na}$ interpretação habermasiana, a idealidade consiste na perfectibilidade indefinida da operacionalização e cumprimento dos pressupostos normativos das discussões práticas em geral. Esta perfectibilidade equivale à dinâmica de desenvolvimento da razão prática dos sujeitos comunicativamente relacionados, centrada na possibilidade (real) da razão libertar-se das determinações, grosso modo, heterônomas, ou seja, deixar de ser empiricamente condicionada e tornar-se razão prática pura (HABERMAS, 1999, p. 305).

No construtivismo habermasiano, o procedimento construtivo é ideal no sentido de estar orientado para a plena realização de idealizações emanadas das discussões práticas concretas, e facticamente influentes nas mesmas. Este sentido da idealidade do procedimento não implica que os sujeitos que devem empreendê-lo sejam sujeitos idealizados, ou sujeitos que apenas hipoteticamente se elevam ao ponto de vista da razão prática pura. Ao contrário, na versão habermasiana o procedimento ideal é apresentado como um procedimento a ser concretamente realizado pelos sujeitos empíricos, e que será realizado à medida que estes cumprirem de modo integral ou perfeito certas condições ideais sugeridas pelas - e nesse sentido presentes nas - pressuposições normativas das discussões práticas em geral. A realização plena do procedimento ideal (ou a realização plena da razão prática pura) é por sua vez um ideal de que os sujeitos empíricos podem concretamente se aproximar. No construtivismo habermasiano, portanto, princípios corretos são enunciados cognitivamente válidos produzidos (discernidos e construídos) pelos sujeitos concretos em condições ideais. Não cabe ao teórico moral propor nenhuma hipótese a respeito de quais seriam estes princípios. Ele deve aguardar o veredito a ser produzido pela discussão dos sujeitos concretos.

Se as duas tradições do construtivismo kantiano admitem a tese de que a construção-discernimento das normas corretas implica algum tipo de idealização, na tradição rawlsiana tal idealização deixa de ser referida primordialmente às interações comunicativas que enquadram e enformam os sujeitos concretos, e passa a ser referida primordialmente aos sujeitos (individuais) que empreendem hipoteticamente o procedimento 
deliberativo de orientação intersubjetiva. O procedimento ideal é um procedimento empreendido por sujeitos ideais, ou seja, sujeitos que encarnam o ideal da razão prática pura. No vocabulário mais específico de Rawls, trata-se dos participantes da Posição Original. Trata-se de sujeitos hipotéticos; mais precisamente, trata-se de uma posição à qual os sujeitos concretos hipoteticamente se transportam ao refletirem sobre o modo maximamente razoável ou justo de deliberar sobre princípios de justiça. Tanto os sujeitos concretos quanto os sujeitos ideais em que os concretos hipoteticamente se transformam partem do pressuposto de que deliberar sobre princípios de justiça implica considerar as demandas e pontos de vista dos outros sujeitos, de modo a alcançar um entendimento essencialmente intersubjetivo. A Posição Original representa um modelo do modo correto ou razoável de realizar este exercício de consideração das demandas e interesses dos outros, tomado como um exercício que, embora orientado para o entendimento intersubjetivo, é realizado por sujeitos essencialmente individuais, de um modo hipotético, no terreno do pensamento. A sede da razão prática pura é o sujeito individual, não a relação intersubjetiva - mas a racionalidade deste sujeito consiste na capacidade de dialogar hipoteticamente com outros sujeitos em geral, de alcançar um acordo hipotético com sujeitos que apresentam interesses e pontos de vista divergentes daqueles a que ele empiricamente está inclinado.

No construtivismo habermasiano a racionalidade prática é situada no plano das interações comunicativas que desde sempre enquadram e enformam os sujeitos concretos. O procedimento ideal equivale nesse caso à realização plena de exigências fortes em certo sentido presentes em tais interações comunicativas - no sentido, a saber, de condições ideais que os participantes em alguma medida reconhecem, e que por isso são facticamente influentes. No construtivismo rawlsiano, em contrapartida, a racionalidade prática é situada no plano dos sujeitos individuais que empreendem hipoteticamente o procedimento intersubjetivo de construção dos princípios de justiça.

A diferença entre o construtivismo reconstrutivista de Habermas e o construtivismo construtivista de Rawls é, portanto, uma diferença nas tarefas respectivamente assumidas em cada uma das tradições. $\mathrm{Na}$ tradição habermasiana o teórico moral assume uma função meramente reconstrutiva: trata-se apenas de reconstruir exigências fortes presentes e em 
certa medida reconhecidas nos processos comunicativos e discursivos que prefiguram o procedimento intersubjetivo plenamente racional. Na tradição rawlsiana, em contrapartida, o teórico moral assume duas funções em certo sentido construtivas. Sua "construção" equivale à colocação de duas propostas para os sujeitos concretos. Em primeiro lugar, ele propõe aos sujeitos um modelo ideal de exercício da racionalidade prática. Em segundo lugar, uma vez que a plausibilidade deste modelo para os sujeitos concretos depende dos princípios de justiça que seriam construídos pelos sujeitos ideais que o empreendem, cabe ao teórico moral apresentar aos sujeitos concretos uma hipótese a respeito de quais princípios seriam acordados por estes sujeitos ideais.

$\mathrm{Na}$ teoria de Rawls, estas duas funções construtivas são realizadas por meio do experimento hipotético da Posição Original. Cabe enfatizar que a realização dessas funções construtivas é algo que o teórico faz ao colocar determinadas propostas para a apreciação reflexiva dos sujeitos concretos. O teórico não constrói os princípios de justiça; ele propõe aos sujeitos concretos um modo de construí-los. A construção realizada pelo teórico é a construção de uma proposta a ser reflexivamente endossada pelos sujeitos concretos. Isto significa que o construtivismo rawlsiano não se esgota no modelo construtivo representado na Posição Original; ele inclui também um método de justificação deste modelo para os sujeitos concretos. Pode-se afirmar que os conceitos de equilíbrio reflexivo e consenso sobreposto definem o método defendido por Rawls. A questão é: será que estes conceitos atendem de modo satisfatório à pretensão de validade universal típica do cognitivismo forte?

\section{Construtivismo, Posição Original, Equilíbrio Reflexivo e Consenso Sobreposto}

Ao propor um modelo de exercício da razão prática para apreciação reflexiva dos sujeitos concretos, Rawls se deixa orientar por duas preocupações. Em primeiro lugar, é preciso que o modelo possa ser justificado para estes sujeitos. Para Rawls, esta justificação não pode espelhar-se na ideia kantiana de uma derivação puramente analítica a partir do conceito de dever ou lei como forma geral da moralidade. Ela tem de recorrer 
às crenças conteudísticas sobre a moralidade adotadas pelos sujeitos aos quais ela se dirige. Ela equivale a uma espécie de equilíbrio entre tais crenças e o modelo ideal proposto, um equilíbrio "reflexivo". Como veremos logo a seguir, o equilíbrio reflexivo não implica que a justificação tenha de ficar presa ou subordinada a tais crenças; implica apenas que o trabalho de justificação é um trabalho que opera sobre (a partir de) o solo destas crenças. Mais precisamente, de acordo com a interpretação que será defendida mais à frente, na concepção do equilíbrio reflexivo a justificação aparece como um equilíbrio indefinidamente aprimorável. A ênfase da tarefa de justificação não recai tanto no convencimento dos sujeitos empíricos, mas na sensibilização dos mesmos para as exigências e apelos da razão prática pura.

Considerando-se que o modelo da Posição Original deve ser justificável para todos os sujeitos aos quais é proposto, compreende-se a primeira preocupação de Rawls: trata-se de propor um modelo o mais delgado possível, ou seja, que incorpore exigências e condições as mais simples e plausíveis possíveis, ou as mais fracas possíveis (RAWLS, 1971, p. 20). Por outro lado, porém, as condições incorporadas no modelo precisam ser fortes o suficiente para gerar um resultado bem determinado, ou seja, para fundamentar princípios capazes de efetivamente orientar a resolução das questões de justiça. Condições demasiado delgadas podem ser insuficientes para a fundamentação de princípios determinados e interessantes. Tomemos, por exemplo, as condições da aceitabilidade universal e da imparcialidade. Elas certamente estão incorporadas no modelo representado na Posição Original. De acordo com este modelo, com efeito, o exercício da razão prática orienta-se pelo critério de que princípios corretos são princípios que podem ser aceitos por todos os possíveis concernidos, ou seja, que podem ser objeto de um acordo ou contrato entre todos os concernidos. E os sujeitos (ideais) representados no modelo deliberam de forma absolutamente imparcial, eles ficam impedidos de avaliar os possíveis princípios segundo a conveniência ou inconveniência dos mesmos para seus interesses e posições particulares. No modelo da Posição Original, a condição da imparcialidade é incorporada sob a forma do "Véu de Ignorância” (RAWLS, 1971, p.18-19).

Para Rawls, as condições da aceitabilidade universal e da imparcialidade são suficientemente fracas para aparecerem como devidamente justificadas 
para todos os sujeitos concretos aos quais ele se dirige (e aqui é preciso novamente antecipar uma tese a ser defendida mais à frente, a saber, de que a limitação do âmbito dos destinatários da teoria, com suas crenças específicas, não implica subordinação às crenças destes destinatários, mas significa apenas que o trabalho de justificação precisa operar a partir das crenças de algum conjunto de destinatários, consistindo numa espécie de "transcendência desde dentro" destas crenças culturalmente específicas). Mas a vantagem pelo lado da justificação diante dos destinatários equivale a uma desvantagem pelo lado da fundamentação de princípios determinados e interessantes. Para Rawls, tomadas por si sós, as condições da aceitabilidade universal e da imparcialidade não são suficientemente fortes para permitirem a identificação ou construção de princípios bem determinados. É por isso que, na Posição Original proposta em Uma Teoria da Justiça, elas são complementadas por dois outros critérios.

Rawls propõe, em primeiro lugar, um critério referido aos interesses que movem os sujeitos ideais (hipotéticos) que participam da deliberação modelada na Posição Original. De acordo com este critério, os participantes são movidos pelo interesse em ter a maior quantidade possível de "bens primários", entendidos como meios necessários ou úteis para a persecução de quaisquer fins, ou de qualquer concepção de boa vida (RAWLS, 1971, p. 92-93). A partir desse critério, que se associa à característica do desinteresse mútuo dos sujeitos hipotéticos representados na Posição Original, a deliberação destes sujeitos assume a feição de uma escolha daqueles princípios capazes de assegurar-lhes o nível mais satisfatório possível de bens primários. Ora, ao ser configurada pelo Véu de Ignorância como operacionalização da exigência de imparcialidade, a escolha dos sujeitos hipotéticos assume a feição de "escolha racional em condições de incerteza” (RAWLS, 1971, p. 152-156). E disto resulta um segundo critério para complementar as condições da aceitabilidade universal e da imparcialidade: o critério de escolha maximin (em condições de incerteza quanto à probabilidade das diversas situações possíveis, a escolha racional é aquela que focaliza a pior situação possível e procura garantir o melhor resultado nessa situação).

Na obra de 1971, portanto, Rawls propõe o seguinte modelo de exercício da razão prática, orientado para o discernimento de princípios de justiça corretos. Princípios corretos são aqueles que são universalmente 
aceitos ou acordados pelos participantes de uma deliberação justa, ou seja, uma deliberação que resolve de maneira imparcial os conflitos intersubjetivos de interesses, finalidades e pontos de vista. Os participantes (hipotéticos) da deliberação justa estão interessados apenas em garantir para si próprios a maior quantidade possível de bens primários, e não têm interesse ou invejada quantidade alocada aos demais participantes. Ao mesmo tempo, eles ignoram todas as características que, apesar de essenciais na determinação da situação e chances que respectivamente possuem na ordem social concreta, como riqueza socialmente herdada e talentos naturalmente concedidos, devem ser consideradas casuais e irrelevantes no que tange à determinação das normas de justiça. Esta ignorância implica que, apesar de quererem escolher os princípios mais favoráveis a si próprios, sua escolha se realiza em condições de absoluta incerteza. Por isso, os participantes da deliberação justa adotam o critério de escolha maximin. Adotando este critério, eles terminam por estabelecer um acordo em torno dos dois princípios da "justiça como equidade", constitutivos de uma espécie de liberalismo igualitário.

Para o Rawls de 1971, esta proposta atende às duas preocupações por ele focalizadas. Pelo lado da fundamentação dos princípios de justiça, as condições e critérios que estruturam o modelo são suficientemente densos para permitirem o discernimento ou construção de princípios determinados e interessantes. Já pelo lado da justificação da proposta diante dos sujeitos concretos, tais condições e critérios são relativamente delgados ou fracos, eles não exigem dos sujeitos concretos concessões demasiado moralísticas, na medida em que configuram a deliberação justa em termos de escolha racional e auto interessada. E isto significa que o modelo por eles estruturado poderá justificar-se diante dos sujeitos concretos que o teórico procura sensibilizar. Se a tarefa de justificação é antes de tudo uma tarefa de sensibilização dos sujeitos empíricos para as exigências e apelos da razão prática pura, no modelo de 1971 tais apelos recaem, sobretudo, sobre o igualitarismo expresso no "princípio da diferença", contra concepções de justiça menos igualitárias, baseadas numa priorização quer do mérito quer da eficiência social (SCANLON, 2003, p. 156-157). Para o Rawls de 1971, o igualitarismo da "Justiça como Equidade" ia além das convicções sobre a justiça dominantes entre os sujeitos aos quais ele se dirigia, e tratava-se de justificar este apelo moralmente mais denso e 
exigente "equilibrando-o" com concepções grosso modo egoísticas, mais alinhadas às convicções dominantes, e incorporadas no modelo sob a forma da configuração da deliberação justa em termos de escolha racional e auto interessada.

Esta compreensão da tarefa de sensibilização vai se alterar. Para o Rawls de Liberalismo Político (1993 e 1996), o alvo primordial deixa de ser a sensibilização dos sujeitos para um igualitarismo frontalmente contrário a concepções meritocráticas e utilitaristas do valor do ser humano, e passa a ser a sensibilização para os deveres de tolerância, razoabilidade e civilidade em relação a pessoas que abraçam doutrinas sobre o bem contrárias à do sujeito individualmente tomado. Se o modelo de deliberação justa é um modelo de deliberação razoável, no último Rawls a noção de razoabilidade deixa de ser operacionalizada em termos de restrições e exigências impostas à escolha racional e autointeressada, e passa ser operacionalizada em termos de disponibilidade para abrir-se ao ponto de vista do outro, para compreender e até certo ponto anuir às razões do outro. Numa formulação alternativa, a razoabilidade passa a ser apresentada como a capacidade de identificar e utilizar um leque de razões comuns, capazes de promover a aproximação e entendimento entre partidários de doutrinas sobre o bem radicalmente divergentes.

Pode-se discutir até que ponto essa mudança não tornaria dispensável o conceito da Posição Original. Talvez seja possível afirmar que este conceito é logicamente dependente da modelagem da deliberação justa em termos de escolha racional e autointeressada, submetida a determinadas restrições e exigências. Mas não discutiremos esta questão aqui. Partiremos da interpretação mais ortodoxa de que em Liberalismo Político a Posição Original deve ser entendida como um modelo de deliberação entre pessoas perfeitamente (idealmente) razoáveis.

Analisemos agora o conceito do equilíbrio reflexivo. Ao longo de toda sua obra, Rawls mantém a tese de que a justificação da Posição Original diante dos sujeitos concretos realiza-se por meio de equilíbrio reflexivo (RAWLS, 1971, p. 17-22; RAWLS, 1980, p. 533-535; RAWLS, 1996, p. 22-28). Trata-se, mais precisamente, do equilíbrio reflexivo "amplo" e "geral” (RAWLS, 1996, p. 384, nota 16). Três questões são fundamentais para a compreensão das relações entre as noções de "equilíbrio reflexivo", "equilíbrio reflexivo amplo" e "equilíbrio reflexivo geral”. Em primeiro 
lugar, quais são os polos entre os quais se dá o equilíbrio? Em segundo lugar, qual o lugar ou domínio em que se dá o equilíbrio? Em terceiro lugar, em que consiste exatamente o equilíbrio?

Comecemos com o equilíbrio reflexivo tout court. E comecemos com a primeira questão. Com base na análise do equilíbrio reflexivo efetuada por T. Scanlon, pode-se afirmar o seguinte: partindo-se do princípio de que o equilíbrio reflexivo é um método de justificação do modelo proposto pelo teórico, e uma justificação dirigida, fundamentalmente, a cada sujeito concreto ao qual o modelo está sendo proposto, trata-se de um equilíbrio entre os seguintes polos (SCANLON, 2003, p. 139-157). Por um lado, o polo constituído pelas convicções sobre a justiça que em princípio gozam da aceitação e confiança do sujeito concreto ao qual o teórico se dirige. Trata-se de convicções em diferentes níveis de generalidade e âmbitos de aplicação. Podem ser convicções sobre ações e instituições específicas, ou convicções sobre normas mais gerais; pode tratar-se também de convicções sobre o modo justo de resolver conflitos de interesses e pontos de vista, ou seja, sobre as condições de uma deliberação justa (RAWLS, 1996, p. 25-26). O segundo polo consiste no modelo proposto pelo teórico: trata-se de um modelo de exercício da racionalidade prática, que inclui uma representação da deliberação justa e uma representação do resultado desta deliberação, ou seja, dos princípios de justiça que dela resultam, segundo o encaminhamento argumentativo defendido pelo teórico.

A diferença entre o equilíbrio reflexivo tout court e o equilíbrio reflexivo "amplo" refere-se à inclusão neste último de um terceiro polo: modelos de justiça alternativos ou concorrentes, ou seja, representações concorrentes da deliberação justa, ou dos princípios que mais plausivelmente resultariam da deliberação justa. Mas o lugar ou domínio em que se dá o equilíbrio reflexivo amplo é o mesmo em que se dá o equilíbrio reflexivo tout court: a consciência (individual) de cada sujeito concreto ao qual o teórico está se dirigindo. Ora, à medida que o equilíbrio reflexivo amplo alcançado em certa consciência individual é idêntico ao alcançado nas consciências de todos os demais sujeitos concretos aos quais o teórico está se dirigindo, ou seja, à medida que o domínio em que se dá o equilíbrio reflexivo deixa de ser a consciência isoladamente tomada e passa a ser o conjunto dos sujeitos concretos, o equilíbrio reflexivo "amplo" torna-se (também) "geral". 
O parêntese que se apôs ao "também" exprime uma tensão entre os equilíbrios reflexivos "amplo" e "geral". Para ser geral o equilíbrio reflexivo talvez precise ser um pouco mais conservador do que aquele que pode ser alcançado na consciência individualmente tomada; talvez ele precise se prender um pouco mais às convicções sobre a justiça factualmentepredominantes numa dada cultura.

Para compreender e resolver essa tensão, passemos à terceira das questões acima formuladas: em que consiste exatamente o "equilíbrio" do equilíbrio reflexivo? Uma resposta bastante comum corresponde à interpretação coerentista do equilíbrio reflexivo. Com efeito, ao entender a justificação propiciada por este método como uma questão de coerência na rede das crenças vigentes em dada comunidade linguística, a interpretação coerentista sugere que tal rede seja tomada como uma base em última instância dada e inultrapassável. E isto por sua vez sugere que as crenças e atitudes implicadas nessa rede sejam tomadas como pontos de apoio em última instância dados e fixos. Deste ponto de vista, o "equilíbrio" do equilíbrio reflexivo equivaleria a uma espécie de ajuste do modelo proposto pelo teórico às crenças empiricamente vigentes em dada cultura específica; a validade do modelo consistiria simplesmente no fato de que ele propicia maior organização, clareza e sistematicidade argumentativa à rede dessas crenças. Ora, se esta for a interpretação correta do equilíbrio reflexivo rawlsiano, será preciso concluir que Rawls abandona a pretensão de universalidade típica das teorias estritamente cognitivistas. Será preciso concluir, em outras palavras, que ele não pode ser considerado um construtivista pleno. Como vimos no início de nosso trabalho, esta é a opinião de Onora O’Neill.

Thomas Scanlon, entretanto, defende outra interpretação do equilíbrio reflexivo, mais simpática ao cognitivismo forte típico do construtivismo kantiano pleno (SCANLON, 2003, p. 149-153). A partir da interpretação proposta por Scanlon, pode-se afirmar o seguinte: as convicções inicialmente abraçadas pelo sujeito que aprecia a teoria, assim como a rede das mesmas, não devem ser tomadas como uma base em última instância dada, fixa e inultrapassável, mas como o solo sobre o qual opera o trabalho da reflexão racional, entendido como um movimento indefinidamente estendido de "ultrapassagem desde dentro" das crenças sobre a justiça adotadas pela consciência individual, em direção ao ideal de um encontro da 
racionalidade historicamente vigente com a razão prática pura, a perfeita razoabilidade. Ora, este ideal, claramente, abriga a pretensão de validade universal. Mas não se trata de uma ideia já determinada, e nesse sentido já dada, e sim de um ideal a ser paulatinamente definido e redefinido, num processo de aprimoramento da descoberta daquilo que a razão pura exige de nós. Neste sentido, como já foi dito, a ênfase da tarefa de justificação não recai no convencimento dos sujeitos empíricos quanto a princípios definitivamente determinados, mas na sensibilização dos mesmos para as exigências e apelos da razão prática pura. $\mathrm{O}$ equilíbrio reflexivo é um equilíbrio indefinidamente aprimorável.

São úteis aqui duas citações do próprio Rawls.

Com relação ao modo como descobrimos o procedimento correto, o construtivista diz: por reflexão, usando os poderes da nossa razão. Mas como estamos usando nossa razão para descrever a si própria, e como a razão não é transparente a si própria, nós podemos descrever mal nossa razão, como qualquer outra coisa. O esforço para atingir o equilíbrio reflexivo continua indefinidamente (RAWLS, 1996, p. 96-97).

O equilíbrio reflexivo assemelha-se ao teste [de validade moral] de Habermas sob este aspecto: ele é um ponto no infinito que nós podemos nunca alcançar, embora possamos nos aproximar dele, no sentido de que por meio da discussão nossos ideais, princípios e juízos parecem-nos mais razoáveis, e nós os consideramos mais bem fundamentados do que eram antes (RAWLS, 1996, p. 385).

A menção à semelhança com Habermas não deve esconder o fato de que, no quadro da teoria rawlsiana, o fator essencial deste movimento contínuo para atingir a razoabilidade plena consiste na reflexão da consciência individual. $\mathrm{O}$ destinatário primeiro - ou árbitro último - do modelo proposto pelo teórico é a consciência individual (SCANLON, 2003, p. 152-153). Antes de promover uma discussão concreta da consciência individual com outros sujeitos concretos, trata-se para Rawls de promover a discussão ideal da consciência consigo mesma, uma discussão ou diálogo entre a consciência empiricamente condicionada e os apelos da razão pura. É claro que essas duas dimensões da discussão se interpenetram de forma praticamente inextricável, na medida em que a experiência da primeira é essencial à 
segunda. Mas, a nota imediatamente anterior ao texto citado em último lugar deixa claro que, para Rawls, o equilíbrio reflexivo "amplo" (cujo domínio de realização é a consciência individual) é logicamente anterior ao equilíbrio reflexivo "geral" (cujo domínio de realização é o conjunto dos sujeitos concretos) (RAWLS, 1996, p. 384, nota 16).

Podemos retornar agora à tensão acima exposta entre os equilíbrios amplo e geral. Dizer que o destinatário primeiro do movimento reflexivo proposto por Rawls é a consciência individual, ou dizer que o equilíbrio reflexivo amplo é logicamente anterior ao geral - dizer isso não implica afirmar que Rawls não esteja interessado no acordo dos equilíbrios reflexivos individualmente alcançados. Lembremos que o equilíbrio reflexivo é um método de justificação de um modelo de acordo hipotético entre os sujeitos. Embora o acordo seja de início colocado no nível do modelo ideal ou hipotético, e não no nível dos sujeitos concretos que apreciam o modelo, a ideia do acordo reflete-se num interesse de que o equilíbrio reflexivo pelo qual cada indivíduo chancela o modelo ocorra de maneira mais ou menos idêntica em todos os demais indivíduos concretos.

É este interesse que explica os frequentes apelos ao caráter socialmente compartilhado das convicções sobre a justiça envolvidas no equilíbrio reflexivo. Pode-se afirmar que, quando o interesse no acordo dos equilíbrios reflexivos se acentua, Rawls correspondentemente enfatiza o caráter compartilhado das convicções sobre a justiça às quais ele apela. $\mathrm{E}$ isto pode de fato sugerir que tais convicções equivalham a uma base em última instância dada, um fundamento que se coloca além da discussão. Mas, a primazia teórica da consciência individual significa que, embora Rawls também esteja interessado no acordo dos equilíbrios reflexivos, seu interesse primário é o trabalho reflexivo da consciência individual. E isto, por sua vez, significa que as crenças socialmente compartilhadas, longe de constituírem um fundamento além da discussão, constituem o solo de um trabalho reflexivo que as engloba todas num movimento de superação dirigido ao ideal universal da razoabilidade plena.

A tensão entre os equilíbrios amplo e geral atinge em cheio o conceito do consenso sobreposto. É plausível afirmar que tal conceito designa um caso especial de equilíbrio reflexivo geral - trata-se do equilíbrio no qual coletivamente se endossa a modelagem da deliberação justa como deliberação entre sujeitos perfeitamente razoáveis, típica do último Rawls. 
Ora, se o consenso sobreposto deve ser interpretado como um caso de equilíbrio reflexivo geral, a interpretação da tensão acima defendida implica que tal conceito deve ser entendido como um consenso logicamente subordinado à dinâmica reflexiva da consciência individual e à perfectibilidade contínua envolvida nesta dinâmica; subordinado, portanto, ao ideal de um encontro da racionalidade empiricamente condicionada com as exigências da razoabilidade plena. O consenso sobreposto não é um consenso concreto entre sujeitos empiricamente dados, baseado numa coincidência feliz (mas contingente) das convicções historicamente dadas numa cultura específica. Trata-se antes de um consenso entre sujeitos inseridos numa dinâmica reflexiva dirigida a um ideal, retratados como indivíduos que, apesar de compreenderem suas vidas e esforços pessoais segundo as valorações fortes típicas das doutrinas abrangentes do bem, e apesar de adotarem doutrinas diferentes e eventualmente conflitantes, compreendem-se simultaneamente como sujeitos dotados da capacidade de separar as questões sobre a boa vida das questões sobre a justiça. Em outras palavras, o consenso sobreposto é um consenso entre sujeitos atingidos pelos apelos de razoabilidade propostos pelo teórico, sujeitos que aceitam a tese de que, no âmbito das relações estritamente públicas ou políticas, considerações de justiça devem ter prioridade sobre as concepções do que é importante e valioso na vida pessoal (RAWLS, 1996, p. 388).

Num contexto em que o modelo a ser reflexivamente endossado consiste no ideal de uma deliberação entre sujeitos perfeitamente razoáveis, pode-se afirmar o seguinte a respeito dos equilíbrios reflexivos que são buscados e esperados: embora seja plausível esperar que o equilíbrio reflexivo "amplo" seja também "geral", no sentido de concordante para todos os sujeitos concretos aos quais o trabalho reflexivo está sendo proposto, os caminhos para se chegar a este resultado serão admitidamente diferentes, em virtude das divergências nas convicções iniciais dos sujeitos que abraçam diferentes doutrinas abrangentes. E isto significa, como afirmado acima, que o equilíbrio reflexivo geral terá o caráter de um “consenso sobreposto" entre partidários (finitamente) razoáveis de diferentes doutrinas abrangentes. $\mathrm{O}$ consenso sobreposto exprime a concordância de resultado de diferentes caminhos de equilíbrio reflexivo (amplo).

Ora, admitindo-se que o consenso sobreposto equivale à concordância de resultado dos equilíbrios reflexivos amplos alcançados, alcançáveis e 
indefinidamente aprimoráveis por pessoas (finitamente) razoáveis, ou seja, pessoas atingidas pelos apelos de razoabilidade propostos pelo teórico; admitindo-se, em segundo lugar, que este último tipo de equilíbrio reflexivo, à semelhança de todos os demais tipos, pode manter a pretensão de validade universal do ideal da razão prática pura (ainda que este ideal só exista na relação dialética com um polo oposto, constituído pelas convicções empíricas a serem reflexivamente trabalhadas e superadas); admitindo-se então estes pontos, pode-se concluir que os conceitos rawlsianos de equilíbrio reflexivo e consenso sobreposto são plenamente compatíveis com o cognitivismo forte típico do construtivismo kantiano.

Restaria analisar uma última questão. Até que ponto tais conceitos atendem à ambição internalista típica do construtivismo pleno? Até que ponto a teoria rawlsiana pode sustentar a tese de que os princípios justificados (ou justificáveis) no "consenso sobreposto" são intrinsecamente motivadores para sujeitos razoáveis finitos? Até que ponto a reflexão envolvida no ideal de um consenso sobreposto universal pode ser considerada intrinsecamente motivadora para os sujeitos finitos? Como fundamentar a autoridade motivacional dos princípios reflexivamente endossados, ou reflexivamente justificáveis? A análise dessas questões fica adiada para outra oportunidade.

\section{Referências bibliográficas}

1980. Kantian Constructivism in Moral Theory. The Journal of Philosophy, v. 77, n. 9, p. 515-572, September 1980.

1996. Political Liberalism. Paperback Edition. New York:

Columbia University Press. 1998. What We Owe to Each Other. Cambridge,

Massachusetts: Harvard University Press. 2003. Rawls on Justification. In: FREEMAN, S. (Ed.)

The Cambridge Companion to Rawls. New York: Cambridge University Press. 
1999. Verdade e Justificação. Ensaios Filosóficos.

Tradução de Milton Camargo Mota. São Paulo: Loyola, 2004.

HABERMAS, J. 1996. The Inclusion of the Other: Studies in Political Theory. Tradução de Ciaran Cronin. Cambridge, Massachusetts: MIT Press, 1998.

McCARTHY,T. 1994. Kantian Constructivism and Reconstructivism: Rawls and Habermas in Dialogue. Ethics, University of Chicago, n. 105, p. 44-63, October 1994.

O'NEILL, O. 2003. Constructivism in Rawls and Kant. In: FREEMAN, S. (Ed.). The Cambridge Companion to Rawls. New York: Cambridge University Press.

RAWLS, J. 1971. A Theory of Justice. Cambridge, Massachusetts: Harvard University Press.

SCANLON, T. 1982. Contractualism and Utilitarianism. In: SEN, A.; WILLIAMS, B. (Eds.) Utilitarianism and beyond. Cambridge: Cambridge University Press.

TUGENDHAT, E. 1983. Propedêutica Lógico-Semântica. Tradução de Fernando Rodrigues. Petrópolis:Vozes, 1996. 
0 0 


\title{
Justiça como Equidade e o Problema da Razoabilidade
}

\author{
Denis Coitinho Silveira \\ deniscoitinhosilveira@gmail.com \\ Universidade do Vale dos Sinos (UNISINOS), São Leopoldo, Brasil
}

resumo Neste artigo eu quero mostrar a importância do conceito de razoável na teoria da justiça como equidade, de John Rawls e, também, quero explicar o problema da razoabilidade nessa teoria. 0 ponto de partida será ressaltar a exigência de razoabilidade que é feita ao agente moral na justiça como equidade. Posteriormente, procurarei identificar algumas críticas a esse critério. Partirei da crítica formulada por Estlund a respeito do estreitamento do conceito de razoabilidade e a necessidade da verdade e das críticas estabelecidas por Timmons e Gaus sobre a exigência demasiada e ineficaz da razoabilidade. 0 passo seguinte será tentar responder a essas críticas formuladas e, na parte final do texto, procurarei estipular um argumento a respeito de um tipo de responsabilidade moral razoável que pode estar contida na justiça como equidade.

palavras-chave Equidade; Razoabilidade; Limites da razão; Limites do juízo; Responsabilidade; Rawls

Qual é a exigência adequada que se pode fazer a um agente moral? Que ele saiba todos os critérios morais, como princípios e virtudes, que devem ser aplicados ao caso, de forma que ele conheça esse critério como verdadeiro, isto é, correspondente a um certo estado de coisas? Ou, alternativamente, bastará que ele oriente sua ação a partir de suas convicções morais mais profundas? O que uma teoria normativa pode exigir factivelmente de um sujeito moral, de forma que essa exigência seja eficiente, isto é, que 
ela realmente obrigue o sujeito a fazer a ação X ou Y? Ela pode exigir o conhecimento de um critério último de justificação das crenças morais, bem como de um ponto arquimediano, ou ela apenas pode sugerir que o sujeito revise suas convicções quando em uma situação de conflito? Qual seria a dose adequada de exigência?

Como se pode facilmente perceber, as respostas dadas às questões anteriormente formuladas ou recaem sob um modelo fundacionalista de justificação ou sob um modelo epistêmico-moral contextualista. Mas, será que nossas opções se restringem apenas a essas duas? Não seria possível encontrar um modelo intermediário que nem exigisse do agente o conhecimento último do critério moral e nem se contentasse apenas com a revisibilidade de suas crenças? Creio que podemos encontrar essa posição intermediária na teoria da justiça como equidade de John Rawls. O argumento central dessa teoria parece ser o de que, de um ponto de vista social (social point of view), se pode chegar a um consenso do que contará como tendo um valor moral público de uma forma independente das crenças privadas de bem, de forma que se vão construir princípios morais políticos (de igual liberdade, igualdade equitativa de oportunidade e diferença) a partir dos próprios valores morais reconhecidos socialmente em uma sociedade democrática do tipo contemporânea e, então, a estratégia será testá-los por (i) sua coerência com os pontos fixos dos juízos morais ponderados (considered judgments) em todos os níveis de generalidade e (ii) por seu resultado quando aplicado às instituições democráticas, isto é, por sua garantia de estabilidade pelas razões corretas (stability for the right reasons) que conduz à legitimidade política (political legitimacy), o que é outra forma de dizer que eles serão testados por um equilíbrio reflexivo (reflective equilibrium) amplo (wide) e geral (general), sendo a justificação concebida em um equilíbrio reflexivo pleno $(f u l l)^{1}$.

O ponto de partida, então, é o que já é aceitável socialmente, isto é, os próprios valores morais políticos que são assumidos pelos cidadãos de uma democracia contemporânea, tais como: razoabilidade, reciprocidade, tolerância, civilidade, cooperação etc., valores esses que serão usados no procedimento de construção da posição original (original position. Isto é demonstrado pelo papel central que a ideia normativa de sociedade como um sistema equitativo de cooperação social desempenha no procedimento, que implica nas ideias normativas de pessoas como livres e iguais e 
sociedade bem ordenada, ideias essas que estarão pressupostas no procedimento de deliberação das partes (parties) sob as restrições do véu da ignorância (veil of ignorance) e circunstâncias da justiça (circumstances of justice) para a construção/escolha dos princípios morais e o teste pelo equilíbrio reflexivo. Nas palavras de Rawls:

Reunimos as convicções arraigadas, como a crença em tolerância religiosa e a rejeição da escravidão e tentamos organizar as ideias e princípios básicos implícitos nessas convicções numa concepção política de justiça coerente. Tais conviç̧ões são pontos fixos provisórios que parece que qualquer concepção razoável deve levar em conta. Começamos, então, observando a própria cultura pública como fundo compartilhado de ideais e princípios básicos implicitamente reconhecidos. (RAWLS, 1996, p. 8)².

Veja-se que o que essa teoria normativa exige do sujeito moral será uma disposição de propor e cumprir os termos equitativos de cooperação, como já vimos anteriormente e, também, uma disposição para reconhecer os limites da razão em justificar arquimedianamente os juízos morais proferidos pelos indivíduos, isto é, ela exigirá o reconhecimento da sobrecarga da razão (burdens of reasons), o que é uma outra forma de dizer que ela exigirá que o sujeito moral seja razoável (reasonable). Mas, o que isso significa? Que o sujeito deve se dispor a partir da ideia de sociedade equitativa para o estabelecimento do critério moral público porque já faz uso da ideia de reciprocidade. Que ele deve se dispor a reconhecer o fato do pluralismo razoável e o fato da opressão, que é igual a reconhecer a existência de várias convicções morais sobre o bem em sociedades complexas contemporâneas como uma característica permanente e, também, que a única forma de alcançar uma unidade moral absoluta seria pelo uso da força do Estado para obrigar todos os sujeitos a aceitar uma mesma concepção de bem³ ${ }^{3}$. Esse parece ser um posicionamento de aceitação da falibilidade humana em alcançar a justificação absoluta de suas crenças morais e, por isso, não exige do sujeito moral o conhecimento do critério último de justificação, isto é, sua verdade. Antes, trata-se de uma tentativa de aplicar o conceito de tolerância à própria filosofia moral. Dessa forma, a razão é deflacionada, no sentido que ela terá uma capacidade limitada para alcançar a justificação. A exigência de razoabilidade (reasonableness) é explicada nesses termos por Rawls: 
O primeiro aspecto básico do razoável é, portanto, a disposição de propor termos equitativos de cooperação e cumpri-los, desde que os outros também o façam. O segundo aspecto básico, como agora revejo, é a disposição de reconhecer os limites do juízo e aceitar suas consequências para o uso da razão pública na condução do exercício legítimo do poder político em um regime constitucional (RAWLS, 1996 , p. 54) ${ }^{4}$.

Por ser uma disposição, a ação razoável ou a razoabilidade está sendo tomada como uma virtude necessária ao agente moral para sua deliberação, pois exigirá do agente uma disposição moral de agir a partir do critério de reciprocidade e uma disposição intelectual de reconhecimento da limitação racional. Por outro lado, é importante frisar que a justiça como equidade não se contentará com apenas uma exigência mínima de revisibilidade das crenças por parte do indivíduo, embora essa característica seja de fundamental importância nesse modelo coerentista holístico e pragmatista de justificação. É por esse motivo que os procedimentos ocupam um papel central para a justificação da norma, de forma a exigir, também, o reconhecimento de determinados fatos que podem contar como razões no procedimento ou da posição original - equilíbrio reflexivo ou do consenso sobreposto (overlapping consensus). Mas, que fatos contam como uma razão no procedimento? As crenças que são justificadas intersubjetivamente, isto é, que podem ser tomadas como fatos sociais (institucionais). Por exemplo: que a cooperação é boa socialmente, que as pessoas são morais, isto é, livres e iguais, que a exigência de reciprocidade é uma boa medida para a resolução de conflitos. Esses fatos não dependem da aprovação de um indivíduo isolado, mas requerem uma aprovação social que, inclusive, pode ser percebida em uma dimensão histórica ${ }^{5}$.

Procurei mostrar acima como o critério de razoabilidade parece central para o projeto de Rawls. Mas, pode uma teoria normativa de justiça prescindir do conceito de verdade para a justificação, contentando-se apenas com o critério de razoável? Não se perderia toda a normatividade com esse movimento e a recaída no relativismo seria inevitável? Ou, alternativamente, não seria demasiado e ineficaz exigir a razoabilidade do agente moral, uma vez que exigiria um tipo de conhecimento que o agente moral comum não tem acesso ou, no limite, que as pessoas são absolutistas 
e não razoáveis em seus juízos cotidianos? No restante desse artigo procurarei responder a essas questões. Partirei da crítica formulada por Estlund a respeito do estreitamento do conceito de razoabilidade e a necessidade da verdade e das críticas estabelecidas por Timmons e Gaus a respeito da exigência demasiada e ineficaz da razoabilidade. Posteriormente, tentarei responder a essas críticas formuladas e, na parte final do texto, procurarei formular um argumento a respeito de um tipo de responsabilidade moral razoável que pode estar contida na justiça como equidade.

\section{II}

Deixem-me iniciar com a crítica de Estlund feita no artigo "The Insularity of the Reasonable", que afirma que a justiça como equidade deve admitir a verdade, sendo o critério de razoabilidade ou aceitabilidade limitado para garantir a justificação dos princípios morais em razão de seu modelo de legitimação não ser defensável por sua incompletude. Isso porque a tese central do Liberalismo Político é afirmar princípios morais políticos de tolerância no âmbito da justificação pública que não precisam ser verdadeiros. Isso implica que mesmo doutrinas verdadeiras são inadmissíveis a menos que elas sejam aceitas por todos os cidadãos razoáveis. Estlund vê acertadamente, então, que a verdade não é nem condição necessária e nem suficiente para a admissibilidade das doutrinas abrangentes:

A ideia moral por trás desse princípio é que nenhuma pessoa pode legitimamente ser coagida ou moralmente obrigada a seguir normas legais e obrigações a menos que razões suficientes possam ser dadas que não violem as convicções morais e filosóficas razoáveis das pessoas sobre o verdadeiro ou falso, certo ou errado. (ESTLUND, 1998, p. 253).

$\mathrm{O}$ argumento que Estlund parece defender é que se esse princípio sobre justificação é ele próprio oferecido como parte da justificação pública, ele, então, se aplica a si mesmo. Segue daí que ele deve ser aceitável para todos os cidadãos razoáveis e não pode ser invocado como verdadeiro, nem mesmo a própria concepção de razoabilidade. A tese parece afirmar que esse modelo de justificação pública deve afirmar a verdade e não apenas a razoabilidade de seu princípio fundamental, a saber, a ideia de que 
doutrinas são admissíveis como premissas na justificação pública somente se forem aceitáveis para todos os cidadãos razoáveis. Embora um tanto diferente da crítica já bem conhecida feita por Raz, em razão de fazer uma conexão correta entre justificação e legitimidade, também afirmará que uma teoria política normativa não pode pairar acima da verdade moral, sem qualquer ponto de contato ${ }^{6}$.

Seu argumento central é apresentado com a seguinte formulação intitulada de RAN (Reasonable Acceptance Necessary): "Nenhuma doutrina é admissível como uma premissa em qualquer estágio da justificação política a menos que ela seja aceitável para todos os cidadãos razoáveis, e não necessita ser aceitável para mais ninguém." (ESTLUND, 1998, p. 254). Entendendo o termo "doutrina” de forma a significar declarações factuais, princípios, propostas e mesmo juízos morais, RAN, assim, é ela própria uma doutrina. A questão, então, é a de que essa doutrina não precisa ser verdadeira, mas apenas aceitável por todos. A crítica de Estlund é que a razoabilidade, que é a aceitabilidade de todos, deve ela própria ser verdadeira, ou, então, essa doutrina seria arbitrária e os indivíduos não precisariam se ver obrigados a segui-la. O problema aqui é que RAN é aplicada a ela mesma, sendo ela própria uma premissa na justificação pública. O ponto central nessa argumentação é mostrar que Rawls deveria considerar a questão de que seu princípio liberal de legitimidade deveria ser tomado como verdadeiro. Sumarizando o argumento de Estlund até o momento, temos: dado que Rawls quer aplicar o princípio da tolerância à própria filosofia, a justiça como equidade aplica o princípio de tolerância nela própria e, dessa forma, deveria afirmar o requisito de tolerância também como verdadeiro. A conclusão é a de que uma concepção política alternativa de justiça, ao reivindicar sua verdade, seria substantiva e, logo, não dogmática (ESTLUND, 1998, p. 256).

O próximo passo será o da apresentação de uma versão modificada de RAN, com o interesse de investigar a questão independentemente do conteúdo da ideia de razoabilidade. Assim, AN (Acceptance Necessary): "Nenhuma doutrina é admissível como premissa em qualquer estágio da justificação política a menos que ela seja aceitável por um certo conjunto de cidadãos (reais ou hipotéticos), C, e nada mais que a aceitação é necessário." (ESTLUND, 1998, p. 257). Aqui o ponto será o de mostrar que AN afirma uma condição necessária, mas que não é suficiente para 
a admissibilidade. Como Rawls sustenta que a razoabilidade é suficiente para a justificação, evitando a pretensão de verdade, o problema é que quando uma certa versão de $\mathrm{C}$ é posta à frente de outras versões alternativas possíveis em $\mathrm{AN}$, parece não haver critérios seguros para sustentar que essa seja uma versão correta de C.A conclusão parece clara: não é possível uma escolha não arbitrária dos possíveis conteúdos de $\mathrm{C}$ nas relações entre este e as diferentes instâncias de AN que não viole sob algum aspecto a pretensão da não necessidade da verdade para a justificação pública (ESTLUND, 1998, p. 261-263).

A proposta de Estlund é a de que a teoria de Rawls deve tomar RAN como verdadeira, estabelecendo contato com a verdade, ao menos em um sentido mínimo. O critério deve ser modificado da seguinte forma: MAC (Modified Acceptance Criterion):

Como exceção dessa doutrina, nenhuma doutrina é admissível ou excluída como uma premissa na justificação política sobre as bases de sua verdade ou falsidade, mas é admissível apenas quando e porque ela é aceitável para todos os cidadãos razoáveis (...). A presente doutrina deve ser aceitável para todos os cidadãos e verdadeira. (ESTLUND, 1998, p. 266).

É importante procurar compreender qual é mudança realizada aqui.Vejase que o critério de aceitabilidade/razoabilidade continua como uma condição necessária para a justificação pública, pois o que vai justificar qualquer doutrina abrangente é sua aceitabilidade social. Por outro lado, essa doutrina da aceitabilidade deve ser ela própria aceitável e verdadeira; sendo ela verdadeira, então, também é condição suficiente para a justificação. Com a afirmação da verdade dessa premissa liberal, então, juízos morais razoáveis podem ser tomados como verdadeiros. O que Estlund parece ter em mente é que a noção de verdade que deve ser utilizada não pode ir além de um sentido mínimo: "Para qualquer declaração $\mathrm{P}$, P é verdadeiro no sentido mínimo se e somente se P". Por exemplo, se todos podem aceitar que assassinar é errado, então, "assassinar é errado" é verdadeiro no sentido mínimo requerido pelo liberalismo político. A conclusão a que ele chega é a seguinte: para uma teoria da legitimação ser defensável, ela precisa ir além dessa dimensão prática de aceitabilidade como critério de justificação e refletir e posicionar-se sobre sua verdade (ESTLUND, 1998, p. 270-275) ${ }^{7}$. 
Mas há, também, um outro tipo de crítica ao papel do critério de razoabilidade na justiça como equidade que acentua, não a sua fraqueza, mas a sua excessividade. Essa é a constatação central de Timmons, a saber, que teorias morais ao estilo da proposta por Rawls exigem em demasia do agente moral, pois exigem uma disposição para o reconhecimento dos limites da razão. Alternativamente, ele situará a responsabilidade do agente em um âmbito mais modesto, que será o de (i) obter evidência, (ii) lidar e considerar as possibilidades alternativas e (iii) lidar com conflitos internos de crenças (TIMMONS, 2004, p. 195) ${ }^{8}$.

Vejam-se as razões disso.Timmons está comprometido com um modelo de epistemologia moral contextualista, propondo uma justificação doxástica da crença moral, uma vez que a maior parte das crenças éticas comuns podem ser justificadas pela responsabilidade epistêmica do agente, o que implica em avaliar as situações alternativas. Sua tese central é que se pode ser responsável epistemicamente em assegurar certas crenças sem necessitar de justificação para elas, bastando a avaliação das crenças de primeira ordem por parte do agente, o que envolve parâmetros variáveis como: objetivo, perspectiva e recursos. Para ele, não é necessário estar engajado em uma aceitação de uma teoria moral para um indivíduo estar doxasticamente justificado em assegurar uma crença moral particular. Ao contrário, defende que as crenças doxasticamente justificadas devem ser justificadas proposicionalmente por um indivíduo, o que não implica assumir que essa justificação se dará pela coerência com um princípio moral. O problema desse modelo coerentista, como o de Rawls, é que ele não se encaixa com as deliberações morais cotidianas, pois os indivíduos não escolhem princípios entre teorias morais primeiro para só depois verificar se suas crenças estão corretas. Dessa forma, a regra da responsabilidade epistêmica contextualista é formulada da seguinte maneira por Timmons:

Normalmente, uma pessoa S é responsável epistemicamente em acreditar em algumas proposições $\mathrm{p}$ ao tempo $\mathrm{t}$ apenas se $\mathrm{S}$ checar todas as possibilidades alternativas que seriamente estão indicadas por um adequado conjunto de crenças de fundo em t. (TIMMONS, 2004, p. 200). Qual é o problema aqui? A questão é que Timmons está se contrapondo ao coerentismo que exige que o agente possua uma bateria muito grande de crenças: crenças de primeira ordem, tanto crenças morais como não morais, e crenças de segunda ordem, que são crenças para a justificação das 
primeiras. Sua proposta se pretende menos exigente, uma vez que defende o conservadorismo das crenças de segunda ordem sobre as crenças contextualmente básicas, sendo as crenças de primeira ordem justificadas se asseguradas responsavelmente pelo agente. Assim, algumas crenças morais, especialmente as que são parte constitutiva de nossa perspectiva moral, servem como um corpo de assunções morais básicas que, em contextos comuns de pensamento e discussão moral, não precisam de justificação (TIMMONS, 2004, p. 213).

$\mathrm{Na}$ justiça como equidade, o reconhecimento dos limites racionais, que é o mesmo que razoabilidade, se constitui como crenças de segunda ordem que terão o papel de julgar a validade das crenças de primeira ordem. Como a legitimidade da coerção do poder político é dada pela aceitabilidade das crenças feitas por pessoas razoáveis, a legitimidade é alcançada pela razoabilidade/aceitabilidade, sendo ela o próprio critério de justificação. Um problema que poderia estar relacionado com a crítica de Timmons de uma exigência demasiada seria o de questionar se as pessoas não razoáveis teriam a sua autonomia política desrespeitada pelo método de legitimação/justificação de Rawls? Será que a justiça como equidade não infringiria os direitos básicos e liberdades dos indivíduos não razoáveis? Seria isto justo, uma vez que no mundo real as pessoas geralmente não são razoáveis??

A constatação de que as pessoas não são de fato razoáveis pode servir, também, para ressaltar a ineficiência do critério de razoabilidade para a justificação. Esse parece ser o argumento apresentado por Gaus ao estabelecer uma crítica à ideia de justificação pública de Rawls, que estaria baseada no critério de razoabilidade, implicando em uma teoria populista do raciocínio prático, pois deve contar com um assentimento das pessoas para a justificação (GAUS, 1996, p. 130-131). Qual a estratégia empregada por Gaus? Parece ser a de mostrar a fraqueza desse critério de razoabilidade, que indicaria uma disposição para propor e seguir os princípios que podem ser publicamente justificados; para reconhecer os limites do juízo; para raciocinar corretamente; para fazer raciocínios acessíveis aos outros, fazendo uso de argumentos de bom senso e conclusões não controversas da ciência. O problema é que, para Gaus, as pessoas não são razoáveis, apresentando três razões para comprovar sua tese: (i) falácia do jogador, que mostra que as pessoas podem ser induzidas a abandonar 
normas válidas de inferência e cometer erros em juízos probabilísticos; (ii) akrasia epistêmica, que revela que as pessoas não tem disposição para aceitar os argumentos de bom senso e as provas científicas; (iii) juízos absolutistas, que aponta que as pessoas geralmente proferem seus juízos com certeza absoluta, o que não encaixa com a exigência dos limites dos juízos e com a condição de acessibilidade ${ }^{10}$. Os três exemplos revelam um mesmo argumento: as pessoas reais não são razoáveis no seu cotidiano, logo, a razoabilidade não é suficiente para a justificação, devendo ser substituída pela racionalidade, colocando a vitória de uma crença sobre outra no lugar do acordo (GAUS, 1996, p. 131-136).

\section{III}

Agora, procurarei responder a essas objeções. A respeito da crítica de Estlund sobre a necessidade do critério de razoabilidade ser verdadeiro a fim de resultar em uma concepção de legitimação adequada, inicio ressaltando uma característica central do modelo de justificação defendido por Rawls: ele quer superar os modelos dicotômicos em filosofia moral que estabelecem uma distinção radical entre uma esfera factual e outra normativa, procurando estabelecer uma relação de complementaridade entre valores e fatos, o que fica evidenciado pelo papel do método do equilíbrio reflexivo, que tem a tarefa de organizar nossos juízos morais ponderados de forma a servirem de base para a construção dos princípios, o que possibilita uma concepção moral coerente (RAWLS, 1971, p. 579; RAWLS, 1999, p. 507). Após essa observação geral, gostaria de precisar o que eu estou dizendo: que a tentativa de Rawls de superação da dicotomia fato/ valor o levará a adotar uma estratégia pragmatista de justificação - justificação é uma questão prática antes que teórica. Assim, a própria noção de razoabilidade dentro da justiça como equidade tem, ela própria, uma dimensão prática e não teórica, isto é, ela não é tomada como um critério último que estaria descolado de toda a realidade, mas, preferencialmente é um ideal político e, por essa razão, é estipulada como condição necessária e suficiente para a justificação. Nas palavras de Rawls:

Observe que aqui ser razoável não é uma ideia epistemológica (embora tenha elementos epistemológicos). Preferencialmente, ela é parte de 
um ideal político de cidadania democrática que inclui a ideia de razão pública (RAWLS, 1996, p. 62) ${ }^{11}$.

Veja-se que a crítica de Estlund é que a razoabilidade não poderia ser uma condição suficiente para justificação, sendo apenas condição necessária, uma vez que garantir a legitimidade pela pura aceitabilidade poderia recair em arbitrariedade. Por isso, sua proposta é a de tomar esse princípio da aceitabilidade como minimamente verdadeiro, na forma "Para qualquer declaração P, P é verdadeiro se e somente se P". Mas, essa acusação é procedente? Creio que não. E a razão para defender essa posição é que o critério de razoabilidade, mesmo não sendo verdadeiro, serve para a justificação pública, o que implicará na afirmação de valores morais-políticos de forma freestanding, isto é, valores que se sustentam sozinhos na esfera política, por meio do procedimento da posição original, que é normativo.Veja-se que esses valores são tomados como aquilo que é assumido socialmente, ou, dito de outra forma, esses valores proporcionam uma "base satisfatoriamente compartilhada de justificação pública."12 (RAWLS, 1989, p. 485).

Essa estratégia pode ser vista como uma tentativa de procurar estabelecer o valor em coerência com o fato, isto é, de relacionar os valores morais-políticos com as práticas sociais, políticas e econômicas de sociedades democráticas contemporâneas com diversidade moral. É por isso que para estabelecer a justificação dos princípios de justiça se precisará de uma justificação pública, o que implicará em ver se eles garantirão estabilidade social e legitimidade política. Aqui a tese parece ser que o que contará para a legitimação será o mesmo que o que valerá para a justificação. É por isso que o consenso é aquilo que tanto garante a legitimidade do uso do poder político quanto assegura a validade da norma (RAWLS, 1971, p. 580; RAWLS, 1999, p. 508; RAWLS, 1996, p. $136)^{13}$. Assim, a tarefa real de justificar uma concepção de justiça não é primordialmente um problema epistemológico:

A busca por fundamentos razoáveis para alcançar um acordo enraizado em nossas concepções de nós mesmos e em nossa relação com a sociedade substitui a busca pela verdade moral interpretada como fixada por uma ordem anterior e independente de objetos e relações, naturais ou divinas, uma ordem aparte e distante de como nós nos concebemos. (RAWLS, 1980, p. 306) ${ }^{14}$. 
Seria esse modelo de justificação arbitrário? Penso que não. Isso porque os princípios de justiça aceitos com base em nossas convicções morais mais profundas podem ser testados tanto por um procedimento formal de simetria na deliberação quanto por um procedimento pragmático de estabilidade e legitimidade. É verdade que não se conta com um critério último que pairaria fora do mundo; entretanto, a norma está sendo estipulada porvalores sociais que vem obtendo aceitação nas próprias práticas e são validados por procedimentos. A normatividade é factual-procedimental. A concepção alternativa de Estlund, por sua vez, diz que acabaria com a arbitrariedade em razão do uso de uma concepção mínima de verdade. Será mesmo? Vejamos o exemplo dado por ele: se todos podem aceitar que assassinar é errado, então, "assassinar é errado" é verdadeiro no sentido mínimo exigido pelo liberalismo político. Qual a diferença em relação à justiça como equidade até aqui? Parece que nenhuma, uma vez que o argumento é o mesmo: se todos podem aceitar que a intolerância religiosa e a discriminação racial são injustas com uso do(s) procedimento(s), então, a "intolerância religiosa" e a "discriminação racial" são injustas e, sendo injustas, não devem ser praticadas ${ }^{15}$. Note-se que esta estratégia procedimental parece possuir o mesmo peso que uma concepção minimalista de verdade. Isso porque uma concepção minimalista não pressupõe a existência de uma ordem de coisas independente dos sujeitos que serviriam de critério para saber se o dito corresponderia ou não a essa ordem de coisas; entretanto, possibilita que o juízo moral seja tomado como objetivo. É esta concepção de verdade representacionalista que está sendo recusada por Rawls e não uma concepção deflacionada de verdade que, inclusive, é adequada a um modelo coerentista e pragmatista de justificação ${ }^{16}$. Penso que não é muito elucidativo uma inflação demasiadadessa distinção entre o razoável e o verdadeiro, uma vez que a razoabilidade pode ser tomada como uma verdade prática, isto é, como uma convergência prática social. Se Estlund parece também recusar essa concepção tradicional de verdade, não compreendo, então, qual a forte distinção entre o que ele está propondo e o que é defendido por Rawls. E assim, porque apenas o modelo rawlsiano seria arbitrário? Não seria essa posição ela própria arbitrária?

E o que dizer da outra objeção a respeito da exigência da razoabilidade do agente moral? Seria ela excessiva e ineficaz, uma vez que o agente moral comum parece não possuir esse critério metajustificatório para a 
validação de suas crenças, isto é, crenças de segunda ordem? Retomemos a explicação do que é razoabilidade para Rawls com a finalidade de identificar seu conteúdo específico. Com isso em mãos, pretendo mostrar que essa exigência não é demasiada, mas, ao contrário, é uma exigência comum que se faz a qualquer cidadão de uma sociedade democrática contemporânea.

Em primeiro lugar, razoabilidade é uma disposição para propor e cumprir os termos equitativos de cooperação e, sendo assim, é compreendida como uma faculdade moral que capacita o agente a propor e depois motivar-se a agir em conformidade com os termos equitativos de cooperação por seu valor intrínseco. Isto quer dizer que a razoabilidade é uma virtude social que é pressuposta pela justiça como equidade (RAWLS, 1996, p. 54). Explicando mais detalhadamente essa virtude moral social, temos que a razoabilidade: (i) é parte da sensibilidade moral; (ii) está conectada com a ideia de reciprocidade, que é intermediária entre o altruísmo e o egoísmo; (iii) não é derivada da racionalidade; (iv) é pública, de forma que garante a igualdade entre as pessoas no âmbito do reconhecimento social (RAWLS, 1996, p. 48-54).

Em segundo lugar, razoabilidade é a disposição para reconhecer os limites do juízo e da razão e aceitar suas consequências para o uso público da razão na condução do exercício legítimo do poder político em um regime democrático constitucional (RAWLS, 1996, p. 54). Já vimos que isso implicará em reconhecer o (i) fato do pluralismo razoável, isto é, reconhecer como legítima a diversidade moral que obedece a restrição do razoável e o (ii) fato da opressão, que é a compreensão que só com um Estado forte e opressivo se garantiria a unidade moral. Essa é uma exigência intelectual, uma vez que o indivíduo deve compreender a realidade em que vive, identificando que nem toda a pessoa razoável defende a mesma doutrina abrangente e, logo, não é possível que todas essas doutrinas sejam verdadeiras. Também, isso implicará em endossar alguma forma de liberdade de consciência e autonomia de pensamento. Pode-se perceber, então, que esse reconhecimento dos limites do juízo é fundamental para a ideia democrática de tolerância. A esse respeito, é importante fazer referência a essa observação de Rawls:

Não é realístico - ou pior, isto desperta suspeita mútua e hostilidade

- supor que todas as nossas diferenças estão enraizadas apenas na 
ignorância e perversidade, ou ainda, em rivalidades pelo poder, status ou ganho econômico. (RAWLS, 1996, p. 58) ${ }^{17}$.

De posse desse conteúdo da razoabilidade, se pode agora tentar responder a objeção de Timmons, usando o seguinte argumento: não é uma exigência demasiada a um agente moral porque não é uma exigência demasiada a um cidadão de uma democracia constitucional, uma vez que o agente moral é um cidadão. É legítimo exigir que um cidadão aja de forma racional e razoável, isto é, que deva fazer uso de juízos, inferências e pensamento e, também, que aja a partir de um senso moral adequado. Um agente moral é uma pessoa. Uma pessoa tem capacidade de senso de justiça (razoabilidade) e concepção de bem (racionalidade). Isso quer dizer que os agentes devem ter essas duas capacidades (de pessoa) num grau mínimo que lhe permitam sercidadãos livres e iguais em um regime constitucional e, assim, a exigência é legítima (RAWLS, 1996, p. 61-62).

Quero chamar atenção para o seguinte fato: não há uma grande celeuma a respeito de serem demasiadas as exigências que se fazem aos cidadãos reais em comunidades reais. Vemos como legítimas as exigências de ter que obedecer às leis, como as encontradas na constituição, código penal, código civil e outros códigos socialmente reconhecidos. Se alguém estuprar ou sequestrar uma pessoa e for presa e acusada por esse ato, não servirá de desculpa o fato dela não saber que isso era proibido por lei. Nem no caso da pessoa não saber ler ou ter passado um período em coma. Isso quer dizer que exigimos dos cidadãos que eles obedeçam ao que a lei determina e, além disso, que eles se conduzam de certa forma moral, isto é, de certa forma imparcial ou que respeita a reciprocidade, que é o mesmo que dizer que os cidadãos devem ser civilizados, podendo conviver harmoniosamente com os outros. O que é isso senão exigir o reconhecimento dos limites dos juízos e da razão? Agora, se não é demasiado para os cidadãos comuns, por que seria uma exigência demasiada para o agente moral?

A crítica de Timmons é que a exigência do reconhecimento dos limites da razão implica no conhecimento de uma crença de segunda ordem que possibilitará a justificação das crenças de primeira ordem. Creio que isso seja um engano ao menos parcialmente, pois Rawls procura deixar claro que esse reconhecimento dos limites racionais não é uma posição 
cética, não implicando em um argumento cético sobre a limitação do conhecimento, pois, se não, o consenso sobreposto seria inviabilizado. Antes, é obtido por experiência histórica e não por um argumento de dúvida do conhecimento e da razão: "Essa dificuldade resulta da experiência histórica, dada por séculos de conflitos sobre crenças religiosas, filosóficas e morais" (RAWLS, 1996, p. 63). Isso não impede que alguns agentes possam ter uma crença epistemológica de segunda ordem, mas isso não é uma exigência para todo o agente moral. No geral, o agente deve ter um "saber como" ser razoável, não necessitando de um "saber que" a razoabilidade seja uma premissa verdadeira. Nada mais é do que um respeito tolerante aos valores defendidos pelas outras pessoas e isso se aprende mais com a história do que com a epistemologia. Então, seria demasiado exigir do cidadão algum conhecimento da história? Creio que não, da mesma forma que não seria demasiado exigir esse tipo de conhecimento do agente moral em razão dele mesmo ser um cidadão.

Mas, se as pessoas não forem efetivamente razoáveis, não seria ineficaz essa exigência? A isso respondo que o argumento central da justiça como equidade não requer que os agentes sejam de fatos razoáveis, mas que possam ser razoáveis. Dito de outra forma, a teoria moral rawlsiana pressupõe uma importante distinção entre 'competência e performance' e isso implica em dizer que a exigência da razoabilidade recai sobre essa capacidade moral e não sobre a real ação dos agentes ${ }^{18}$. Tudo o que a teoria de Rawls necessita é que os indivíduos possam agir razoavelmente, que possam escolher a partir do que seria uma posição de razoabilidade, mas não precisa contar com a ação real dos sujeitos. Para Rawls:

Agora se pode pensar inicialmente da filosofia moral (e eu ressalto a natureza provisória dessa concepção) como uma tentativa de descrever nossa capacidade moral, ou, no caso presente, se pode pensar uma teoria da justiça como descrevendo nosso senso de justiça. (RAWLS, 1971, p. 46; 1999, p. 41) ${ }^{19}$.

Para provar o argumento, basta mostrar que uma ou algumas pessoas são de fato razoáveis. Dessa forma, se pode perceber que a própria pesquisa de Deana Kuhn que é utilizada por Gaus prova o argumento central da justiça como equidade, uma vez que a investigação mostra que um pouco menos da metade dos sujeitos investigados agem de forma razoável, isto é, 
mostra que os sujeitos não são absolutistas em seus juízos cotidianos. Isso já é o bastante para se estipular que os agentes morais devem agir razoavelmente, uma vez que eles possuem a capacidade para agir dessa forma moral, pressuposto tal que se pode comprovar ao mostrar que pessoas reais de fato agem razoavelmente.

\section{IV}

Nessa parte final do texto, eu quero ressaltar qual o ganho que podemos ter ao usar a razoabilidade ao invés da verdade como critério objetivo para a determinação do que é o justo.Vejamos isso a partir da forma como a justiça como equidade estabelece os preceitos da discussão razoável. Sendo uma pessoa razoável aquela que tem consciência dos limites da razão e do juízo, ela reconhecerá certos preceitos para orientar a deliberação e a discussão no âmbito público. Esses preceitos de razoabilidade são: (i) disposição para alcançar o acordo razoável na discussão política; (ii) estabilidade psicológica para encontrar desacordos substanciais sobre questões básicas (questões constitucionais e de justiça básica); (iii) disposição para creditar aos outros uma certa boa fé, aceitando a diversidade (RAWLS, 1989, p. 478-479). O que isso mostra? Que uma concepção de justiça que está sendo construída a partir do critério da razoabilidade ou aceitabilidade (preferencialmente do que ao critério de verdade), não precisa estar comprometida nem com um realismo ontológico, nem com um fundacionalismo epistemológico e nem mesmo com um representacionalismo semântico. Com o uso de um critério de verdade não mínimo temos um modelo de filosofia moral e política que se baseia na descoberta de determinadas premissas que fundamentarão os princípios morais, sendo essa descoberta dada por um indivíduo a partir de sua razão privada, não havendo a valorização da história para essa deliberação individual em razão do teste final ser dado por correspondência. Isso implicará em dualismo, dogmatismo, assimetria e input solipsista. Alternativamente, com o uso do critério de razoabilidade, conseguimos superar os problemas epistemológicos anteriormente citados. Isso em razão, principalmente, desse modelo coerentista e pragmatista fazer uso de premissas que podem ser publicamente reconhecidas a partir de uma razão coletiva, o que traz por 
consequência a valorização da história nessa deliberação social. Veja-se que o problema do input solipsista é resolvido, uma vez que a determinação das normas morais será dada por um teste da coerência e da eficiência, com o respeito à reciprocidade. Note-se, também, o ganho desse modelo para se pensar a respeito da responsabilidade moral do agente. No modelo de descoberta, a ação moral verdadeiramente responsável poderia pressupor uma escolha verdadeira pelo o que se é (o tipo de pessoa que se é); e como as pessoas não podem escolher verdadeiramente como são, elas não seriam verdadeiramente responsáveis por suas ações ${ }^{20}$. Com o modelo de reconhecimento, como é o modelo coerentista de Rawls, podemos substituir o 'verdadeiramente' pelo 'razoavelmente' e o 'como se é pelo 'o que se pode ser' e, assim, teríamos:

(i) A ação moral razoavelmente responsável pressupõe uma escolha razoavelmente responsável pelo o que se pode ser;

(ii) As pessoas podem escolher razoavelmente como podem ser;

(iii) Logo, as pessoas são razoavelmente responsáveis por suas ações.

O termo 'razoavelmente' significa aqui que se seguiu os preceitos da discussão razoável, o que implica tomar o razoável pelo o que tem aceitabilidade social. Assim, ser responsável por uma ação não é ser responsável nem pelo que se é e nem por todas as suas consequências. Antes, é uma responsabilidade que está centrada na deliberação do agente que pesa razões e escolhe a melhor alternativa. Por isso, o agente pode ser responsabilizado pelo tipo de pessoa que ele pode ser, pois tem capacidade de agir de forma moral (senso de justiça) e racional (concepção de bem) e, assim, sua ação pode ser responsabilizada. Não se trata de uma responsabilidade última, é claro, mas de uma concepção exequível de responsabilidade moral, que está circunscrita a um âmbito de pluralismo moral razoável. E assim, toda a dramatização a respeito da perda da normatividade da justiça como equidade, em razão da ausência do critério de verdade, creio que se mostra excessiva.

${ }^{1} \mathrm{O}$ equilíbrio reflexivo é o método por excelência da justiça como equidade, o que já revela sua filiação a uma epistemologia coerentista do tipo holística, isto por que o que será exigido 
para a justificação de uma crença moral será que ela deve ser coerente não apenas com outra crença, mas com um conjunto coerente de crenças. No artigo "Reply to Habermas", Rawls faz referência ao equilíbrio reflexivo pleno (full) como um ponto ao infinito que nós nunca poderemos alcançar, mas que podemos chegar próximos através da discussão em que nossos (i) ideais, (ii) princípios e (iii) juízos pareçam mais razoáveis para nós, apresentando como característica central a intersubjetividade: "The overall criterion of the reasonable is general and wide reflective equilibrium; (...). Reflective equilibrium resembles his test in this respect: it is a point at infinity we can never reach, though we may get closer to it in the sense that though discussion, our ideals, principles, and judgments seem more reasonable to us and we regard them as better founded than they were before." (RAWLS, 1995, p. 384-385). "Thus citizens have achieved general and wide, or what we may refer to as full, reflective equilibrium. (The adjective 'full' we reserve for features as realized in a well-ordered society)". (RAWLS, 2001, p. 31). O uso do equilíbrio reflexivo geral, ou consenso sobreposto, também parece apontar para uma filiação a uma tradição pragmatista de justificação, que conecta de forma forte a justificação com a questão da legitimação (detalharei esse ponto mais adiante). Creio que podemos afirmar, sem um grande receio de errar o alvo, que o método nada mais é do que um teste de aceitabilidade pessoal/social, teste que é tanto em primeira (equilíbrio reflexivo amplo), quanto em terceira pessoa (equilíbrio reflexivo geral). A sua função é mostrar para nós os valores morais que nós já aceitamos de um ponto de vista social e orientar nossa deliberação moral nessa mesma direção.

2 "We collect such settled convictions as the belief in religious toleration and the rejection of slavery and try to organize the basic ideas and principles implicit in these convictions into a coherent political conception of justice. These convictions are provisional fixed points that it seems any reasonable conception must account for. We start, then, by looking to the public culture itself as the shared fund of implicitly recognized basic ideas and principles". (RAWLS, 1996, p. 8).

${ }^{3}$ Essa referência à exigência de razoabilidade se dá a partir dos cinco fatos gerais que são tomados como pontos de partida da justiça como equidade: (i) pluralismo razoável, (ii) fato da opressão, (iii) apoio ao regime democrático, (iv) ideias intuitivas da cultura pública, (v) revisibilidade das crenças. A esses fatos gerais se adicionam duas ideias normativas de (i) sociedade cooperativa e (ii) pessoas livres e iguais.Ver RAWLS, 1989, p. 474-478 e RAWLS, 1996, p. 48-58.

4 "The first basic aspect of the reasonable, then, is the willingness to propose fair terms of cooperation and to abide by them provided others do. The second basic aspect, as I review now, is the willingness to recognize the burdens of judgment and to accept their consequences for the use of public reason in directing the legitimate exercise of political power in a constitutional regime". (RAWLS, 1996, p. 54). Um esclarecimento para a tradução da expressão "burdens of judgment". O termo "burden" é melhor traduzido como "carga" ou "sobrecarga". O problema é que a expressão "sobrecarga do juízo" diz muito pouco. Dessa forma, usarei preferencialmente "limites do juízo" e "limites da razão" para "burdens of reason", pois creio que melhor expressa a ideia do texto, que é a do reconhecimento de que a razão não é capaz de encontrar uma justificação última para os juízos morais dos cidadãos.

${ }^{5}$ Os procedimentos da posição original e equilíbrio reflexivo são explicados detalhadamente em RAWLS, 1999, \4 e 9. Importante observar que esse procedimento de construção e teste não faz uso de um processo inferencial de conhecimento em que os princípios de justiça

doispontos, Curitiba, São Carlos, vol. 10, n. 1, p.37-59, abril, 2013 
seriam deduzidos de premissas autoevidentes. Alternativamente, a justificação é tomada como uma questão de apoio mútuo de várias considerações, todas elas encaixando em conjunto numa visão coerente. Ver RAWLS, 1999, p. 19. Por outro lado, a função do procedimento do consenso sobreposto é garantir a estabilidade social pelas razões corretas, de forma que pessoas que professam doutrinas abrangentes razoáveis podem endossar uma mesma concepção política de justiça, cada qual a partir de seu próprio ponto de vista.Ver RAWLS, 1996, p. 134.

${ }^{6}$ Sintetizando, o argumento de Raz no artigo "The Case of Epistemic Abstinence" é o seguinte: como a justiça como equidade tem uma tarefa prática de possibilitar estabilidade social e não teórica, tendo um fundamento fraco nos valores morais comuns dados pela tradição, sendo tomada como autossuficiente e, consequentemente, sofrendo de abstinência epistêmica, mesmo se falsa a teoria poderia ser aceita se realizasse seu papel prático. Diz que se evitarmos a abstinência epistêmica nós reconheceríamos que o papel prático dos princípios de justiça em alcançar o consenso sobreposto que garante unidade e estabilidade seria uma questão teórica sobre a verdade dos princípios. Ver RAZ, 1990, p. 16. Isto significa que para Raz, justificação está necessariamente conectada a uma ideia de verdade. Para Estlund, diferentemente, como apontado no final de seu artigo, determinadas obrigações podem estar fundadas na sua legitimidade e não na verdade. Em outras palavras, ele avalia que a força coercitiva do poder político é legítima com base em sua aceitabilidade/razoabilidade, isto é, com base na aceitação dessas regras por parte de pessoas razoáveis e racionais, o que revela que ele está distinguindo justificação de verdade e a aproximando da legitimação. A discordância em relação a Rawls se dá por ele achar que essa proposta falhará a menos que sua doutrina fundamental, o critério de aceitabilidade, seja ao menos aproximadamente verdadeira.Ver ESTLUND, 1998, p. 275.

${ }^{7}$ Veja-se que Estlund e Raz não estão isolados nessa posição crítica que também é compartilhada por vários outros autores, como é o caso de Alan Thomas. Ele faz uma interpretação muito semelhante à de Estlund, reivindicando que o princípio da restrição ao razoável para a justificação/legitimação deve ele próprio ser verdadeiro e não apenas razoável. Em suas próprias palavras: "Precisamos procurar por verdades independentes em uma moralidade política sui generis para melhorar o sentido geral dessa posição" (THOMAS, 2010, p. 282). A esse respeito, ver, também, o artigo de Gardiner: "Rawls on Truth and Toleration" (GARDINER, 1988, p. 103-111).

${ }^{8}$ Esta crítica esta situada em uma proposta mais ampla de defender uma justificação moral contextualista, defendendo um contextualismo estrutural. É nessa perspectiva que ele investigará sobre um ideal realístico de responsabilidade epistêmica. Ver TIMMONS, 2004, p. 178-246.

${ }^{9}$ Este parece ser o argumento central desenvolvido por Marilyn Friedman no artigo "John Rawls and the Political Coercion of Unreasonable People". Ela defende que as pessoas geralmente não são razoáveis em razão de terem crescido sob instituições injustas ao invés de sob instituições livres como as postuladas no ideal de sociedade bem-ordenada de Rawls. Ver FRIEDMAN, 2000, p. 16-19.

${ }^{10}$ Gaus cita a pesquisa de Deanna Kuhn para mostrar a inviabilidade de contar com o reconhecimento dos limites dos juízos para a justificação, uma vez que ela mostra que ao menos metade dos sujeitos investigados (entre a adolescência até a idade madura) se revelaram absolutistas em seus juízos. O estudo coordenado por Kuhn revelou que mais da metade das pessoas

doispontos, Curitiba, São Carlos, vol. 10, n. 1, p.37-59, abril, 2013 
investigadas que deviam explicar as causa do crime, desemprego e falha na escola, viam suas crenças como corretas e nunca como erradas. Esse estudo está documentado em The Skills of Argument.Ver GAUS, 1996, p. 134-135.

11 "Observe that here being reasonable is not an epistemological idea (though it has epistemological elements). Rather, it is part of a political ideal of democratic citizenship that includes the idea of public reason". (RAWLS, 1996, p. 62)

${ }^{12}$ A passagem inteira é a seguinte: "We hope that by doing this we can, in working political practice, firmly ground the constitutional essentials in those political values alone, and that these values will provide a satisfactory shared basis of public justification." (RAWLS, 1989, p. 485).

13 Maffettone fala acertadamente de uma "conexão estrutural entre dois tipos de consenso - entre o liberalismo e a democracia e entre justificação e legitimação" (MAFFETTONE, 2010, p. 249). A tese de Maffettone é que se pode responder a esse tipo de crítica a respeito da pretensa fraqueza do critério de razoabilidade ressaltando que justificação e legitimação estão conectadas na forma que Rawls pensa a justificação das normas, conectando um consenso ideal com um consenso real. Ele explica esta complementaridade entre justificação e legitimação na forma de um ‘institucionalismo normativo’ (MAFFETTONE, 2010, p. 23). Ver a seminal reflexão sobre a centralidade do critério de razoabilidade na justiça como equidade em MAFFETTONE, 2010, p. 237-249. Numa direção similar, Laden ressalta um projeto alternativo da justiça como equidade, destacando quatro importantes elementos. Para nossa discussão específica, chamo atenção para os elementos 3 e 4: (3) seus argumentos são estabelecidos para servir de justificação pública preferencialmente a que sejamtomados como deduções a partir de premissas sobre a natureza humana ou racionalidade e (4) a ideia central e o ponto mais alto de seu projeto é a ideia de razão pública e deliberação pública.Ver LADEN, 2003, p. 379. 14 "The search for reasonable grounds for reaching agreement rooted in our conception of ourselves and in our relation to society replaces the search for moral truth interpreted as fixed by a prior and independent order of objects and relations, whether natural or divine, an order apart and distinct from how we conceive of ourselves". (RAWLS, 1980, p. 306)

${ }^{15}$ Freeman também pensa que é possível aproximar o conceito de razoável com verdadeiro: "Rawls também acredita que a justiça como equidade é a concepção política mais razoável (ou verdadeira, se você quiser) e que ela está em uma melhor posição para encontrar o critério de reciprocidade e possibilitar uma base para a justificação pública requerida pelo princípio liberal de legitimidade".Ver FREEMAN, 2009, p. 230.

${ }^{16}$ Isso pode soar estranho, mas é precisamente isso que Rawls faz. Veja sua definição de justificação: "Preferencialmente, justificação é endereçada aos outros que discordam de nós e, dessa forma, deve sempre proceder de algum consenso, isto é, de premissas que nós e os outros reconhecemos publicamente como verdadeiras; ou melhor, que reconhecemos publicamente como aceitáveis para nós para o propósito de estabelecer um acordo viável sobre questões fundamentais de justiça política." (RAWLS, 1985, p. 394).Veja-se que aqui "premissas verdadeiras" e "premissas aceitáveis" estão sendo tomadas como intercambiáveis. A substituição do termo "verdadeiras" por "aceitáveis" parece ter a função específica de ressaltar que não se fará uso de uma epistemologia representacionalista e uma ontologia realista.

doispontos, Curitiba, São Carlos, vol. 10, n. 1, p.37-59, abril, 2013 
17 "It is unrealistic - or worse, it arouses mutual suspicion and hostility - to suppose that all our differences are rooted solely in ignorance and perversity, or else in the rivalries for power, status, or economic gain". (RAWLS, 1996, p. 58).

${ }^{18}$ Estou fazendo uso de uma interessante abordagem de John Mikhail que interpretou a justiça como equidade como fazendo uso da hipótese de uma gramática moral universal, em que os seres humanos nascem com uma gramática moral, em analogia com a gramática linguística como postulada por Chomsky, analogia feita por Rawls em RAWLS, 1999, \ 9. Não quero me deter na abordagem naturalística feita por Mikhail, da qual eu tenho muitas reservas, mas ressaltar a importância da distinção que ele identifica na justiça como equidade. Mikhail defende que a distinção entre competência e performance, que é tão importante na teoria linguística de Chomsky, também é utilizada por Rawls, distinguindo o que é competência moral e performance moral. Para ele, a competência moral está associada ao conhecimento moral individual, sendo as condições mentais do agente para ação, enquanto que performance moral está associada a como o conhecimento moral é usado, isto é, com o comportamento moral dos indivíduos. Ver MIKHAIL, 2011, p. 17-19.

19 "Now one may think of moral philosophy at first (and I stress the provisional nature of this view) as the attempt to describe our moral capacity; or, in the present case, on may regard a theory of justice as describing our sense of justice". (RAWLS, 1971, p. 46; 1999, p. 41).

20 Estou pensando em uma compreensão de responsabilidade moral como a de Galen Strawson, que conecta em última instância responsabilidade da ação com uma escolha verdadeira sobre o tipo de pessoa. que se é (autodeterminação). Ele prova a impossibilidade da responsabilidade moral com o seguinte argumento básico: (i) A ação moral verdadeiramente responsável pressupõe uma escolha verdadeiramente responsável pelo que se é (o tipo de pessoa que se é); (ii) As pessoas não podem escolher verdadeiramente pelo que são (não podem se autodeterminar); (iii) Logo, as pessoas não são verdadeiramente responsáveis por suas ações. Ver STRAWSON, 1994, p. 6-7.

\section{Referências bibliográficas} 1980. Kantian Constructivism in Moral Theory. In: Collected Papers, p. 303-358.

1985. Justice as Fairness: Political not Metaphysical. In: Collected Papers, p. 388-414.

1989. The Domain of the Political and Overlapping

Consensus. In: Collected Papers, p. 473-496.

1995. Reply to Habermas. In: Political Liberalism, p. 372-434. 1996. Political Liberalism. New York: Columbia University

Press. 
. 1999. A Theory of Justice. Revised Edition. Cambridge, Mass.:

Harvard University Press.

.1999a. Collected Papers. Ed. S. Freeman. Cambridge, Mass.:

Harvard University Press.

2001. Justice as Fairness: A Restatement. Ed. E. Kelly. Cambridge, Mass.: Harvard University Press.

ESTLUND, D. 1998. The Insularity of the Reasonable: Why Political Liberalism Must Admit the Truth. Ethics, v.Vol. 108, n.No. 2, p. 252-275.

FREEMAN, S. 2009. Justice and the Social Contract: Essays on Rawlsian Political Philosophy. New York: Oxford University Press.

FRIEDMAN, M. 2000. John Rawls and the Political Coercion of Unreasonable People. In: DAVION,Victoria; WOLF, Clark. The Idea of a Political Liberalism: Essays on Rawls. Oxford: Rowman \& Littlefield, p. 16-33.

GARDINER, B. 1988. Rawls on Truth and Toleration. The Philosophical Quarterly, vVol. 38, nNo. 150, p. 103-111.

GAUS, G. 1996. Justificatory Liberalism: An Essay on Epistemology and Political Theory. New York: Oxford University Press.

LADEN, A. S. 2003. The House That Jack Built:Thirty Years of Reading Rawls. Ethics, v.Vol. 113, n.No. 2, p. 367-390.

MAFFETTONE, S. 2010. Rawls: An Introduction. Cambridge: Polity Press.

MIKHAIL, J. 2011. Elements of Moral Cognition: Rawls' Linguistic Analogy and the Cognitive Science of Moral and Legal Judgment. New York: Cambridge University Press.

RAWLS, J. 1971. A Theory of Justice. Original Edition. Cambridge, Mass.: Harvard University Press.

RAZ, J. 1990. Facing Diversity: The Case of Epistemic Abstinence. Philosophy and Public Affairs, v.Vol. 19, n.No. 1, p. 3-46. 
STRAWSON, G. 1994. The Impossibility of Moral Responsibility.

Philosophical Studies, v.Vol. 75, No.n. 1/2, p. 5-24.

THOMAS, A. 2010. Value and Context:The Nature of Moral and Political Knowledge. Oxford: Oxford University Press.

TIMMONS, M. 2004. Morality without Foundations: A Defense of Ethical Contextualism. New York: Oxford University Press. 
0 0 


\section{0 debate dos desencontros: uma avaliação das críticas de Michal Sandel ao liberalismo de John Rawls}

Flávio Azevedo Reis

flavio_a_reis@hotmail.com

Universidade do Estado de São Paulo (USP), São Paulo, Brasil

resumo 0 principal objetivo de Micheal Sandel, no livro Liberalismo e os limites da justiça, foi atacar o conceito de deontologia de John Rawls. Nesse artigo, pretende-se argumentar que Sandel interpretou o conceito de deontologia de um modo equivocado. Há uma diferença entre a forma como Rawls definiu este conceito e a maneira como foi interpretado por Sandel. Dado isso, na primeira parte desse artigo, será analisado o modo como Sandel interpretou o conceito de deontologia na filosofia de Rawls. A segunda parte apresenta uma avaliação do confronto entre os dois autores à luz da diferença no modo como ambos compreendem o significado da deontologia no liberalismo político.

palavras chave Liberalismo; Comunitarismo; John Rawls; Michael Sandel; Deontologia; Teoria da Justiça

\section{1) A crítica}

É notório que Rawls, no livro O liberalismo político, negou que as mudanças em sua filosofia pudessem ser atribuídas às críticas dos autores comunitaristas. Ao mencionar Michael Sandel, Rawls insiste que ele não compreendeu adequadamente o seu projeto filosófico. Suas respostas ressaltam erros na interpretação da ideia de "prioridade do correto (right)" e no papel da concepção de pessoa no construtivismo kantiano. Neste artigo, pretendo argumentar que Rawls definiu o conceito de deontologia (e a prioridade do correto) de um modo distinto do interpretado por Sandel. Se esta hipótese estiver correta, talvez seja possível interpretar a ênfase que 
Rawls atribuiu à relação entre o correto e o bem como uma tentativa de desmentir a leitura proposta por Sandel, que define a deontologia como a independência entre o correto e o bem. (v. RAWLS, 1996, pp.173-8; V, $\$ \$$ 1-2). O principal objetivo aqui é entender como as divergências na interpretação do conceito de deontologia poderiam auxiliar nossa compreensão das questões filosóficas que definem o debate entre os dois autores. Com isso, pretendo apontar que o modo como Sandel descreve os objetivos do liberalismo político de Rawls poderia levar os seus leitores a uma compreensão inadequada do projeto filosófico rawlsiano. ${ }^{1}$

No livro Uma teoria da justiça, Rawls definiu o conceito de deontologia a partir da distinção entre três conceitos da ética: correto (right), bem e dignidade moral (moral worth). As concepções teleológicas consideram o conceito do bem como independente do correto, e o conceito do correto como um meio para realização do bem. Para Rawls, uma concepção deontológica nega a teleologia, ou seja, ela nega a independência do bem e/ou o papel instrumental do correto como meio para realização do bem. Um dos principais objetivos do livro Uma teoria da justiça foi propor uma estrutura alternativa dos conceitos éticos que, por oposição à teleologia, deveria atribuir prioridade ao correto em relação ao bem. Isso significa que uma teoria deontológica estava preocupada, em primeiro lugar, com a relação adequada entre os conceitos de correto e bem, não com sua independência ou separação.

Michael Sandel, por outro lado, interpreta a deontologia como a fundamentação do correto independente do bem. Segundo a sua interpretação, Rawls segue uma concepção kantiana de deontologia que identifica as concepções de bem como inclinações empíricas e contingentes. Uma concepção deontológica de justiça não poderia derivar os seus princípios a partir do bem, pois isso iria eliminar a sua capacidade crítica. O correto deve estar afastado das concepções contingentes e empíricas de bem, pois o seu objetivo é servir como critério para avaliar essas contingências. Há uma necessidade, Sandel argumenta, de distinguir claramente o critério de avaliação (correto) dos objetos avaliados (bem). Derivar o correto a partir do bem significaria reproduzir os valores já presentes nas concepções empíricas de bem e, portanto, solapar a capacidade crítica do correto enquanto critério de avaliação. Assim, Rawls teria aprendido com Kant que o poder crítico do correto está 
intimamente ligado ao modo como ele é fundamentado. O correto só poderá julgar adequadamente as concepções de bem, se ele tiver um fundamento independente delas.

A deontologia possui dois significados de acordo com Sandel: (1) o correto, como critério de avaliação, deve ser moralmente independente e anterior aos objetos que ele avalia. Ele representa deveres e proibições categóricas que precedem qualquer consideração prática. Nessa perspectiva, a deontologia se opõe ao consequencialismo; (2) para realizar a prioridade moral, o correto deve ser fundamentado de forma independente dos objetos que ele avalia. Nesse caso, ele deve ser independente de qualquer consideração em relação à boa vida. Nessa segunda perspectiva, a deontologia se opõe à teleologia. (v. SANDEL, 1998, p. 3). A leitura de Sandel pressupõe que Rawls combina ambos os significados da deontologia e, desse modo, assume uma tensão indelével entre contextualismo e universalismo. Por um lado, há a contingência empírica das diversas concepções de bem e dos diversos valores concorrentes que existem nas sociedades contemporâneas. Por outro, há a necessidade moral de apresentar o correto como critério de avaliação daqueles valores e práticas contingentes.

O ponto mais importante da leitura de Sandel é o seguinte: a forma pela qual se fundamenta a concepção de justiça esta ligada a uma concepção de pessoa. Para Sandel, o modo como uma teoria estabelece a relação entre a justiça (correto) e o bem depende da forma como é concebida a relação entre o sujeito e seus fins. Uma concepção de justiça derivada de forma a priori (sem nenhuma relação com os valores empiricamente dados em uma sociedade) depende, segundo Sandel, de uma noção de sujeito capaz de se desvincular totalmente de suas determinações empíricas (sujeito desencarnado). Por outro lado, uma concepção de justiça derivada a partir dos valores morais de uma determinada sociedade pressupõe uma concepção de sujeito como totalmente determinado pela sua situação empírica (sujeito radicalmente situado). Esta é uma tese central para a sua argumentação: a forma pela qual se deriva a concepção de justiça depende do modo como o sujeito é concebido. Uma concepção de justiça desvinculada da situação empírica depende de uma noção de sujeito também desvinculado de sua situação empírica. Uma concepção de justiça derivada das circunstâncias empíricas depende de uma noção de sujeito vinculado a essas mesmas circunstâncias. 
Sandel diz que ambas as alternativas são inaceitáveis para Rawls. Segundo ele, Rawls deve encontrar um "ponto arquimediano" entre elas. Para que a justiça possa servir como critério de avaliação, é necessário distinguir o critério de avaliação da coisa avaliada. Portanto, não é aceitável derivar a concepção de justiça a partir dos dados empíricos, pois isto resultaria apenas na justificação de práticas já existentes. Sem uma distinção clara entre o critério de avaliação e a coisa avaliada, a justiça não poderia servir como "ponto de vista crítico" a partir do qual se poderiam julgar as diversas concepções de bem. Por outro lado, seria igualmente insatisfatório derivar a concepção de justiça a partir de dados puramente abstratos, sem relação alguma com a realidade empírica a qual ela irá se aplicar. Uma derivação a priori seria infundada (groundless) (v. SANDEL, 1998, p. 17). O projeto teórico rawlsiano, segundo Sandel, consiste em formular uma concepção de justiça que, ao mesmo tempo, seria independente das circunstâncias empíricas (de modo que esta concepção de justiça sirva de ponto de vista crítico e garanta a primazia da justiça sobre o bem), mas também mantenha alguma relação com estas circunstâncias de forma que a concepção não se torne infundada e arbitrária. O desafio é encontrar um equilíbrio entre essas duas exigências antagônicas: uma concepção de justiça que, ao mesmo tempo, seja fundamentada independentemente dos valores pré-existentes em uma sociedade, mas que possa ser aplicável a uma sociedade real.

Segundo Sandel, Rawls teria combinado elementos em sua teoria que permitem pesar ambas as exigências. Por um lado, na posição original, as partes escolhem os princípios de justiça sob um "véu de ignorância" que as impede de saber quais são as suas concepções de bem, as suas localizações na sociedade, suas características psicológicas, etc. Isto garante que a decisão não seja diretamente vinculada a interesses empiricamente dados. A concepção de justiça escolhida neste contrato hipotético mantem uma certa independência em relação às condições empíricas. Por outro lado, a construção desta situação contratual (a posição original) leva em consideração as "circunstâncias da justiça”" (v. SANDEL, 1998, p. 29), ou seja, as condições de aplicação da concepção de justiça. Assim, a situação contratual inclui elementos que indicam a sua aplicação à sociedade e homens reais.

O problema do conflito entre fundamentação e aplicação ganha uma nova faceta neste momento. Se Rawls inclui considerações empíricas, sob a forma das "circunstâncias da justiça”, então a sua teoria abarcaria várias 
contradições. Seriam duas exigências aparentemente incompatíveis: por um lado, uma concepção afastada das contingências empíricas garante a primazia da justiça, mas pode se distanciar da condição real das sociedades humanas; por outro lado, uma concepção comprometida com o empírico pode garantir uma ligação com as circunstâncias reais, mas poderia excluir a primazia da justiça.

É esta combinação incerta que levanta as objeções que nós

consideramos, enquanto a concepção kantiana de lei moral e do reino dos fins parece negar à justiça a sua situação humana, a consideração humeana [David Hume] da situação humana parece ser incapaz de acomodar reivindicações fortes a favor da primazia da justiça. Porém, entender como estas inconsistências surgem não as dissolvem, mas apenas confirmam. Também poderia parecer que as duas aspirações da teoria de Rawls, evitar tanto as contingências dos desejos existentes e a suposta arbitrariedade e obscuridade do transcendente, são incombináveis. O ponto arquimediano seria eliminado em uma ladainha de contradições. (SANDEL, 1998, p. 40)

A solução de Rawls para estas contradições, segundo Sandel, é o método do equilíbrio reflexivo. A justificação da concepção de justiça pressupõe que nós possuímos crenças e valores morais, que se expressam na forma de juízos ponderados. Os pressupostos da teoria não estão sustentados em uma avaliação diretamente empírica da sociedade, mas sim em sua validade diante dos nossos juízos após a devida reflexão. Isso significa que os juízos ponderados podem incluir considerações empíricas acerca das circunstâncias para aplicação da justiça sem pressupor um teste diretamente empírico. A validade dessas considerações é dada pelos juízos em equilíbrio reflexivo, que não dependem diretamente de dados empíricos fornecidos pela sociologia ou psicologia. Sandel argumenta que a inclusão de pressupostos empíricos não solapa a força deontológica da teoria porque eles não são plenamente empíricos. Esses pressupostos são apenas as nossas crenças e valores acerca das circunstâncias sociais. A justiça pode, desse modo, fazer uma referência às condições de sua aplicação sem destruir a independência do correto.

Para Sandel, o método do equilíbrio reflexivo resolveu a tensão entre as exigências universalista e contextualista na filosofia de Rawls. Ele não 
acredita que Rawls buscou uma fundamentação de princípios de justiça completamente descolada da realidade, e o principal alvo de sua crítica não é uma suposta pretensão universalista na filosofia de Rawls. Pelo contrário, a interpretação de Sandel apresenta a filosofia de Rawls como a combinação do melhor dos dois mundos, ou seja, a força moral da filosofia kantiana e o realismo da empiria de David Hume. Assim, Sandel considera que Rawls forneceu uma solução satisfatória para essa questão. A sua crítica ao liberalismo se volta contra outro ponto: a divisão entre o correto e o bem. Ele acredita que o liberalismo pretende separar o correto do bem, mas é incapaz de fazê-lo.

Para Sandel, a forma como se constrói uma concepção de justiça está intimamente ligada a uma concepção de pessoa. Se Rawls deseja encontrar um "ponto arquimediano" entre duas formas inaceitáveis de fundamentar a justiça (totalmente empírica ou totalmente a priori), então ele também necessita de uma concepção de sujeito que seja um "ponto arquimediano" entre o sujeito desencarnado (totalmente descolado das condições empíricas) e um sujeito radicalmente situado (totalmente inserido nas circunstâncias empíricas). Segundo Sandel, Rawls não expôs a sua concepção de sujeito. Assim, ele pretende investigar as entrelinhas da filosofia rawlsiana em busca da concepção de pessoa implícita ali. $\mathrm{O}$ equilíbrio reflexivo serve como ponte para encontrar essa concepção de pessoa. Dado que a justiça como equidade deve refletir os nossos juízos morais ponderados, a concepção rawlsiana de pessoa estará entre esses juízos.

Antes de prosseguir, devemos deixar claro o modo como Sandel entende o estatuto da concepção de pessoa. Os pressupostos da teoria não são avaliados diretamente em relação às condições empíricas, mas são mediados pelo que Rawls chama de "convicções ponderadas". Desta forma, a validade destes pressupostos não é estritamente empírica, mas diz respeito a estas crenças acerca da justiça. Esta mediação permite que a exigência de aplicação não se torne tão destrutiva à exigência de fundamentação. Assim, a concepção de pessoa que Sandel pretende encontrar na teoria de Rawls não diz respeito à natureza real do ser humano, nem pretende ser validada pela psicologia ou sociologia. A concepção de pessoa reflete nossas crenças e conviç̧ões, que devem ser plausíveis, ou seja, devem ter alguma relação com a realidade, porém não uma relação direta. 
Podemos colocar o nosso problema desta forma: como o equilíbrio reflexivo deixa claro, as condições da posição original não podem ser tão imunes às circunstâncias humanas reais de forma que qualquer pressuposto que produza princípios de justiça seja aceito. A não ser que as premissas tenham alguma semelhança com a condição de criaturas dicernivelmente humanas, o sucesso do equilíbrio é, desta maneira, debilitado. (SANDEL, 1998, p.43)

Segundo Sandel, a concepção de pessoa está mais próxima de uma "antropologia filosófica” do que de uma ciência empírica. (SANDEL, 1998, p. 50)

Devemos notar que o uso da expressão "antropologia filosófica” revela um ponto importante: Sandel considera a concepção de pessoa como uma espécie de "natureza humana". Ela regula todos os aspectos da vida de um indivíduo. Assim, a concepção de pessoa pressuposta nos juízos ponderados terá consequências não apenas para a concepção política de justiça, mas também para as concepções de bem de um indivíduo. A forma como ele compreende a sua relação com o mundo será completamente influenciada pela concepção de pessoa presente em seus juízos ponderados. Ao formular uma concepção de natureza humana para fundamentar os princípios de justiça, Rawls também formula uma concepção que determina o modo como os indivíduos concebem a boa vida. Veremos abaixo que esse pressuposto implícito na crítica de Sandel é um ponto importante para avaliação de sua crítica.

A concepção de pessoa que Sandel identifica na teoria de Rawls, além de ser somente uma concepção "plausível” sustentada por nossas convicções ponderadas, também reflete o "ponto arquimediano". Assim como a justiça, a pessoa não pode estar totalmente descolada das circunstâncias empíricas, e também não pode estar totalmente vinculada a elas. A concepção de pessoa não pode ser a de um self [eu] totalmente independente de sua situação (sujeito desencarnado), nem um self totalmente determinado por ela (sujeito radicalmente situado). Uma questão central para a construção de uma teoria da justiça é a forma como ela define a relação entre o sujeito e os seus fins, isto é, a relação entre o self e as concepções de bem. Podemos formular uma concepção de justiça independente do bem, se o sujeito for distinto dos fins que ele persegue. Assim, poderíamos 
derivar a concepção de justiça a partir deste sujeito e não fazer referência às concepções de bem que ele segue. Se não distinguirmos o self de seus fins, só poderíamos derivar concepções de justiça ligadas às concepções de bem e, desse modo, não seria possível que a justiça e o correto tenham prioridade sobre o bem. As mesmas exigências contraditórias que vimos na construção da teoria da justiça surgem aqui na formulação da concepção de pessoa. Neste caso, é preciso encontrar uma concepção de sujeito que seja o meio termo entre estas duas concepções inaceitáveis. O ponto arquimediano é, segundo Sandel, o "sujeito de possessão": o self que escolhe os seus fins. Desta forma, o self é distinto de seus fins, pois ele é o agente de escolha. Por outro lado, ele está ligado aos fins, porque eles são os objetos da escolha do self. ${ }^{2}$

$\mathrm{Na}$ visão de Rawls, qualquer descrição do self e seus fins deve nos dizer duas coisas: como o selfé distinto de seus fins, e como o selfé conectado com seus fins. Sem a primeira, nós teríamos um sujeito radicalmente situado; sem a segunda, um sujeito radicalmente desencarnado. A solução de Rawls, implícita no desenho da posição original, é conceber o self como um sujeito de possessão, pois, enquanto possuidor, o self esta distante dos seus fins sem estar desconectado deles. (SANDEL, 1998, p. 54)

Isto significa que Rawls se baseia em uma concepção de pessoa na qual o sujeito escolhe os seus fins. Ele está distante das concepções de bem porque seu self é anterior aos seus fins, porém ele se conecta aos seus fins por um ato de vontade.

Para Sandel, essa concepção de pessoa contradiz o conceito de deontologia. Ele supõe que uma concepção deontológica não deveria estar vinculada a uma concepção de bem. Assim, ao identificar o "sujeito de possessão", Sandel argumenta que Rawls incluiu uma definição do bem em sua filosofia. Para mostrar isto, Sandel expõe dois tipos de ação (agency) humana: 1) dimensão voluntarista de ação: o sujeito está separado de seus fins e se conecta com eles por meio de uma escolha, ele se conecta aos seus fins como um sujeito que escolhe (willing subject). "A ação relevante envolve um exercício da vontade, pois é a vontade que é capaz de transcender o espaço entre o sujeito e seu objeto sem fechá-lo" (SANDEL, 1998, p. 58). Temos, então, uma definição do bem como "algo que é escolhido". Mesmo que não possamos determinar o que é este "algo", ainda 
temos uma definição do que é o bem;2) dimensão cognitiva de ação: o fim é um dado anterior ao sujeito. Não se obtém o fim por meio de uma escolha, mas por autoconhecimento:

Quando os fins do self são dados anteriormente, a ação relevante não é voluntária, mas sim cognitiva. Pois o sujeito não conquista autocomando pela escolha do que já está dado, mas pela reflexão em si mesma e pela investigação de sua natureza constitutiva, discernindo suas leis e imperativos, e reconhecendo seus propósitos por si mesmos. (SANDEL, 1998, p. 58)

Conceber a pessoa como um "sujeito de possessão" significa considerar apenas a "dimensão voluntarista da ação". Isto implica que concepções de bem ligadas a uma "dimensão cognitiva da ação" não poderiam ser aceitas. A opção pelo "sujeito de possessão" implica na aceitação de um conjunto determinado de concepções de bem ligado a uma dimensão voluntarista da ação e, desse modo, a exclusão de concepções de bem ligadas ao autoconhecimento. Dizer que é da "natureza humana" escolher os seus fins significa dizer que o bem não pode ser descoberto por autorreflexão.

Além disso, a concepção de sujeito de possessão também exerce influência sobre a relação dos indivíduos com a sociedade. Dizer que o self é anterior aos seus fins significa dizer que a identidade do sujeito está distante de suas determinações empíricas. Isso implica que a concepção de pessoa rawlsiana é individualista. Como o self está distante de qualquer determinação empírica, a identidade do sujeito não pode se definir a partir da comunidade em que ele está inserido. Ao aceitar a concepção de sujeito de possessão, estamos impedidos de conceber relações sociais no sentido constitutivo, ou seja, comunidades que moldam a identidade de seus membros:

Isto exclui a possibilidade de uma vida pública que, por bem ou por mal, coloca em jogo a identidade e os interesses dos seus participantes. Isto exclui a possibilidade de que propósitos e fins comuns possam inspirar um auto-entendimento mais ou menos expansivo e, então, definir a comunidade em um sentido constitutivo, uma comunidade que envolve o sujeito e não somente os objetos de suas aspirações compartilhadas. De uma forma mais geral, Rawls exclui a possibilidade do que podemos chamar de formas "intersubjetivas" ou "intrasubjetivas" 
de auto-entendimento, formas de conceber o sujeito que não partem da pressuposição de suas fronteiras. (SANDEL, 1998, p. 62)

A concepção de sujeito (e de sociedade) presente no pensamento de Rawls, segundo Sandel, exclui concepções de bem comunitárias no sentido constitutivo. Ela pressupõe uma individualidade anterior à sociedade, o que impede a constituição de uma identidade ligada à comunidade.

Ao apontar que há um "sujeito de possessão" na filosofia de Rawls, Sandel argumenta que há uma contradição conceitual no liberalismo. Uma teoria deontológica não deveria supor uma concepção de bem, mas a solução encontrada pressupõe uma concepção de pessoa que define o bem como "algo que é escolhido". Se nós aceitarmos a concepção rawlsiana de justiça como aquela que condiz com os nossos juízos ponderados, devemos implicitamente aceitar que o "sujeito de possessão" determina o modo como definimos o bem e nossa relação com a sociedade. Assim, quando Sandel aponta o contraste entre a dimensão voluntarista da ação e dimensão cognitiva, ele mostra que o liberalismo carrega consigo um modo específico de definir o bem. O contraste entre o sujeito de possessão e a comunidade em sentido "constitutivo" também aponta que o liberalismo inclui uma definição da relação entre a comunidade e os seus membros. Há uma contradição conceitual porque, apesar da intenção de separar a justiça (e o correto) de considerações relativas à boa vida, Rawls inconscientemente reestabelece uma relação entre correto e bem por via do sujeito de possessão. Para Sandel, o liberalismo pretende ser "neutro" em relação ao bem, mas não consegue.

\section{2) A avaliação}

Há duas dificuldades na avaliação da crítica de Michael Sandel, que tornam o seu diálogo com Rawls permeado por desencontros e mal entendidos. Em primeiro lugar, o livro de Sandel foi publicado num momento em que Rawls estava reorientando os objetivos de sua filosofia. As críticas podem ser avaliadas de modos distintos quando comparadas com o livro Uma teoria da justiça, por um lado, ou em relação aos textos que Rawls produziu durante as décadas de 80 e 90 , por outro. A segunda dificuldade 
é o desencontro no modo como ambos os autores definem o conceito de deontologia. Rawls não interpreta Kant do mesmo modo que Sandel, e também não define a deontologia nos mesmos termos. Por consequência, devo argumentar que, quando comparada com o livro Uma teoria da justiça, a crítica de Sandel está baseada em uma interpretação imprecisa do modo como Rawls definiu a deontologia. Quando comparadas com a "orientação" da filosofia rawlsiana durante a década de 80 , as críticas de Sandel podem ser refutadas a partir da distinção entre concepção política e as concepções abrangentes de bem. A avaliação das críticas de Sandel deve estar atenta à reorientação ocorrida na filosofia de Rawls no início da década de 80 .

Para tornar a argumentação mais clara, podemos começar com um esquema que, apesar de excluir diversas nuances conceituais, nos ajuda a definir os principais pontos do debate. Ressalto que esse esquema contém algumas simplificações que poderiam se tornar imprecisões de leitura, mas ele é válido por promover uma compreensão introdutória dos argumentos expostos a seguir. Podemos supor que uma teoria de justiça seria coerente (i.e. não há contradição conceitual) em duas situações. Cenário I: (a) a teoria pretende formular uma relação entre correto e bem, e (b) estabelece esta relação. Cenário II: (c) A teoria pretende separar correto e bem, e (d) realmente distingue os dois conceitos. Há uma contradição (cenário III) quando a teoria combina (c) e (b), ou seja, ela pretende separar os conceitos, mas estabelece uma relação. De um modo simplificado, seria possível identificar a primeira orientação de Rawls com o cenário I, ou seja, ele pretendia formular uma relação entre os conceitos, e assim o fez. A segunda orientação pode ser identificada, grosso modo, com o segundo cenário: Rawls afasta sua concepção política de justiça das concepções abrangentes de bem. A crítica de Sandel se move na contramão de Rawls porque ela supõe o cenário III, i.e., uma combinação entre (c) e (b). Comparada com a primeira orientação, a premissa (c) está equivocada: Rawls não definiu deontologia como a independência do correto em relação ao bem. Comparada com a segunda orientação, a premissa (b) é refutada, pois Rawls separa sua concepção de justiça das concepções abrangentes de bem. Em ambos os casos, Sandel erra o alvo. Este esquema, repito, não é uma representação precisa dos termos do debate, ele é apenas uma introdução aos argumentos que seguem. Uma das razões que tornam 
este esquema impreciso é a insistência de Rawls, mesmo em seus textos tardios, na afirmação de que a prioridade do correto não exclui uma relação entre correto e bem. O seu esforço, durante a segunda orientação, foi distinguir sua concepção política de justiça de concepções abrangentes de bem, o que não pró́be relação entre a justiça e algumas concepções não-abrangentes de bem (v. RAWLS, 1996, pp. 173-4,V). Voltemos à análise de texto.

No livro Uma teoria da justiça, Rawls não definiu a deontologia como a independência do correto em relação ao bem. Pelo contrário, o seu objetivo foi formular uma teoria moral que deveria estabelecer uma relação adequada entre esses dois conceitos. As concepções teleológicas, segundo Rawls, definem o bem como independente do correto, e o correto como meio para maximizar o bem. Inspirado pela ideia kantiana de autonomia, Rawls pretendeu formular uma teoria alternativa à estrutura teleológica que ele identificou nas concepções utilitaristas. Isso significava negar a independência do bem, e atribuir prioridade ao correto. Dado que Rawls identificou a independência do bem como um dos principais problemas das concepções teleológicas, a sua teoria deontológica assumiu como questão central a relação adequada entre o correto e bem. Isso significa que o projeto filosófico de Rawls durante esse período incluiu uma concepção denominada "bem como racionalidade", que deveria estar relacionada com a concepção de "justiça como equidade". A ideia rawlsiana de deontologia não pretendia excluir a formulação de uma concepção de bem, pelo contrário, ela demandava uma relação adequada entre os dois principais conceitos éticos. (v. RAWLS, pp. 24-30, \$6; REIS, pp. 38-39; FREEMAN, 2007, pp. 45-74)

$\mathrm{Na}$ terceira parte do livro Uma teoria da justiça, Rawls formulou o esboço de uma teoria do bem que poderia determinar princípios capazes de avaliar a racionalidade dos planos de vida. Assim como a teoria da justiça formula princípios para orientar o modo como a estrutura básica de uma sociedade é avaliada, a teoria do bem formula princípios para orientar o modo como as pessoas julgam os seus planos de vida e as escolhas que conduzem à realização desses planos. A concepção de "bem como racionalidade" considera como as pessoas fariam escolhas relativas aos seus planos de vida, supondo a aplicação de princípios de escolha racional e o "princípio aristotélico". A teoria do bem não afirma que 
as pessoas sempre agem racionalmente, nem que elas escolhem seus fins como algo similar ao "livre arbítrio". O bem como racionalidade apenas supõe como elas teriam feito as escolhas importantes em suas vidas, caso houvessem aplicado corretamente os princípios de escolha racional. Desse modo, Rawls formulou princípios que poderiam orientar os nossos juízos acerca do bem. Isso significa que, ao contrário da interpretação de Sandel, Rawls não identifica sua concepção de bem com as "contingências empíricas". Pelo contrário, a teoria do bem formula princípios normativos para a avaliação da boa vida. Por outro lado, a concepção de bem como racionalidade julga o valor dos planos de vida de um modo similar - mas não idêntico - à "dimensão voluntarista da ação", pois inclui uma noção de "escolha" na avaliação da boa vida. Para julgar se um plano de vida é bom ou ruim, a concepção de bem como racionalidade supõe como um indivíduo teria escolhido seu plano, caso ele houvesse aplicado corretamente os princípios de escolha racional e o princípio aristotélico. (v. RAWLS, 1999a, pp. 347-396, \$\$60-68)

Dado que projeto da teoria moral rawlsiana incluiu o desenvolvimento de uma concepção de bem, o livro Uma teoria da justiça não contém a contradição interna que Sandel acredita ter encontrado. No contexto desse livro, Rawls poderia facilmente admitir que a sua teoria moral inclui uma concepção de bem, pois uma parte importante do seu projeto consistia justamente na investigação da relação entre as duas concepções éticas. Sandel acredita ter encontrado uma contradição porque, para ele, uma teoria deontológica pretende ser independente de qualquer noção de boa vida. Ao notar que Rawls esboçou considerações acerca do bem, Sandel argumenta que há uma contradição entre, por um lado, a suposta pretensão de formular uma concepção deontológica de justiça independente do bem e, por outro, a afirmação implícita (e inconsciente) de uma concepção "voluntarista" de bem. Porém, a deontologia do livro Uma teoria da justiça visava uma relação adequada entre as concepções éticas, ou seja, uma teoria deontológica deveria formular uma concepção de bem e investigar a relação entre ela e a justiça (problema da congruência). O "sujeito de possessão" que Sandel afirma estar "implícito" na filosofia de Rawls é uma interpretação imprecisa da concepção de "bem como racionalidade", esboçada na terceira parte do livro Uma teoria da justiça. Ali, Rawls formulou conscientemente as linhas gerais de uma concepção de bem 
que faria parte de sua teoria moral deontológica. Não há, portanto, a suposta contradição conceitual que Sandel pensa ter encontrado na filosofia de Rawls desse período, pois sua teoria deontológica pretendia incluir uma concepção de bem.

Apesar de ser uma leitura imprecisa, Sandel estava correto ao afirmar que Uma teoria da justiça incluía uma concepção abrangente de bem. O objetivo de Sandel, enquanto um autor comunitarista, era defender que a justiça não deveria ser independente do bem. Seria um erro supor que Sandel advoga em favor de uma concepção "constitutiva" de bem e sociedade. Pelo contrário, ele formula as "dimensões da ação" para lançar luz sobre a noção de bem identificada no liberalismo de Rawls. Seu objetivo era criticar o conceito de deontologia e mostrar que a suposta separação entre correto e bem seria uma ilusão. Porém, Sandel estava equivocado ao supor que Rawls pretendeu formular o correto (e a justiça) independente do bem. Sua teoria original deveria incluir uma concepção de "bem como racionalidade". Ironicamente, Sandel atacou Rawls por ele ter feito aquilo que Sandel queria! Rawls incluiu uma concepção de bem em sua teoria moral e foi criticado por isso. A ironia se torna ainda maior quando se observa que, durante a década de 80 , Rawls reorientou sua filosofia na direção contrária da pretendida por Sandel e, com isso, também tornou a sua concepção liberal imune às críticas comunitaristas.

Durante a segunda fase do pensamento de Rawls, ele passou a afirmar que o fato do pluralismo impede a justificação da concepção de bem como racionalidade. Para Sandel, ao assumir a "dimensão voluntarista da ação", Rawls teria reproduzido uma concepção moderna de sujeito e, com isso, rejeitado as concepções de bem, self e comunidade do mundo antigo. Assim, Sandel sugere que a filosofia de Rawls expressa uma visão de mundo exclusivamente moderna. Rawls, por outro lado, identificou um problema diferente. Para ele, ao formular uma concepção de bem na terceira parte de Uma teoria da justiça, a sua teoria moral desconsiderou que as circunstâncias do mundo moderno incluem o fato do pluralismo. Para Rawls, a modernidade é marcada por uma grande diversidade de concepções abrangentes de bem. As pessoas seguem não apenas as concepções que Sandel define como "voluntaristas" e "constitutivas", mas também diversas outras. Durante a década de 80, Rawls passou a afirmar que, ao definir o bem de uma pessoa como "plano de vida racional 
que ela escolhe com racionalidade deliberativa" (RAWLS, 1999a, p. 372, \$65), o livro Uma teoria da justiça estava equivocado por não considerar a diversidade de concepções de bem presentes no mundo moderno. Desse modo, enquanto Sandel argumentava que Rawls formulou uma concepção excessivamente moderna de bem, o próprio Rawls passou a considerar que aquele livro não refletia adequadamente o pluralismo de concepções de bem encontradas no mundo atual, ou seja, o livro não era "moderno" o suficiente.

A resposta de Rawls foi desvincular a justiça como equidade da concepção de "bem como racionalidade" e, desse modo, "transformar a doutrina da justiça como equidade proposta em Teoria em uma concepção política" (RAWLS, 1996, p. Xli, "Introduction to the paperback edition", \3). Entre outras reformulações importantes, Rawls fez uma distinção entre "concepção de pessoa" e "natureza humana". Em Uma teoria da justiça, dado que o projeto de Rawls era formular uma teoria moral que poderia definir o correto $e$ o bem, a concepção de pessoa é identificada com a natureza humana e determina tanto a justiça quanto o bem. (v. RAWLS, 1999a, pp. 491-496, \$85; Idem, pp. 222, \$40; REIS, pp. 87-100). Sandel utiliza essa identificação para argumentar que Rawls pressupõe uma "antropologia filosófica" (sujeito de possessão) que serve como fundamento para a justiça e o bem. Assim, a concepção de natureza humana vincula a justiça liberal a uma definição da boa vida.

No artigo do construtivismo kantiano, Rawls desfez esse vínculo. A concepção de pessoa formulada ali diz respeito somente à identidade pública do cidadão. Ela está mais próxima de uma teoria da cidadania. Aquilo que Sandel identificava como uma concepção de sujeito anterior a seus fins, após esse artigo, passa a significar apenas que a identidade do cidadão não é afetada por mudanças em suas concepções de bem. Para Rawls, a liberdade significa (entre outras coisas) que um cidadão pode mudar seu plano de vida sem perder a sua cidadania ${ }^{3}$. Assim, a concepção de pessoa de Rawls não pressupõe que os seres humanos realmente possuem uma identidade anterior aos seus fins ou distinta do contexto social. Também não pressupõe que eles se veem como sujeitos de possessão. Rawls apenas diz que, no contexto público, a identidade de uma pessoa enquanto cidadã é distinta e anterior às suas concepções de bem, o que permite que ela tenha o direito de modificar suas concepções de bem sem perder o status de cidadã: 
Cidadãos, enquanto pessoas livres, têm o direito de ver as suas pessoas como independentes e não identificadas com um sistema específico de fins. Dado o poder moral de formar, revisar, e perseguir racionalmente uma concepção de bem, suas identidades públicas enquanto pessoas morais e fontes de reivindicações não são afetadas por mudanças ao longo do tempo em suas concepções de bem. (RAWLS, 1999c, p. 331)

Como a concepção de pessoa passou a definir apenas a identidade pública do cidadão, ela não determina sua identidade não-pública. O modo como um cidadão, fora do contexto público, relaciona sua identidade e seus fins não precisa tomar a forma do sujeito de possessão, nem ser avaliada segundo os princípios do "bem como racionalidade":

Os cidadãos em seus assuntos pessoais, ou dentro da vida interna de associações, podem considerar os seus fins e aspirações de forma diferente. Eles podem possuir relações e amores que eles acreditam que não poderiam se afastar; eles podem considerar impensável se ver sem algumas convicções religiosas ou filosóficas específicas. Porém, nada disso afeta a concepção de pessoa conectada com uma concepção pública de justiça e seu ideal de cooperação social. Dentro de diferentes contextos, nós podemos assumir diversos pontos de vista sobre nossa pessoa sem contradições, desde que esses pontos de vistasejam coerentes quando as circunstâncias requerem. Como sempre, nosso foco aqui é a concepção pública que está na base dos princípios de justiça social. (RAWLS, 1999c, pp. 331-2)

Ao fazer a distinção entre a identidade pública de pessoa e a não-pública, Rawls afasta sua concepção de justiça da concepção abrangente de bem como racionalidade e, portanto, desvincula sua filosofia de uma noção "voluntarista" do bem. Com essa distinção, não há mais a suposta contradição entre (c) uma concepção deontológica definida equivocadamente como independente do bem e (b) a definição do bem como "algo escolhido" pelo sujeito de possessão. Durante a primeira fase do pensamento de Rawls, (a) ele pretendeu estabelecer uma relação entre as concepções, e (b) esboçou essa relação na terceira parte do livro Uma teoria da justiça. Após a reorientação de sua filosofia, Rawls desvinculou a justiça como equidade da concepção de bem que possibilitava a interpretação de 
Sandel, ou seja, ele negou (b). Ao aceitar a concepção de justiça rawlsiana, não é mais necessário assumir uma concepção "voluntarista" do bem. $\mathrm{O}$ esforço para adaptar a justiça como equidade aos limites de uma concepção política, por oposição à concepção abrangente do livro Uma teoria da justiça, definiu uma grande parte das publicações de Rawls ao longo da década de 80 e início da década de 90. Assim, apesar de Sandel argumentar contra a separação entre correto e bem (a), a filosofia de Rawls se tornou imune às suas críticas quando se transformou no tipo de concepção liberal que Sandel pretendia combater. Com essa mudança, os pressupostos da justiça como equidade assumem apenas que um cidadão pode mudar sua concepção de bem sem perder a cidadania. A concepção política de pessoa não está mais vinculada com uma concepção abrangente do bem, e muito menos a uma identidade humana enquanto um self que escolhe os seus fins. Ela define somente as características que os cidadãos de uma democracia deveriam reconhecer nos membros de sua sociedade. Quando as críticas de Sandel são comparadas com a segunda orientação da filosofia de Rawls, o autor comunitarista aparece como alguém que confundiu o contexto público da justiça e o contexto não-público das concepções de bem. Ao distinguir os contextos, suas críticas são dissipadas. (v. FORST, 2010. pp. 15-43) ${ }^{4}$

Para Sandel, além da independência da justiça em relação ao bem, a deontologia também é definida por oposição ao consequencialismo. Em relação a este último ponto, Rawls não poderia ter sido mais claro ao afirmar que fazer essa oposição seria "loucura" (crazy) (RAWLS, 1999a, p. 26, \$6). Há uma diferença sutil, porém importantíssima, entre fundamentar princípios independentes das circunstâncias empíricas e utilizar abstrações para orientar o juízo. No primeiro caso, sugerido por Sandel, qualquer vínculo entre os princípios e a empiria prejudica a "deontologia” da concepção de justiça. Para Rawls, o contratualismo (incluindo a posição original) é um procedimento que orienta nossos juízos acerca da estrutura básica da sociedade, ao discriminar as informações relevantes para o nosso julgamento. $\mathrm{O}$ véu de ignorância indica quais informações deveriam ser "excluídas" de nossas considerações de um dado problema, enquanto os princípios de justiça atribuem pesos diversos às informações disponíveis. Dado o ordenamento lexical, informações relativas ao primeiro princípio de justiça tem prioridade em relação ao segundo. Isso significa que o 
contratualismo de Rawls pretende orientar o modo como nós, com base em nossos juízos ponderados em equilíbrio reflexivo, julgamos o ordenamento social a partir de informações empíricas. O contratualismo pretende fornecer critérios abstratos para guiar nossos juízos. Este "nós" também não é um sujeito ahistórico. Pelo contrário, ele representa os cidadãos de sociedades democráticas cujos valores são parcialmente formados pelas instituições que compõem a estrutura básica de sua sociedade. Sandel confunde o uso de ideias abstratas com uma tentativa de fundamentar princípios que negam as contingências históricas e sociais. Este distinção deve ser observada com a devida atenção porque, dado que a interpretação de Sandel é elogiosa, até mesmo um leitor simpático a Rawls poderia aceitá-la, apesar de Rawls haver negado explicitamente a oposição entre deontologia e consequencialismo. Ao aceitar a leitura de Sandel, poderíamos ser levados a assumir que a real tarefa de uma filosofia liberal (e deontológica) seria radicalizar o aspecto "apriorístico" da justiça e, desse modo, correríamos o risco de reduzi-la a formalismos vazios. Ainda pior, poderíamos ser levados a julgar políticas públicas sem considerar as suas consequências práticas 5 .

As respostas de Rawls, em O liberalismo político, parecem desconsiderar qualquer contribuição de Sandel para as correções em sua filosofia. Suas afirmações sugerem que, de seu ponto de vista, as interpretações que sustentam as críticas estavam equivocadas e a resposta deveria ser resumida a esclarecimentos contra os erros interpretativos. Este esforço pode ser observado nos momentos em que Rawls menciona a distinção entre pessoa e natureza humana (RAWLS, 1996. pp. 26-28, I, \$4.5) e na ênfase colocada sobre a relação entre correto e bem. Apesar de distinguir entre a concepção política de justiça e as concepções abrangentes de bem, Rawls insiste que mesmo uma concepção política está ligada a noções de bem. (Idem, pp. 173-4,V). Talvez essa reação possa ser explicada pelo desencontro entre as intenções de Rawls e a interpretação de Sandel. A poderosa leitura do autor comunitarista poderia levar até mesmo admiradores do pensamento rawlsiano a interpretar a tarefa do liberalismo como uma tentativa de equilibrar universalismo e contextualismo, ou como a fundamentação do correto independente do bem. Michael Sandel levanta questões importantes para a filosofia política contemporânea, e suas ideias devem fazer parte do debate atual. Porém, ao buscar uma melhor 
compreensão das questões que permeiam o liberalismo de Rawls, devemos estar atentos para o modo como ele definiu os problemas que a filosofia política deve enfrentar em nossos dias.

${ }^{1}$ A argumentação no presente artigo sustenta a si mesma. Porém, ela pode ser lida como a exploração de algumas consequências da interpretação proposta em REIS, 2012. Dado isso, irei me escusar da reprodução detalhada de argumentos desenvolvidos alhures. O presente artigo pressupõe que há uma diferença importante entre dois períodos da filosofia de Rawls: o livro Uma teoria da justiça foi orientado por objetivos diversos dos trabalhos desenvolvidos por Rawls ao longo das décadas de 80 e 90. Portanto, a reorientação na filosofia de Rawls será considerada como um pressuposto que não precisa ser justificado. Apesar disso, os principais argumentos apresentados aqui podem ser avaliados sem uma referência direta ao texto mencionado. Dado que a reorientação pode ser identificada nas Dewey Lectures (v. RAWLS, 1999c), apresentada dois anos antes da publicação do livro de Sandel, e os problemas que levaram a essa reorientação podem ser encontrados em textos publicados até sete anos antes do livro de Sandel (v. RAWLS, 1999b), seria temerário afirmar que as mudanças na filosofia de Rawls podem ser atribuídas às críticas de Sandel. Porém, a principal preocupação deste artigo não é "historiográfica", mas conceitual. O objetivo é apontar as divergências na interpretação do conceito de deontologia. Para uma análise mais detalhada do conceito rawlsiano de deontologia, (v. REIS, 2012. pp. 10-15; 28-39; 53-9; 80-88). Sobre as razões que levaram Rawls a reorientar sua filosofia. (v. idem pp. 68-73). Sobre a relação entre a justiça e as circunstâncias empíricas, (v. Idem, pp. 20-8). Sobre a segunda orientação da filosofia de Rawls, (v. Idem, pp. 103-142). Para evitar longos argumentos que, dados os atuais propósitos, seriam desnecessários, não será examinada a distinção entre teoria fraca e teoria plena do bem. Para uma análise desses conceitos (v. REIS, 2012, pp. 40-68; RAWLS, 1999a pp. 347-350, \$60; 392-396, \$68). As referências ao livro Uma teoria da justiça serão acompanhadas do número da seção (ex: "\$40" se refere à seção denominada "Kantian Interpretation of Justice as Fairness"). O livro O liberalismo político é citado com o número da "lecture" em algarismo romano, e o número das seções é acompanhado da subseção (ex: "V, \$2.1" indica a quinta "lecture", seção \$2, denominada "goodnes as rationality", e a primeira subseção que ocupa as páginas 176 e 177 da edição utilizada).

2 Sandel localiza esta concepção de natureza humana nas partes da posição original: "a solução de Rawls é restringir a descrição das partes na posição original àquelas características que todos os seres humanos possuem enquanto seres racionais livres e iguais. Grosso modo, essas características são que cada um escolhe os seus fins e avalia os bens primárioscomo instrumentais para a realização de seus fins, independente de quais sejam. É assumido que essas características são comuns a todos os seres humanos enquanto tais e, neste sentido, elas são não-contingentes” (SANDEL, 1998, p. 39). Essa interpretação está equivocada. Quando Rawls descreve sua concepção de pessoa em "Kantian Constructivism in Moral Theory" (RAWLS, 1999a), ele diz que toda a posição original é construída de forma a representar as concepções de pessoa e sociedade bem ordenada. Ele diz que as partes descrevem apenas o aspecto racional da concepção de pessoa rawlsiana. A pessoa moral também é razoável, e esta característica é

doispontos, Curitiba, São Carlos, vol. 10, n. 1, p.61-81, abril, 2013 
representada no véu de ignorância. Sandel está equivocado, portanto, ao dizer que somente as partes representam as características da pessoa moral de Rawls.

3 “um segundo aspecto da liberdade [...] é que, enquanto pessoas livres, os cidadãos reconhecem uns aos outros como tendo o poder moral de possuir uma concepção de bem. Isto significa que eles não se veem como inevitavelmente ligados à persecuçãode uma concepção específica de bem e seus fins tal como eles seguem em um determinado momento. Ao contrário, enquanto cidadãos, eles se reconhecem como, em geral, capazes de revisar suas concepções em bases racionais e razoáveis. É considerado permissível aos cidadãos se distanciar de suas concepções de bem para investigar e avaliar outros fins.” (RAWLS, 1999, p. 331).

${ }^{4}$ Para argumentar que Rawls supõe uma concepção de "sujeito de possessão", Sandel citou a primeira passagem reproduzida acima. A segunda parte do texto, que faz a distinção entre identidade pública e não-pública e é descrita por Sandel como uma "resposta deológica com uma concessão e uma distinção”, aparece apenas na penúltima página da conclusão do seu livro (v. SANDEL, p. 62, p. 182).

${ }^{5}$ Para uma análise mais detalhada sobre o uso de abstrações no pensamento de Rawls, ver REIS, 2012, pp. 20-38, 107-118; 123-143.

\section{Referências bibliográficas}

FORST, R. 2010. Contextos da Justiça. Tradução de Denílson Luís Werle. São Paulo: Boitempo.

FREEMAN, S. 2007. Justice and the Social Contract. Essays on Rawlsian Political Philosophy. New York: Oxford University Press.

SANDEL, M. 1998. Liberalism and the Limits of Justice. Second Edition. New York, Cambridge: University Press.

RAWLS, J. 1996. Political Liberalism. New York: Columbia University Press.

RAWLS, J. 1999a. A Theory of Justice. Revised Edition. Cambridge: Harvard University Press.

RAWLS, J. 1999b. Fairness to Goodness. In: FREEMAN, S. John Rawls. Collected Papers. Cambridge: Harvard University Press.

RAWLS, J. 1999c. Kantian Constructivism in Moral Theory. In: FREEMAN, S. John Rawls. Collected Papers. Cambridge: Harvard University Press. 
REIS, F. A. 2012. Da teoria moral à filosofia política: uma investigação do pensamento de John Rawls. 152 f. Dissertação (Mestrado). Faculdade de Filosofia, Letras e Ciências Humanas. Departamento de Filosofia, Universidade de São Paulo, São Paulo. 
82

$\bullet$ 


\title{
Economia Política e as raízes da posição original em Rawls
}

\author{
Fabrício Pontin \\ fpontin@gmail.com \\ Southern Illinois University, Illinois, USA
}

resumo 0 impacto e a relevância da teoria econômica para o desenvolvimento de $A$ Theory of Justice são, frequentemente, deixados de lado na imensa literatura a respeito das obras de John Rawls. Ainda assim, entender os elementos de economia política na obra de Rawls é fundamental para a compreensão dos motivos pelos quais ele abandonará uma abordagem utilitarista para a filosofia política e, consequentemente, para nosso entendimento das principais questões que dão origem à noção de justiça como equidade. Este artigo tem dois objetivos principais: primeiramente, descrever a influência de John Stuart Mill, Kenneth Arrow e Vilfredo Pareto na virada metodológica encontrada na ideia de posição original; segundo, descrever os elementos históricos pressupostos para a compreensibilidade dos ideais rawlsianos. Concluirei com algumas observações que sugerem um complemento historicista e fenomenológico para as descrições ideais encontradas no liberalismo político tal como é entendido por Rawls.

palavras chave Economia Política; Liberalismo Político; Posição Original; Escolha Racional.

Em 1929, Wittgenstein apresentou, em Cambridge, uma conferência sobre ética. Essa seria a única vez que o autor dedicou-se a esse tópico. $\mathrm{O}$ artigo mostra a imensa dificuldade em estabelecer uma linguagem na qual poder-se-ia lidar com questões éticas e de constituição de valor. A "corrida contra os limites dentro dos quais nos encontramos" " descrito por Wittgenstein oculta um preocupação peculiar: afirmações sobre questões éticas são possíveis? Ou seja, essas afirmações podem ser consideradas verdadeiras ou falsas? Isso nos leva de volta à questão sobre o que nos permite

Recebido em 30 de janeiro de 2013. Aceito em 01 de março de 2013.

Texto traduzido para o português por Dr. WalterValdevino (Filosofia, UFRRJ).

doispontos, Curitiba, São Carlos, vol. 10, n. 1, p.83-101, abril, 2013 
dizer que um objeto "q" tem propriedades "z", "y" ou "a" que nos permitem falar daquele objeto como sendo "q", e, caso essas propriedades deixem de se aplicar a "q", se "q" deixaria de ser o caso. Isso é facilmente verificável quando lidamos com objetos físicos ou com fatos da natureza, em relação aos quais afirmações de "caso" podem ser, ao menos prima facie, fáceis de indicar. É verdadeiro que força é igual a massa vezes aceleração, é verdadeiro que um corpo permanece em repouso até que algo perturbe essa condição e é verdadeiro que a cor preta do teclado em que digito este texto é o resultado da interação de ondas de luz que possuem velocidade aproximada de $3.0 \times 10^{8} \mathrm{~m} / \mathrm{s}$. Mas essas afirmações estão reproduzindo leis da fisica, e temos uma linguagem particular para lidar com essas leis - claro que essa é uma linguagem imperfeita, mas mesmo com esse proviso em mente, dificilmente alguém encontraria uma hipótese que indicasse que a inércia não existisse. Mas o que podemos dizer em relação a julgamentos de valor?

Se as tradições alemã e francesa concentraram-se nas condições especulativas para a teoria moral e na conexão entre o moral e o legal, a modernidade inglesa e a americana são marcadas por um acentuado foco na economia. Talvez isso seja o reconhecimento dos limites da teoria moral: já que não podemos apreender completamente os processos de constituição de valor e identidade, poderíamos nos concentrar em como estabelecer preferências e em como essas preferências resultam em dinâmicas de troca de valor. Isso também leva ao reconhecimento de que a organização constitucional do dissenso social torna-se uma tendência irresistível na política europeia depois da Paz de Westphalia - e tal organização constitucional traz consigo a organização burocrática do capitalismo.

Nesse sentido, Rawls está certo, em 1974², quando decide concentrar-se nos elementos da política econômica no utilitarismo de modo a construir sua crítica aos modelos de vantagem comparativa da filosofia política. Isso tem dois motivos: primeiro, a confirmação de que, depois do reconhecimento da prevalência dos direitos, não há mais controvérsia no debate em relação a que valores devem ser considerados universais ${ }^{3}$; em segundo lugar, depois do surgimento da teoria liberal dos direitos, a teoria econômica é o único tipo de doutrina abrangente que precisa ser questionada em termos políticos: novamente, o foco é em como direitos devem ser implementados e não em por que devem ser implementados ${ }^{4}$. 
Não é coincidência que Rawls faça muitas de suas reflexões partindo das pressuposições construídas por Pareto e, depois, por Arrow ${ }^{5}$. E foi justamente Arrow que foi capaz de provar que o complexo sistema de Pareto para o equilíbrio social era possível, pelo menos matematicamente, em uma situação ideal. Mas ele também indicou discrepâncias matemáticas no desenvolvimento geral de um sistema democrático. Ou seja, mesmo em condições bastante mínimas, seria praticamente impossível, do ponto de vista da economia política, estabelecer uma fórmula matemática sólida para um sistema democrático.

Gostaria, agora, de desenvolver as condições, do ponto de vista da economia política, que permitirão a Rawls construir um núcleo metodológico para sua defesa das políticas liberais. Rawls descreve o processo de escolha social e preferências que leva ao desenvolvimento de sociedades liberais. Tal descrição ocorre de acordo com a teoria da escolha racional e a teoria utilitarista, que Rawls tenta superar com sua própria versão de uma descrição universalista e baseada em princípios a respeito da supremacia de direitos.

Nesse sentido, devemos entender quais elementos da teoria econômica são fundamentais para o desenvolvimento da magnus opus de Rawls. Enfrentar tais elementos permitir-nos-á identificar as principais questões encontradas por Rawls na teoria utilitarista. Tais questões, parece-me, não são de origem filosófica, mas econômica.

Tanto quanto diz respeito à economia política, todo o debate sobre preferências gira ao redor de uma única ideia desenvolvida por Stuart Mill: a noção de "critério de preferência para a decisão". No quarto capítulo de sua obra-prima Utilitarismo, Mill antecipa os duzentos anos seguintes de debate sobre escolha racional com uma simples sucessão de afirmações sobre preferências. Primeiro, Mill sugere que é possível preferir um prazer em relação a outro. Assim, se um prazer é visto como tendo uma ordem superior ao de outro, é razoável assumir que indivíduos que experimentam esses prazeres de ordem superior buscarão atividades e experiências que levem a esses prazeres. E eles irão, certamente, evitar atividades e experiências que farão com que esse prazer desejado cesse ou desapareça. Também é possível preferir evitar meios para alcançar um certo prazer (mesmo de ordem superior) se as circunstâncias levarem a tal desconforto que o prazer obtido se torne, nesse contexto, insignificante. 
Nesse sentido, se eu realmente gosto de sorvete de limão, buscarei experiências que me levem a obter sorvete de limão - ao invés de sorvete de chocolate, que eu não gosto. Entretanto, se as circunstâncias fizessem com que eu fosse torturado, ou me fizessem matar bebês jogando-os contra uma parede, ou me fizessem comer sorvete de chocolate para que eu pudesse comer sorvete de limão, então seria perfeitamente razoável preferir não obter sorvete de limão.

Assim, o que é fundamental para a própria possibilidade de conceber tais prazeres é que os indivíduos sejam capazes de desenvolver "hábitos de autoconsciência e auto-observação" ". Isso significa que uma decisão a respeito de preferências, particularmente as de alta ordem, têm de ser, de algum modo, uma decisão informada, ou seja, indivíduos que decidem com base em preferências estão tomando decisões com algum grau de consciência a respeito da cadeia causal que leva da experiência ao prazer, e são capazes de entender, pelo menos, algumas das intricadas sutilezas de tal cadeia causal. Além disso, Mill acredita que as pessoas têm preferências porque elas têm preferências. Ou seja, elas são afetadas apenas de modo marginal por fatores externos e vantagens circunstanciais (embora, como eu tenha mencionado, haja um proviso para certos meios para se alcançar um fim que poderia implicar em sofrimento ou desconforto de uma ordem superior àquela da preferência em vista).

\section{a) Alguns exemplos da Eficiência de Pareto nos processos de escolha}

Primeiramente, precisamos entender que a Eficiência de Pareto lida com dois cenários possíveis. Por um lado, temos um cenário no qual a estratégia dominante é dada de modo que cada agente que escolha possa ter as melhores opções possíveis à disposição (ou, pelo menos, que possa conceber essa possibilidade em uma situação ideal). Por outro lado, temos cenários nos quais a estratégia dominante não é dada dessa forma e as melhores escolhas desejáveis não estão à disposição dos agentes.

Assim, suponhamos que haja dois agentes escolhendo frutas em uma situação na qual 100 indica a escolha favorita, 50 é aceitável e 0 é inaceitável. 
Escolhas para o agente1
a) Uvas - 100
b) Pomelo - 51
c) Limão - 1

Escolhas para o agente2
a) Limão - 100
b) Pomelo - 51
c) Uvas - 1

Assim, evidentemente, em todos os casos nos quais 1 ou 2 estão escolhendo de modo independente um do outro e têm todas as três possibilidades sem qualquer espécie de interferência, eles escolherão independentemente (a), de modo a garantir a máxima satisfação. Esse é um cenário max-max.

Entretanto, em uma situação ideal na qual indivíduos estão escolhendo bens escassos, tais cenários são um pouco diferentes.

Suponhamos um cenário no qual diferentes escolha possíveis são dadas aos atores $\mathrm{A}(\mathrm{x})$ e $\mathrm{B}(\mathrm{y})$ :

\begin{tabular}{|l|l|l|l|}
\hline & & \multicolumn{2}{|c|}{$\mathrm{B}$} \\
\hline & & 1 & 2 \\
\hline \multirow{2}{*}{$\mathrm{A}$} & 1 & 100,1 & 50,50 \\
\cline { 2 - 4 } & 2 & 50,1 & 1,100 \\
\hline
\end{tabular}

Nesse caso, é factível que indivíduos optarão por sua escolha preferida (100), de modo a não prejudicar a escolhas possíveis para (B). Esse é uma Eficiência de Pareto fraca, ou seja, indivíduos, em uma situação ideal, podem escolher estados factíveis.

Ademais, isso pressupõe que os indivíduos não agirão de modo egoísta para garantir sua máxima satisfação, colocando os outros em uma situação desfavorável. Para Pareto, a gestão de recursos torna-se um fator chave, aqui, para evitar a agitação civil (mas essa é uma discussão totalmente diferente).

Portanto, para todos os conjuntos de possibilidades nos quais $\{a, b$, c) são apresentadas para agentes como escolhas possíveis, a Eficiência de Pareto nos dirá que a escolha razoável (para 1 e 2) é preferir (b), já que escolhas moderadas são mais propícias a levar a resultados eficientes tais como: 


$$
\begin{aligned}
& a-b<b-c \\
& -2 b<-a-c \\
& b<a / 2+c / 2
\end{aligned}
$$

Assim, se aumentarmos o número de situações sociais e escolhas sociais, o quadro aqui tornar-se-á cada vez mais complexo. Essa situação também supõe um cenário de equilíbrio não forçado (ou seja, ambas as partes podem alcançar uma situação social factível). Isso é o que chamamos de cenário max-mini. Uma característica interessante desse cenário é que, em termos de escolha social, ele implica que os agentes podem chegar a melhores resultados (a longo prazo) ao escolher preferências que são menos desejáveis de acordo com seus próprios critérios (ou seja, agir de modo egoísta pode significar irracionalidade econômica).

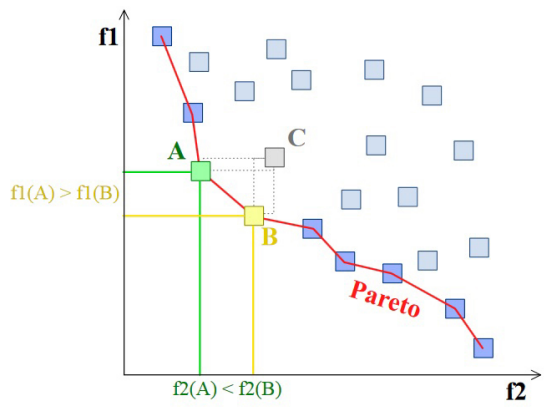

O gráfico acima oferece um exemplo de tal cenário. Considerando os blocos como escolhas possíveis, a maioria dos pontos de equilíbrio entre (f1) e (f2) ocorrerá na parte mais baixa do gráfico. Observe, desse modo, que dois desses estados disponíveis são desejáveis tanto para (f1) quanto para (f2) e são, portanto, "ótimos" em termos max-mini. Outros pontos podem ser um ponto de equilíbrio em termos econômicos (ou seja, há quantidade suficiente desses bens para ambos os agentes), mas a escolha desses bens implicaria que um desses agentes acabe em condições piores do que o outro no final do processo de escolha. Esse é o núcleo do "princípio da diferença" de Rawls. ${ }^{7}$

Pareto também concebe cenários similares nos quais tal distribuição de mercadorias não é possível. Nesse caso, o ponto de eficiência é aquele no qual o conjunto "menos pior" de escolhas favoráveis é oferecido ao 
maior número de agentes na situação ideal de escolha. Isso é chamado, em economia, de ponto de felicidade - também um cenário mini-max.

Finalmente, um último cenário é apresentado na situação ideal, no qual todos os bens disponíveis são ruins ou não estão à disposição (pense na época de pós-guerra na Alemanha, Japão ou Vietnã). Esse seria um cenário mini-mini.

Nesses dois últimos cenários, uma Eficiência de Pareto é impossível. Dada que ela é considerada um princípio da racionalidade econômica na maior parte da literatura do pós-guerra, qualquer cenário, enquanto tal, torna-se um ponto não desejável ou, se você preferir, um sistema irracional de distribuição.

\section{b) Uma teoria econômica da democracia}

Arrow, sob forte influência de Pareto, tentou controlar ainda mais os elementos do critério de Mill para a escolha. Primeiramente, ele defenderá que ter uma preferência significa somente que alguém é capaz de expressar uma hierarquia de valores ou de escolhas de acordo com os dois princípios gerais de conectividade e transitividade. ${ }^{8}$ Ter uma preferência, então, significa que é possível que (A1) possa expressar uma hierarquia e que (A2) mantenha a coerência interna de uma hierarquia de valores. ${ }^{9}$ É muito importante notar que Arrow não se importa com as motivações que estão por trás do processo de escolha de uma preferência. O que importa é que o indivíduo possa e expresse um conjunto consistente de preferências. Isso é verdade em relação ao modo pelo qual escolhemos nossos sabores favoritos de sorvete ou nossos candidatos favoritos em uma eleição. Qualquer agente racional, para Arrow, manter-se-á consistente em suas opiniões, por exemplo, quando diz preferir limão a laranja e laranja a melão, isso significa que ele preferirá limão a melão (de acordo com A2). Isso, certamente, é uma noção muito fraca de racionalidade ${ }^{10}$ na medida em que exige somente que o agente mantenha uma consistência mínima em sua própria expressão de preferências.

Mas como passamos de uma ordenação individual para uma ordenação social de preferências? 
Arrow chamará de "função do bem-estar social"11 o processo através do qual as preferências individuais são representadas em uma eleição. Os eleitores serão capazes de decidir sobre um número de mercadorias (objetos da escolha) que irão constituir um estado social (um conjunto possível de mercadorias) que representa ordenações individuais de preferências. A função do bem-estar social é tal que um conjunto de ordenações $(R)$ de eleitores diferentes será levado em consideração de modo que para quaisquer dois estados sociais $\mathrm{x}$ e y de uma dada ordenação social, R será obtido. ${ }^{12}$

Isso ocorre independentemente da expressão individual em relação a quaisquer tipos de preferências. A regra sobrepõe-se às preferências individuais de acordo com a vontade geral. Assim, percebo os perigos de sugerir que Arrow está seguindo uma concepção clássica de vontade geral, mas, de fato, uma vez que analisamos as condições sob as quais a função de bem-estar social opera, tornar-se-á cada vez mais claro que Arrow está se baseando em uma noção liberal clássica de democracia.

Para Arrow, devemos primeiramente perguntar quais são as condições que satisfazem a forma de um sistema democrático. Se pudermos organizar os critérios segundo os quais pensamos a democracia, qual seria o conjunto geral de regras que precisaríamos seguir para fazer com que uma eleição pudesse ser chamada de democrática ou para o estabelecimento de bem-estar social?

Arrow, em sua tese Social Choice and Individual Values ${ }^{13}$, afirma que uma (e talvez qualquer) definição plausível de democracia é incompleta. Isso significa, em termos primeiramente desenvolvidos por Gödel, que o conjunto de requerimentos estabelecidos de modo a chegar à conclusão de que "p é o caso" acaba levando a que " p é o caso". O ato de votar é importante, aqui, porque é o momento no qual indivíduos escolhem um certo conjunto de preferências sociais que estão representados em um candidato ou em uma proposta política. Se há algo profundamente paradoxal no ato de votar, então a ideia toda de democracia irá ruir, afinal de contas, mesmo formas diretas de representação pressupõem a existência de algum tipo de eleição.

Por um lado, é suficiente, para Arrow, que indivíduos expressem suas preferências individuais de acordo com os critérios de transitividade e conectividade. Por outro lado, ele insiste em um número de condições 
de razoabilidade para se obter uma constituição aceitável (nesse caso, uma eleição aceitável). Até então, sabemos que a função de bem-estar social será tão complexa quanto o número de estados sociais disponíveis, a multiplicidade de estados sociais escolhidos e o número de indivíduos.

Além disso, as condições nas quais os indivíduos votam precisam ser tais que um conjunto de "critérios de controle" seja estabelecido. Tais condições são:

(C1) Não-ditadura (ND): a função de bem-estar social deve levar em conta os desejos de vários indivíduos. Ela não pode simplesmente expressar as preferências de um único indivíduo.

(C2) Universalidade (U): para qualquer conjunto de preferências de voto individual, a função de bem-estar social deve abranger uma ordenação única e completa de escolhas sociais. Isso deve ocorrer de modo que resulte em uma ordenação completa de preferências para a sociedade (de acordo com A1) e, necessariamente, forneça a mesma ordenação toda vez que as preferências dos eleitores forem apresentadas do mesmo modo (de acordo com A2).

(C3) Independência de alternativas irrelevantes (IAI): alternativas irrelevantes não podem causar impacto em alternativas relevantes. Ou seja, uma mudança na expressão de um subconjunto irrelevante não pode influenciar a ordenação do subconjunto relevante - o movimento estratégico de valores irrelevantes buscando afetar os valores relevantes é, assim, evitado, assim como a incompletude do subconjunto relevante.

(C4) Monotonicidade (Mono): para todo conjunto individual de escolhas 'r' corresponderá uma ordem social 'R'. Qualquer melhoria em 'r' implica uma melhoria em ' $\mathrm{R}$ ' ou, na pior das hipóteses, a repetição do status quo ante. A uma melhoria em ' $r$ ' nunca poderá corresponder um declínio da ordenação social em ' $\mathrm{R}$ '. Um indivíduo não deverá votar contra uma proposta que ele deseja que seja aprovada de modo a promovê-la (de acordo com C2 e A2). Em outras palavras, os valores presentes em r serão mantidos em $\mathrm{R}$.

(C5) Não-imposição (NI): os indivíduos são livres para decidir sua ordem de preferência sem coação externa. Qualquer resultado é possível dentro de um dado conjunto no início de uma eleição, e qualquer ordenação é possível dentro desse conjunto. A função de bem-estar social tem um espaço irrestrito dentro de um conjunto possível de alternativas. 
Em teoria, Pareto indicou que qualquer distribuição de bens, em uma situação ideal, sempre significará que o ganho de um indivíduo (ou grupo social) causará uma perda para outro indivíduo (ou grupo social). Nesse sentido, processos de troca jamais serão uma situação da qual as partes se beneficiarão igualmente. Uma exceção ocorre quando as condições para um processo livre e informado de troca, no qual as partes podem expressar e negociar suas preferências com um mínimo de interferência, levam a um estágio no qual o ganho de um indivíduo não provocará perda para um outro. Pareto expressou a plausibilidade da noção de "mão invisível" do mercado que poderia ser capaz de mitigar o processo de perda e ganho sociais em um equilíbrio hipotético.

Arrow foi capaz de demonstrar que tal posição ideal, chamada de "primeiro princípio da economia de bem-estar", seria matematicamente possível em uma situação idealizada, dado que os indivíduos estariam em uma situação de "perfeita informação"14 e que certas condições para a ordenação de preferências estariam presentes. Tais critérios de escolha são semelhantes àqueles que analisei acima e também levam, mesmo que haja critérios bastante estreitos para a razão e a racionalidade na escolha, a cenários paradoxais em relação à função de bem-estar social. ${ }^{15}$ Observe-se que as condições de Arrow para a escolha são as mesmas condições que Pareto desenvolveu para sua ideia de eficiência e são, para Arrow, equivalentes a um critério de razoabilidade. ${ }^{16}$

Nesse sentido, o bem-estar social reproduz preferências individuais indiretamente mesmo que elas sejam expressas diretamente e também evita que questões irrelevantes tornem-se decisivas na definição da função de bem-estar social. Arrow não justificará seus princípios de ordem democrática mais detidamente. Seu argumento principal é que eles "pareçam sólidos" e estejam de acordo com a interpretação moderna sobre aquilo que é exigido para que uma democracia seja considerada como tal. Note que nenhuma dessas condições é suficiente sozinha para garantir a existência de um sistema democrático. Elas são necessárias conjuntamente para uma concepção suficiente de democracia - e observe que essa concepção suficiente se assemelha bastante à democracia constitucional que encontraremos na estrutura básica para a equidade institucional, depois, em Rawls.

Isso ocorre porque os indivíduos não agirão sem buscar um benefício individual, mesmo às custas dos outros, sem alguma espécie de marco 
regulatório ou rede de segurança. Em um sistema de oportunidades e preferências desiguais, os indivíduos não farão escolhas bem-ordenadas e previamente esperadas apenas para se submeter à elegância dos apontamentos matemáticos de Arrow. ${ }^{17}$ Talvez seja por esse motivo que o próprio Arrow concentrou-se em elementos relativos a valores no final de sua tese, observando que algum tipo de "diretriz" ética é necessária para a "solidez" da proposta democrática. ${ }^{18}$

\section{c) Cálculo de utilidade e justiça como equidade}

Nesse ponto, parece-me, Rawls vê os limites da teoria utilitarista ${ }^{19}$ e decide concentrar-se em uma abordagem kantiana da teoria política. Considerando apenas os elementos do cálculo de utilidade, não chegaremos, em Rawls, a um cenário no qual pudéssemos construir uma função de bem-estar social. Mas está claro que, sem Arrow, Rawls não poderia ter desenvolvido sua ideia de posição original nem poderia ter construído as condições para os princípios de justiça. ${ }^{20}$

Considero importante enfatizar, entretanto, que a doutrina do liberalismo é primeiramente entendida por Rawls, pelo menos em $A$ Theory of Justice, como um método. Isso significa que ideais como os de posição original, equilíbrio reflexivo e juízos morais bem ponderados não são, primeiramente, entendidos como questões fáticas, mas, ao contrário, como condições nominais para que uma doutrina particular de liberalismo que Rawls deseja se desenvolva.

A ideia de posição original inicia com uma suspeita compartilhada entre filósofos modernos contra a experiência pessoal enquanto justificativa da expressão de prioridades políticas. Parece que Rawls quer levar ainda mais longe o processo de despersonalização, criado por Kant no desenvolvimento do imperativo categórico como procedimento para validar a conduta. Afinal de contas, a posição original requer não apenas que as partes vão além daquilo que suas motivações sensíveis de conduta exigiriam: ela, na verdade, requer que as partes ajam como se não existissem motivações sensíveis para a conduta, história pessoal e assim por diante.

Esse exercício hipotético, então, colocaria os indivíduos em uma situação na qual, primeiramente, "preconceitos" ou "julgamentos" prévios a 


\section{4}

respeito da conduta e experiências prévias seriam abandonados quando os indivíduos entrassem no procedimento de escolha racional de valores para uma função de bem-estar social. Por que isso ocorre? Há duas razões principais: por um lado, temos a confiança de Rawls na condição kantiana de que a razão isoladamente, ou seja, o uso especulativo da razão, pode fornecer um quadro dentro do qual os valores são importantes; por outro lado, Rawls está se baseando profundamente em insights da teoria econômica.

A noção de uma posição original é, então, um requisito para a solidez do equilíbrio reflexivo em uma função de bem-estar social e esse equilíbrio reflexivo é uma imagem espelhada do já mencionado equilíbrio de Pareto, ou seja, o ponto no qual uma mudança não necessariamente implicaria uma situação em que o beneficio de um indivíduo (ou grupo) em uma função de bem-estar social não tornaria pior a situação de outro indivíduo (ou grupo). ${ }^{21}$

Gostaria, agora, de interrogar como se parecem os indivíduos na posição original. Considerando que Rawls estabelece o caráter hipotético de tal posição e que ela pertence ao âmbito da teoria ideal, acredito que a questão permanece válida: como se parecem os indivíduos na posição original hipotética?

Estariam esses indivíduos na posição original conscientes das potenciais consequências de suas escolhas de valores e teriam eles conhecimento sobre as condições futuras, por exemplo, de modo que não passar fome fosse preferível a passar e, portanto, políticas e princípios que evitassem a fome seriam preferíveis a políticas e princípios que fariam algumas pessoas passar fome, mas que poderiam fazer com que pessoas ricas realizassem seus sonhos mais extravagantes?

Nesse caso, faz sentido dizer que os indivíduos na posição original estão abandonando suas opiniões sobre a realidade social corrente quando alcançam a situação na qual estão fazendo escolhas sociais? Penso que isso é completamente contra-intuitivo, se seguirmos uma interpretação canônica do que o Rawls está propondo. Em uma interpretação puramente indulgente, bastaria conceber uma posição possível na qual os indivíduos, de alguma forma intuitiva, saberiam que condições mínimas de justiça social são preferíveis a condições de injustiça social.

Nesse sentido, insisto que, em seu núcleo, $A$ Theory of Justice está lidando com um método para a teoria política, na primeira parte, e esse 
método diz respeito às condições nas quais uma função de bem-estar social ideal em uma sociedade liberal é possível. Parte desse núcleo supõe que os indivíduos preferirão, intuitivamente, não sentir dor ao invés de sentir; que preferirão valores que potencialmente garantirão mais liberdade, e não menos. A outra parte do método, talvez menos persuasiva, lida com um tipo de afastamento da realidade social corrente quando se está concebendo essas preferências. Para Rawls, esse é um aspecto fundamental para eliminar prejuízos e vantagens potenciais com os quais os indivíduos possam estar "infectados" quando desenvolvem seus julgamentos de valor. Julgamentos de valor bem ponderados serão justificados, então, quando forem válidos dentro do escopo da posição original e potencialmente conduzirem a sociedade a uma posição de equilíbrio reflexivo, ou seja, uma posição na qual a expressão de preferências individuais por um política ou plano de vida não for potencialmente danosa para a possível expressão de outras preferências individuais.

"Razoável", então, rapidamente torna-se o adjetivo chave para Rawls, já que significa as considerações intuitivas que indivíduos hipotéticos são capazes de justificar do ponto de vista de uma posição original hipotética. Claramente, Rawls ainda acredita nos poderes da razão especulativa e na possibilidade de separar considerações de valor das contingências sociais. Do ponto de vista de uma teoria ideal, isso vai muito além do que imaginou Kant - mas Rawls acredita que a validade da tese kantiana tem apoio naquilo que a economia política nos diz sobre a competição e colaboração potenciais entre indivíduos em um modelo de trocas.

Entretanto, o modelo proposto por Pareto e adotado por Rawls pressupõe condições para esse processo de escolha: ele pressupõe um número de situações ideais e indivíduos ideais necessários para estabelecer uma certa posição de troca de valores ideais. Ele também pressupõe que os indivíduos não estão sob estresse de experiências prévias quando fazem escolhas "razoáveis" sobre suas preferências.

Essas são, certamente, pressuposições incrivelmente pesadas. Rawls sabe disso e não é uma coincidência que a segunda parte de $A$ Theory of Justice seja um denso tratado a respeito da importância de um quadro institucional que dará apoio aos indivíduos que serão capazes de escolher de tal forma. $\mathrm{Na}$ verdade, acredito que a segunda parte do livro nos fornece uma abordagem histórica de como uma função de bem-estar social 
ideal, do ponto de vista do liberalismo político, é possível. Se olharmos para o núcleo representado pela igual liberdade, pela justiça distributiva e pelos deveres e obrigações, estamos olhando para a história da formação do Estado moderno - que claramente toma forma a partir das revoluções constitucionais da Inglaterra, Estados Unidos e França -, e é dentro dele que Rawls vê o potencial para uma realização desse projeto.

Isso responderia à questão de "quem seriam os indivíduos na hipotética posição original": os indivíduos que estão no término do processo de secularização e emancipação representado pelo surgimento do Estado moderno.

Isso significa duas coisas: primeiro, que um Estado moderno e liberal é intuitivamente preferível a um Estado não moderno, não secular. Isso se dá principalmente porque as condições nas quais uma função de bem-estar social razoável é possível estão presentes apenas nos atuais e existentes Estados modernos. A segunda é que esse movimento, por causa de sua necessidade intuitiva, é defensável para Estados que ainda não são modernos, e que indivíduos nesses Estados se moverão em direção a posições mais liberais e seculares em relação a direitos - dadas as oportunidades para tal.

A segunda parte do argumento encontra-se nas afirmações universais sobre a personalidade moral, ou personalidade moral potencial, na terceira parte do tratado de Rawls: quando lidamos com a importância do bem, o senso de justiça e o papel da justiça, estamos lidando, pelo menos de acordo com Rawls, com características que são compartilhadas universalmente pelos seres humanos. É difícil argumentar contra a principal tese de Rawls: os ideais de liberdade de expressão e igual oportunidade podem muito bem ser contingências históricas peculiares a culturas ocidentais, com uma história sombria e complexa. Ainda assim, nossas razões para implementar esses direitos são sólidas e não temos razão para acreditar que outros não irão querer esses mesmos direitos, que eles não compartilham nossos sentimentos morais na medida em que eles estão ligados a princípios de justiça fundamentais (estar livre de escravidão, igual oportunidade entre indivíduos, possibilidades abertas para escolhas de vida etc.). A questão, então, é aumentar o alcance de tais direitos: se a doutrina da filosofia moderna criou um aumento sem precedentes na qualidade de vida em circunstâncias nas quais esses princípios foram efetivamente implementados, então por que não deveríamos tentar implementá-los em larga escala? Nesse sentido, a tese liberal torna-se irresistível em Rawls. 


\section{d) Em direção a uma crítica histórico-fenomenológica da escolha}

É interessante notar que a abordagem sugerida tanto por Arrow quanto por Rawls não faz economia no uso de "tipos ideais". Não considero que o uso de uma estrutura "ideal" para eleições, para processos de voto e para as condições para a democracia seja inteiramente uma coincidência. $\mathrm{Na}$ verdade, Arrow e Rawls são profundamente weberianos quando tentam estabelecer um modo através do qual uma estrutura ideal é realizável. Observe que Arrow dirá que as preferências individuais estão, de alguma forma, presentes nas escolhas sociais, e Rawls nos lembra bastante Weber quando escreve que valores e ideais são razoáveis na medida em que podem ser justificados pelos membros de uma sociedade, ao mesmo tempo em que não são realmente empíricos.

Entretanto, até onde sei, Rawls menciona Weber apenas uma vez em $A$ Theory of Justice. A menção está escondida no final do livro, ${ }^{22}$ em uma nota de rodapé, na qual Rawls acusa tanto Weber quanto Max Scheler (tanto quanto sei, essa é a única vez que Scheler é mencionado por Rawls) de fornecerem uma noção estratificante e rígida de vocação que não permite mudança ou mobilidade social e que não explica mudanças nas preferências e motivação sociais.

Ainda assim, sem uma concepção não estática de tempo dificilmente há qualquer chance de fazermos as preferências terem algum sentido. Há todo um conjunto de expectativas e representações que são pressupostas no momento da decisão. Constituímos valores em relação a nosso passado, nossa sociedade e nossa herança. Isso significa que alguém criado em um contexto racista sempre será racista? De forma alguma. Mas esse contexto terá grande influência na maneira pela qual esse indivíduo, por exemplo, resistirá ao racismo e constituirá sua própria perspectiva a respeito de como e porque o racismo é errado. Nesse sentido, a realidade dos valores para indivíduos ou grupos é construída socialmente, e não a partir de um rascunho, de acordo com o desejo do filósofo.

Nesse sentido, até mesmo motivações estratégicas precisam ser postas em contexto, assim como a interação que define tal estratégia. Por que minha atitude em relação aos outros me leva a não ter confiança em sua habilidade de colaborar ou compartilhar um determinado conjunto de valores comigo? 
Ao nos concentramos na determinação institucional dos tipos ideais, podemos tomar como garantida a interação social e ignorar um importante aspecto da "equação", ou seja: a constituição de tipos ideais está necessariamente conectada à construção histórica desses tipos ideias. Os processos de significação da estrutura de uma fenômeno cultural ou de uma concepção ideal é o resultado de uma disputa histórica que está ligada a um número de interpretações do fenômeno e do ideal, o que significa que não há tipo ideal institucional que não seja uma interação com sujeitos, e que não há sujeitos que estão fora da interação enquanto concebem um tipo ideal. Certamente, fazendo isso, estamos nos afastando do terreno de um historicismo weberiano e indo em direção a um estruturalismo fenomenológico.

Se somos capazes de reconhecer a importância de um equilíbrio reflexivo entre princípios de justiça ideais que são decididos de forma representativa, e uma pedagogia moral que informa a respeito das decisões sobre concepções de bem, precisamos também entender que esses processos não são estáticos nem ocorrem da mesma forma ou no mesmo ambiente. Refletir essa multiplicidade de concepções e o conflito entre elas é precisamente o que está em jogo para uma legislação escrita que busca reforçar a sociabilidade entre diferentes indivíduos - e entre diferentes socializações que vêm encarnadas neles.

1 "Running against the boundaries of our cage". WITTGENSTEIN. Lecture on Ethics. Disponível em http://sackett.net/WittgensteinEthics.pdf (último acesso: 28/08/2012).

${ }^{2}$ RAWLS, John. A Theory of Justice. (1974, repr. Cambridge: Harvard University Press, 1999).

3 “"J] ustice as fairness holds that, with regard to the constitutional essentials and questions of basic justice, and given the existence of a reasonably well ordered constitutional regime, the family of basic political values expressed by its principles and ideas have sufficient weight to override all other values that may normally come into conflict with them". RAWLS, Justice as Fairness: a restatement, p. 183. Também: "from the standpoint of moral theory, the best account of a person's sense of justice is not the one which fits his judgments prior to his examining any conception of justice, but rather the one which matches his judgments in reflective equilibrium". RAWLS, A Theory of Justice, p. 43.

${ }^{4}$ Ibid, p. 185

${ }^{5}$ Note-se que o desenvolvimento dos termos dos dois princípios de Justiça em $A$ Theory of Justice (p. 52-86) é baseado nos debates sobre a posição de equilíbrio de distribuição de bens 
na economia política. Tal debate é apenas possível a partir das reflexões de Pareto ( $A$ Theory of Justice, p. 58n) sobre equidade na distribuição de bens.

${ }^{6}$ RAWLS, John. Lectures on the History of Political Philosophy, p. 260.

${ }^{7}$ RAWLS, John. A Theory of Justice, p. 152.

${ }^{8}$ ( $\mathrm{x}, \mathrm{z}$ ) são candidatos, $\mathrm{P}=$ preferência, $\mathrm{I}=$ indiferença, $\mathrm{R}=$ preferência ou indiferença no contexto. Conectividade: para todos (os objetos de escolha no conjunto) $\mathrm{x}$ e y, tanto $\mathrm{x} R \mathrm{y}$ ou y R x. (A1); Transitividade: para todo x, y e z, xRy e yRz implicam xRz (A2). Assim, alternância ('ou') e conjunção ('e') de relações R representam ambas as propriedades de uma ordenação para todos os objetos de escolha. Nesse sentido, as possibilidades de ordenar preferências serão assim definidas: D1: xPy <-> $\sim$ (yRx) (de acordo com A1); D2: xIy <-> \{xRy e yRx) (de acordo com A2); D3: $x \mathrm{Ry}<->\sim \mathrm{yPx}$.

${ }^{9}$ ARROW. A difficulty in Social Welfare. In: ARROW. Collected Papers of Kenneth J. Arrow, Vol. I: Social Choice and Justice, pp. 26-7.

${ }^{10}$ Ver ARROW. Current Developments in the Theory of Social Choice. In:ARROW. Collected Papers of Kenneth J. Arrow, Vol. I: Social Choice and Justice, p. 163.

${ }^{11}$ ARROW. Social Choice and Individual Values, pp. 22-33.

12 Para Arrow: xPy indica "preferência social" por x em detrimento de y (x é selecionado ao invés de y, pela regra); xly é indica "indiferença social" entre x e y (ambos são ordenados igualmente de acordo com a regra) e xRy indica tanto "preferência social" de x em relação a y quanto "indiferença social" entre x e y (x é ordenado da mesma forma que y de acordo com a regra).

${ }^{13}$ ARROW, Kenneth J. Social Choice and Individual Values. New Haven:Yale University Press, 1963.

${ }^{14}$ Uma situação de perfeita informação é aquela na qual os indivíduos conhecem o conjunto possível de preferências disponível para todos os outros indivíduos em uma situação ideal. Em teoria dos jogos, isso significa que todos os possíveis movimentos de todos os jogadores em uma partida são visíveis para todos os outros jogadores (e que eles têm um entendimento similar a respeito do conjunto de regras do jogo). Em teoria econômica, isso significa que as partes conhecem os riscos e implicações de seus movimentos e são capazes de se mover livremente em direção a estados ou bens de sua preferência. Arrow está consciente da artificialidade dessa situação, mas é matematicamente possível conceber tal estado, e isso é suficiente para tornar viável o equilíbrio de Pareto - pelo menos de um ponto de vista econômico.

${ }^{15}$ As peculiaridades do assim chamado "paradoxo do voto" podem ser encontradas na tese de Arrow, Social Choice and Individual Values.

${ }^{16} \mathrm{Na}$ verdade, Arrow fazia parte do grupo de economistas que demonstraram a possibilidade do equilíbrio de Pareto.

${ }^{17}$ Daí, por exemplo, a necessidade do princípio da diferença em Rawls (ver Rawls. Justice as Fairness: A Restatement, pp. 158-9).

${ }^{18}$ A importância da ordenação social de preferências mínimas, ou consenso social, encontra-se em Arrow. Social Choice and Individual Values, pp. 81-6. Isso está ligado à importância de uma 
racionalidade coletiva que servirá como "controle" para o auto-interesse e a manipulação no processo democrático. Arrow claramente fica desconfortável quando lida com essas questões e a maior parte de seus insights sobre o tema são vagos e serão explorados de modo mais completo somente na apropriação que Rawls faz do equilíbrio de Pareto como equilíbrio reflexivo.

${ }^{19}$ Arrow prefere chamar sua teoria de ordenadora, ao invés de utilitarista. Esse é o resultado do que ele considera uma reapropriação maior da noção de utilidade e escolha de Mill. Para Arrow, seu critério de preferência é uma elaboração mais fraca e mais modesta do critério de decisão de Mill, e está baseado em um requisito mínimo para a eficiência da decisão: transitividade e conectividade. Na visão de Arrow, isso não é mais utilitarista no sentido proposto por Mill, mas ordenador, no sentido de que iguala razão e eficiência de escolha. Se uma escolha é eficiente (transitiva e conectada), então é uma escolha racional (ARROW. Some OrdinalistUtilitarian notes on Rawls' Theory of Justice. In: ARROW. Collected Papers of Kenneth J. Arrow, Vol. I: Social Choice and Justice, p. 98). Interessantemente, Arrow considera que essa noção de ordenação é totalmente compatível com a posição de Rawls. Isso não é surpreendente dado que Rawls também adota o modelo do equilíbrio de Pareto para seu equilíbrio reflexivo, e que ambos baseiam-se fortemente na noção de perfeita informação (embora de modos diferentes, como veremos adiante).

${ }^{20}$ Compare-se, por exemplo, a descrição do princípio de diferença em A Theory of Justice (pp. 61-3) e sua importância para um "sistema de cooperação" com o que acabei de analisar em Arrow e Pareto. Observe-se também que toda essa discussão ocorre nos mesmos moldes daquela feita por Mill em Political Economy e em Utilitarianism.

${ }^{21}$ Ver o parágrafo 16 de A Theory of Justice, e p. 65 de Justice as Fairness.

${ }^{22}$ Rawls, John. A Theory of Justice, p. 479, nota. Weber retorna, entretanto, em Justice as Fairness (p. 154, nota 29) em uma importante nota de rodapé que trata da inevitabilidade da "perda" e da tragédia humana com o surgimento de novas organizações econômicas.

\section{Referências bibliográficas}

1999. A Theory of Justice. Cambridge: Harvard University Press. .1983. Collected Papers of Kenneth J. Arrow, Volume I: Social Choice and Justice. Cambridge: Harvard University Press.

.1984. Collected Papers of Kenneth J. Arrow, Volume IV:The Economics of Information. Cambridge: Harvard University Press.

.2003. Justice as Fairness: A Restatement. Cambridge: Harvard University Press.

.1996. Political Liberalism. New York: Columbia University Press. 
.2008. Principles of Political Economy. New York: Oxford University Press (USA).

ARROW, Kenneth J. 1963. Social Choice and Individual Values. New Haven:Yale University Press.

BER GER, Peter; LUCKMANN, Thomas. 1967. The Social Construction of Reality. New York: Doubleday \& Company.

MILL, John Stuart. Utilitarianism. 2002. Indianapolis: Hackett Publishing Company.

PARETO,Vilfredo. 2007. Considerations on the Fundamental Principles of Pure Political Economy (Routledge Studies in the History of Economics). Routledge: London.

RAWLS, John. 2007. Lectures on the History of Political Philosophy. Cambridge: Harvard University Press.

RAWLS, John; FREEMAN, Samuel (ed.). 1999. Collected Papers. Cambridge: Harvard University Press.

WEBER, Max; HEYDEBRAND, Wolf (ed.). 1994. Sociological Writings. New York: Continuum.

WITTGENSTEIN, Ludwig. Lecture on Ethics. Disponível em http:// sackett.net/WittgensteinEthics.pdf (último acesso: 28/08/2012). 
102

$\bullet$ 


\section{Ética, economia e justiça: a escolha social no pensamento de Sen e Smith}

Fábio Creder - fcreder@homail.com

Universidade Estadual do Rio de Janeiro, Rio de Janeiro, Brasil

Luiz Bernardo Leite Araujo - lbaraujo@uerj.br

Universidade Estadual do Rio de Janeiro, Rio de Janeiro, Brasil

resumo Neste artigo pretendemos examinar a profunda e abrangente influência exercida pela obra de Adam Smith sobre o pensamento de Amartya Sen, especialmente no que concerne ao tema da justiça social, que permeia os escritos de ambos os autores. Primeiramente, analisaremos a revisão da obra de Smith, promovida por Sen, para refutar a interpretação ainda prevalecente que lança mão de determinados excertos de $A$ riqueza das nações como principal referência na defesa da desregulamentação dos mercados e na isenção do pensamento econômico de qualquer consideração por valores morais, demonstrando como Sen recorre às ideias de Smith para explicar o empobrecimento da economia ao afastar-se da ética. Em seguida, nos deteremos na contundente influência do pensamento de Smith sobre a crítica de Sen à teoria da escolha racional mediante sua peculiar formulação da teoria da escolha social, cuja importância foi justamente reconhecida ao the valer o prêmio Nobel de economia em 1998.

palavras-chave Amartya Sen; Adam Smith; Justiça social; Ética; Economia; Escolha Social

Amartya Sen, membro honorário da ilustre academia de economistas-filósofos (ao lado de Hume, Smith, Bentham, Mill e Marx, dentre os mais notáveis), proclama, com a urgência de um profeta, que as graves injustiças sociais do nosso tempo têm origem no trágico divórcio entre a ética e a economia; e anuncia, como se pregasse, que uma das prováveis causas deste evento remonta à má interpretação da obra de Adam Smith, o grande 
patriarca da economia política, cuja autêntica mensagem precisa, mais do que nunca, ser imediatamente professada.

Em uma série de artigos publicados em 2009, ainda no limiar da vigente (e recrudescente) crise econômica, Sen analisava os tão propalados dogmas do livre mercado, recorrendo à obra que resumiria a doutrina do seu suposto autor: Uma investigação sobre a natureza e as causas da rique$z a$ das nações (1776). Comumente, acredita-se que tais dogmas seriam os grandes desencadeadores da crise, e que, assim como o pensamento de Marx tornara-se obsoleto após o colapso do comunismo, o mesmo quiçá ocorrera com as ideias de Smith desde a aparente falência hodierna do capitalismo. Para Sen, no entanto, não poderiam estar mais equivocados os que pensam assim: malgrado a má fama que lhe foi injustamente atribuída, Smith não endossaria a ideológica versão "neoliberal" da doutrina do livre mercado, e já é quase passado o tempo de valer-nos da preciosa constatação do quanto as suas ideias nos podem oferecer soluções, não só para a presente crise financeira mundial, mas também para muitas das graves injustiças sociais do nosso tempo.

Veremos que, para Sen, a crença segundo a qual um capitalismo eficiente consistiria em um sistema baseado em um mercado totalmente livre e autorregulado é fatalmente supersticiosa e deveras incompatível com uma interpretação adequada do que Smith escreveu sobre o alcance e os limites da economia de mercado. Não seria de um novo capitalismo que o nosso tempo precisa, mas de um retorno às suas raízes, nomeadamente às ideias do fundador da economia moderna, que, segundo Sen, era muito mais sábio do que os seus influentes intérpretes (e falsos discípulos) nos tentaram fazer crer. ${ }^{1}$

Sen demonstra que dificilmente pode-se extrair da pioneira análise smithiana do funcionamento da economia de mercado uma teoria que estabeleça a sua suficiência. Ao contrário, Smith destacou o papel crucial de uma multiplicidade de valores sociais na escolha dos comportamentos, além da função reguladora imprescindível das instituições.

Como veremos, a fonte dos equívocos hermenêuticos cometidos pelos principais intérpretes de Smith provavelmente reside no fato de expandirem a sua constatação, bastante restrita, de o motivo subjacente às relações comerciais ser o autointeresse, para outras esferas normativas do comportamento. Sendo bastante evidente que as pessoas comerciam movidas pelo 
próprio interesse, segundo Sen, era igualmente óbvio, para Smith, que uma economia saudável carece de outros valores, como, por exemplo, a confiança mútua, para funcionar de maneira eficiente. ${ }^{2}$ Esse tipo de confiança, entretanto, nem sempre existe, e ao explicar claramente as razões deste fato, Smith forneceu elementos relevantes para a compreensão da presente crise.

Como Sen observa ironicamente, as pessoas têm hoje as mesmas razões que sempre tiveram para recorrerem ao comércio. Todavia, devido aos receios causados pela perda de confiança, o que agora lhes falta é oportunidade. As consequências de longo alcance da desconfiança nos mercados, que contribuíram para o surgimento da crise e têm impedido uma expansão coordenada do crédito, tornando tão árdua a recuperação da economia mundial, não causariam surpresa a Smith: ao contrário, corroborariam a sua hipótese segundo a qual os motores do comportamento econômico são muito mais variados do que supunha, por exemplo, Mandeville, para quem o egoísmo seria a única explicação adequada para todas as questões possíveis sobre a natureza humana. ${ }^{3}$

Conquanto soe surpreendente, apesar do esforço empreendido para explicar e defender o papel construtivo do mercado, Smith preocupava-se profundamente com a incidência da pobreza, do analfabetismo e da privação relativa, que podem persistir a despeito do funcionamento eficiente de uma economia aberta. Ele não só era um defensor do papel do Estado na realização das funções sociais de cujo exercício o mercado se eximia (como a promoção do acesso universal à educação e o alívio da pobreza), como defendeu que as escolhas institucionais atendessem a cada problema eventualmente surgido, ao invés de aderir de modo definitivo a alguma fórmula fixa, como sempre deixar ao mercado o livre seguimento do seu curso (SEN, 2009d).

Neste artigo pretendemos analisar a profunda e abrangente influência exercida pela obra de Adam Smith sobre o pensamento de Amartya Sen, especialmente no que concerne ao tema da justiça social, que permeia os escritos de ambos os autores. Primeiramente analisaremos a revisão da obra de Smith, promovida por Sen, para refutar a interpretação, ainda prevalecente, de $A$ riqueza das nações, que tem sido amplamente usada para justificar a defesa da desregulamentação absoluta dos mercados e a isenção do pensamento econômico de qualquer consideração por valores morais, 
e demonstraremos como Sen recorre às ideias de Smith para explicar o empobrecimento, e mesmo a perda de eficiência, da economia ao afastar-se da ética. Em seguida nos deteremos na decisiva influência do pensamento de Smith sobre a crítica de Sen à teoria da escolha racional através da sua característica formulação da teoria da escolha social.

\section{II}

Em 2009, em uma palestra ministrada na Universidade de Glasgow por ocasião das celebrações pelos 250 anos da publicação da Teoria dos sentimentos morais (1759), Sen reitera a mensagem que vinha proclamando desde o início da década de 1980, mas que nunca fora tão oportuna quanto quando o capitalismo começava a soar os estertores de uma agonia que tem perdurado: muitas das ideias avançadas na obra então celebrada, malgrado a sua profunda relevância para as necessárias meditações contemporâneas sobre ética e economia, e para uma compreensão abrangente e, portanto, adequada do pensamento de Smith, têm sido atualmente subestimadas. Na economia, por exemplo, as investigações pioneiras de Smith transcenderam a mera explicação das causas e dos modos de funcionamento do dinamismo da economia de mercado, ou a suficiência do interesse próprio nas relações comerciais: elas também consideraram o papel crucial de motivações morais mais amplas, assim como de determinadas instituições, para a eficácia e a viabilidade da atividade econômica em geral; e, na ética, o conceito de espectador imparcial, proposto por Smith na Teoria dos sentimentos morais, contribuiu para uma compreensão mais plena das exigências da justiça, designadamente da imparcialidade em relação a interesses paroquiais (SEN, 2010a). Tais contribuições influenciaram de modo decisivo o pensamento político e econômico de Sen, sobretudo a sua teoria da escolha social.

Ainda na palestra sobre Adam Smith e o mundo contemporâneo, Sen menciona dois tópicos das investigações do patriarca da economia moderna que, além de ilustrarem a complexidade do seu pensamento, ainda demonstram o seu reconhecimento do caráter indissociável da relação da economia com a ética e a importância da psicologia moral para a análise do comportamento econômico. $\mathrm{O}$ primeiro tópico concerne à 
impossibilidade de se pensar adequadamente o tema da pobreza sem considerar um dos seus aspectos mais sutis e relevantes: a desigualdade. Com efeito, a renda e os recursos necessários para alguém obter os mesmos funcionamentos e capacidades mínimos continuam a crescer com o progresso total da economia da sociedade a que pertence e o aumento da renda das outras pessoas do seu convívio social. Como se infere facilmente do comportamento econômico dos habitantes das grandes cidades, permanentemente sob a égide onipresente do consumismo, o senso de dignidade de uma pessoa pode ser gravemente afetado pela condição econômica exibida pelos demais membros da sua comunidade. Smith dedicou uma porção substancial da sua análise dos sentimentos morais à vaidade, como um dos principais fatores definidores dos modos como as relações sociais são estabelecidas e modificadas. Os efeitos nocivos da privação não se limitam, portanto, à falta de meios de subsistência, mas se estendem aos danos causados à autoimagem do sujeito ao comparar-se aos seus pares. A pobreza, em qualquer uma das suas modalidades, absoluta ou relativa, é igualmente capaz de infligir sofrimento físico ou psíquico às suas vítimas. (Este tópico, sobre a chamada "privação relativa", foi, provavelmente, determinante na elaboração por Sen da "abordagem das capacidades").

O outro tópico mencionado por Sen, trata da identificação feita por Smith, da influência destrutiva dos que ele chamava de "pródigos e projetores" (aos quais hoje chamamos de especuladores). O mero fato de Smith preocupar-se com os efeitos nocivos das atividades promovidas por esses indivíduos, por assim dizer, extraordinariamente autocentrados, é indício suficiente da sua preocupação com os limites da capacidade do mercado alcançar um justo equilíbrio a despeito da ausência de qualquer regulamentação imposta pela sociedade.

Ao celebrar a filosofia moral de Smith, Sen enfatiza ainda mais o equívoco da interpretação corrente da sua obra (segundo a qual Smith preconizaria a liberdade absoluta de comércio como a única medida capaz de promover a excelência do funcionamento do mercado, e a obtenção de lucro como a única motivação necessária aos contratantes), notando duas proposições cruciais enunciadas na Teoria dos sentimentos morais: a primeira, de caráter epistemológico, afirma que os indivíduos não são exclusiva e invariavelmente guiados pelo interesse próprio (ou, sequer, pela prudência); enquanto a segunda, concernente à razão 
prática, sugere haver boas razões para se encorajar motivos outros que a mera busca da obtenção de vantagens pessoais. Como veremos, a "teoria da escolha racional”, que há muito encanta uma legião de economistas influentes, atribui a Smith os seus rudimentos e endossa a interpretação corrente da sua obra, baseada em uma leitura superficial de $A$ riqueza das nações e ignorante dos elementos essenciais da sua psicologia moral, expostos na Teoria dos sentimentos morais. Em suma, os adeptos da teoria da escolha racional creem que a busca da satisfação do próprio interesse é a única atitude inteligente e racional que os seres humanos são capazes de adotar, e que, portanto, todas as relações econômicas baseiam-se neste princípio. O seu grande mote está resumido no seguinte excerto de $A$ riqueza das nações (que, descontextualizado e mencionado ad nauseam, parece autorizar as interpretações correntes):

Não é da benevolência do açougueiro, do cervejeiro e do padeiro que esperamos o nosso jantar, mas da consideração que eles têm pelos próprios interesses. Apelamos não à humanidade, mas ao amor-próprio, e nunca falamos de nossas necessidades, mas das vantagens que eles podem obter. (SMITH, 1979, I, I.ii.2, p. 26-27).

\section{III}

O problema da má interpretação do pensamento de Smith já há muito preocupava Sen, que começou a abordá-lo em profundidade na segunda metade da década de 1980, designadamente no artigo Adam Smith's Prudence, de 1986, e no livro On ethics and economics, de 1987; portanto, bem antes que as consequências de tais equívocos fossem evidenciadas pela atual crise econômica. ${ }^{4}$

Em Adam Smith's Prudence, Sen protesta claramente contra a depreciação do legado de Smith pelos seus intérpretes, alegando que, malgrado a complexidade de $A$ riqueza das nações, a maioria das vezes em que se a menciona é para transformar em slogan algum excerto de um colorido retórico mais acentuado (como o tema da "mão invisível" e a "passagem do açougueiro, do cervejeiro e do padeiro"), e assim valer-se da autoridade do autor para justificar posições ideológicas marcadas por um "extremismo conservador”, que não lhe fazem qualquer justiça. O propósito 
do artigo de 1986 é, basicamente, o de demonstrar que a compreensão de Smith da natureza humana não é simplória e redutora, mas complexa e plural, e abarca desde a prudência (que Sen tem o cuidado de distinguir claramente do mero egoísmo) à simpatia. O caráter cooperativo de que o ser humano é dotado, o qual lhe fornece motivos outros para agir que não o próprio interesse, não pode ser subestimado por quem o pretenda compreender e às suas relações, sejam estas meramente sociais ou econômicas. $\mathrm{Na}$ esteira de Hume, Smith não cometeu o erro de ignorar a riqueza psicológica da humanidade, e justamente por isso, foi capaz de uma profunda e pioneira compreensão do comportamento econômico.

No ano seguinte, em On ethics and economics, Sen aprofunda a sua análise da obra de Smith, demonstrando que dela não se pode inferir a premissa que infelizmente tem servido de alicerce para a economia moderna, qual seja a de que o egoísmo é a única motivação do comportamento humano. Sen admira-se que o pensamento econômico tenha evoluído de maneira a tornar essa concepção tão acalentada, porquanto "a economia supostamente ocupa-se de pessoas reais", sendo, pois, "dificil crer que tais pessoas possam ser totalmente indiferentes ao alcance do autoexame induzido pela questão socrática 'Como devemos viver?'”. Sen, portanto, indaga: "As pessoas estudadas pela economia podem mesmo ser tão insensíveis a essa questão flexível e ater-se exclusivamente à impassibilidade rudimentar a elas atribuída pela moderna economia?”. Ele também se surpreende com o "contraste entre o caráter conscientemente 'não ético' da economia moderna e sua evolução histórica, em grande medida, como um ramo da ética." (SEN, 1987, p. 1-2).

Com efeito, Sen sugere que a economia teve duas origens diversas, uma concernente à ética e a outra, em seus termos, à engenharia. A primeira remonta à Ética a Nicômaco e à Política de Aristóteles, cuja abordagem envolve dois temas cruciais para a economia: o problema da motivação humana, associado à questão "Como devemos viver?"; e a avaliação da realização social, que não se contenta em satisfazer a eficiência e a realização pessoal, mas preocupa-se com o bem-estar da comunidade. A segunda origem da economia, por sua vez, relacionada à abordagem engenheira, se caracterizaria por "ocupar-se de questões primordialmente logísticas", em vez de dos fins supremos e de questões éticas. "Considera que os fins são dados muito diretamente, e que o objetivo do exercício é encontrar os 
meios apropriados de atingi-los. O comportamento humano nessa abordagem baseia-se tipicamente em motivos simples e facilmente caracterizáveis." (SEN, 1987, p. 4).

Sen reconhece a relevância das duas abordagens, mas o que o motivou a dedicar-se ao exercício laudatório da ética foi a sua gradual e substancial diminuição de importância na economia moderna. Segundo ele, a metodologia da chamada "economia positiva" não apenas se teria esquivado da análise econômica normativa, como teria ainda deixado de lado "considerações éticas complexas, que afetam o comportamento humano real, e que, do ponto de vista dos economistas que estudam esse comportamento, são primordialmente fatos e não juízos normativos" (SEN, 1987, p. 7). O distanciamento crescente entre a economia e a ética teria empobrecido substancialmente a economia moderna, que seria mais produtiva se incluísse em suas análises as considerações morais que moldam o comportamento e o juízo humanos.

Um dos pontos mais interessantes de On ethics and economics é a análise do papel primordial que a hipótese de o "comportamento racional" se reduzir ao egoísmo tem desempenhado na economia moderna: o homo sapiens seria, por excelência, um homo economicus, pertencendo a sua natureza o predicado de ser, simultaneamente, racional e egoisticamente motivado. A primeira observação de Sen acerca do papel fundamental dessa premissa da economia moderna aponta para o grave equívoco de equivalê-la a uma descrição do comportamento real. Um pressuposto assim tão frágil é insuficiente para sustentar uma previsão de qual conduta será efetivamente adotada. Com efeito, conquanto se admitisse estar correta a caracterização do comportamento racional tradicionalmente adotada pela economia, nenhuma ilação lógica tornaria forçoso admitir que as pessoas devessem, sempre e de fato, se comportar dessa maneira. Aliás, pode-se facilmente constatar quão amiúde elas não o fazem. Como o coloca Sen, "Os tipos friamente racionais podem povoar os nossos manuais, mas o mundo é mais rico." (SEN, 1987, p. 11).

O problema, portanto, reside menos na identificação do comportamento racional com o comportamento real do que na caracterização do comportamento racional em termos tão excessivamente estritos quanto os da mera maximização do autointeresse. Obviamente não se trata de negar que esta seja uma atitude racional (é evidentemente plausível 
considerar a satisfação das próprias necessidades e vontades uma atitude razoável), mas sim de negar que tudo quanto não equivalha a isso seja irracional. O homem certamente é movido por motivos egoístas, mas frequentemente se deixa mover por outras razões. Valoriza e promove a realização de objetivos que, ao menos aparentemente, não lhe oferecem qualquer vantagem material (quiçá de outra sorte, mas benefícios imateriais não se inseririam propriamente na esfera do egoísmo que se tem em conta nas análises econômicas tradicionais que Sen pretende objetar).

Mesmo que, a título de argumento, concedêssemos que o ser humano médio, de fato, sempre maximiza o autointeresse, para Sen, a ideia de a racionalidade requerer a maximização do autointeresse não procede. Reconhecer a realidade do egoísmo universal talvez seja meramente um equívoco, mas considerá-lo um requisito de racionalidade, segundo Sen, é patentemente absurdo (SEN, 1987, p. 14). Evidentemente o oposto tampouco é plausível: salvo talvez raros santos e loucos, os seres humanos não agem todos sempre altruisticamente; se assim o fosse não haveria comércio, de modo que:"A verdadeira questão indaga se há uma pluralidade de motivações ou se apenas o autointeresse move os seres humanos". Ademais, como ele destaca, "o contraste não se dá necessariamente entre o autointeresse, de um lado, e algum tipo de preocupação geral por todas as pessoas, de outro." (SEN, 1987, p. 19).

Sen considera enganosa a tradicional dicotomia egoísmo/utilitarismo, designadamente porque o denominado "comportamento comprometido" é condição de possibilidade da atuação intermediadora entre o indivíduo e a sociedade, realizada por determinados grupos que promovem, mediante a lealdade de seus membros, a composição de conflitos de interesses que sejam apenas parcialmente conflitantes (também sendo, portanto, em alguma medida, convergentes). Conquanto sacrifiquem alguns interesses puramente pessoais, tais membros, simultaneamente, obtêm a satisfação de algum objeto importante do seu autointeresse.

"A mistura de comportamento egoísta e altruísta é uma das características importantes da lealdade de grupo, e essa mistura pode ser observada em uma grande variedade de associações de grupo, desde as relações de parentesco e comunidades aos sindicatos e grupos de pressão econômica." (SEN, 1987, p. 20). 
Neste contexto, dois aspectos comportamentais precisariam ser distinguidos, os quais se podem resumir nas seguintes questões: As pessoas de fato comportam-se de modo exclusivamente egoísta? Se o fizessem alcançariam algum êxito como, por exemplo, eficiência econômica? Embora seja corrente atribuir a Adam Smith respostas afirmativas para ambas as questões, Sen ressalta que há poucos indícios de que ele realmente o faria.

É bem verdade que Smith reconhecia a influência exercida pela prudência sobre a conduta da maioria dos indivíduos. E, de fato, a promovia como virtude. Entretanto, ele não chamava de prudência o que chamamos de egoísmo, e sim de amor-próprio. Para Smith, o conceito de prudência incluía o de autodomínio. Sua teoria é francamente devedora dos estoicos, que não concebiam o homem como ente isolado, mas membro indissociável da vasta comunidade da natureza, em cujo benefício deveria sacrificar as suas satisfações egoísticas. Esse é, portanto, o contexto em que se deve compreender o sentido do termo prudência em Smith, que embora fosse considerada uma virtude útil ao indivíduo, estava necessariamente vinculada a outras virtudes úteis aos outros membros da sociedade, como "humanidade, justiça, generosidade e espírito público", como notara em sua Teoria dos sentimentos morais (SMITH, 1976, p. 190).

Sen enfatiza que, além da prudência, Smith defendeu, especialmente, a simpatia. Esse fato, porém, há muito vem sendo esquecido pelas mais proeminentes correntes da economia. Embora seja verdade que as transações econômicas, o funcionamento do mercado e as razões subjacentes à divisão do trabalho estejam fundamentados na mútua obtenção de vantagens, Smith não defendeu que a prudência fosse suficiente para a eficiência do comércio ou a manutenção de uma boa sociedade: na verdade, defendeu o oposto disso. Sen recorda que Smith criticou Epicuro, por exemplo, justamente por ter concebido a virtude exclusivamente em termos de prudência (cf. SMITH, 1976, p. 294-300). Quanto ao professor de filosofia moral e economista pioneiro do século XVIII,

"A defesa do comportamento autointeressado aparece em contextos específicos, particularmente relacionados a várias barreiras burocráticas da época e a outras restrições a transações econômicas que dificultavam o comércio e atrapalhavam a produção.” (SEN, 1987, p. 25). 
O aspecto da produção é especialmente importante para Sen, porque uma das áreas em que a análise econômica de Smith teria sido mais mal interpretada, e, assim, causado consequências terrivelmente danosas, é a da fome. Smith defendeu o livre comércio não simplesmente pelo enriquecimento das nações, mas, sobretudo, por produzir um aumento exponencial da produção de víveres. O empobrecimento das nações implicava o aumento da pobreza e da fome.

Ademais, se é verdade que Smith geralmente se opunha a restrições ao livre comércio, isso, entretanto, não implicava que ele, ao contrário de Malthus, desaprovasse a ajuda aos pobres em tempos de carestia, nem que desconsiderasse exceções à regra do livre mercado em favor dos desprivilegiados. Em $A$ riqueza das nações, ele advertira quanto à possibilidade de algum processo econômico envolvendo o mercado gerar surtos de fome coletiva que não fossem decorrentes de escassez provocada por um declínio na produção de alimentos. As verdadeiras causas da penúria e da fome, neste caso, seriam o desemprego e os baixos valores reais dos salários. Conquanto Smith, em condições ordinárias, se opusesse à regulamentação do comércio, ele sugeriu a necessidade da elaboração de políticas públicas que efetivamente respondessem aos problemas que situações extraordinárias colocavam aos mais pobres. (SMITH, 1979, I, I.viii, p. 82-104; SEN, 1987, p. 25-28). ${ }^{5}$

A influência da complexidade do pensamento moral, político e econômico de Adam Smith foi, portanto, determinante na elaboração do pensamento filosófico de Amartya Sen. Na próxima seção, analisaremos como essa influência se exerceu, designadamente na formulação, bem como na posterior exposição na obra seniana $A$ ideia de justiça, de sua célebre teoria da escolha social, relacionando-a com o pensamento moral e político smithiano.

\section{IV}

Em 1998, a Real Academia Sueca de Ciências outorgou a Sen o Prêmio Nobel por "suas contribuições para a economia do bem-estar", dentre as quais foi justamente enfatizado na exposição dos motivos da outorga, além da "restauração de uma dimensão ética da economia e disciplinas 


\section{4}

relacionadas", o seu empenho no "desenvolvimento e aplicação da teoria da escolha social" (NOBEL, 1998). ${ }^{6}$

Certamente, a preocupação de Sen com o tema da justiça social foi o motivo que subjazeu aos estudos que lhe permitiram formular a sua teoria da escolha social. Com efeito, todas as sociedades que tenham adotado, em alguma medida, ideais democráticos e igualitários estão necessariamente confrontadas à necessidade de tomarem decisões coletivas, especialmente no que concerne à determinação dos critérios segundo os quais os modos de distribuição de recursos escassos entre os seus membros serão definidos. Mas, haverá uma maneira ao mesmo tempo justa e teoricamente plausível de se agregar preferências individuais que se traduzam em valores vantajosos para toda a sociedade, e não apenas para alguns de seus membros, ou quiçá a maioria?

A teoria da escolha social dedica-se a analisar sistematicamente as questões ao mesmo tempo cruciais e espinhosas suscitadas pela necessidade de se conceberem regras decisórias em uma sociedade democrática. Confluindo teoria política, ética e economia, Sen dedicou-se a investigar e aprimorar algumas das mais importantes aplicações desta teoria, quais sejam a mensuração da desigualdade de renda em determinada sociedade, a comparação da distribuição de bem-estar entre várias sociedades, e a definição de critérios a partir dos quais seja possível reconhecer se a pobreza foi ou não mitigada após a realização de alguma medida adotada para esse fim. Se fosse possível, e se de fato houvesse um acordo geral, as escolhas feitas pela sociedade não seriam controvertidas. $\mathrm{O}$ desafio surge quando diferentes interesses precisam ser agregados em decisões que afetem a todos.

Embora a regra da maioria seja o método mais comum de tomada de decisões coletivas em uma sociedade democrática, há muito se têm demonstrado suas graves deficiências, especialmente a possibilidade de a maioria suprimir a expressão social da minoria. Este último fato teria sido demonstrado por Kenneth Arrow, através do seu célebre Teorema da impossibilidade. As conclusões de Arrow, comentadas mais adiante, indicaram severas limitações nos resultados passíveis de serem obtidos através da tomada coletiva de decisões. O seu teorema afigurou-se um obstáculo insuperável para qualquer progresso na esfera normativa da economia por duas décadas. Como agregar preferências individuais a decisões coletivas, e como comparar e avaliar satisfatoriamente diferentes estados sociais? 
No final dos anos 1960, as pesquisas de Sen inauguraram uma nova esperança de solução dos problemas enfrentados pela teoria da escolha social. Sua obra Collective choice and social welfare (1970), e as que se seguiram nos anos 1970 e 1980, tiveram um impacto considerável sobre as pesquisas acadêmicas em economia, renovando o interesse dos pesquisadores por importantes questões de justiça e bem-estar social.

No âmbito do nosso propósito neste artigo, cabe a pergunta: a influência de Adam Smith sobre Sen estende-se à sua elaboração da teoria da escolha social? Uma resposta afirmativa, inicialmente, se basearia, sobretudo, na evidência de que a preocupação de Sen em conciliar economia e justiça social, como vimos, é devedora das suas leituras de Smith, particularmente da sua crítica ao reducionismo implícito na ideia do homo economicus. Uma dificuldade de se explorar mais claramente essa relação reside no fato de grande parte das contribuições de Sen à teoria da escolha social ter sido axiomática. Mas, em seu livro de 2009, Sen abandona o formalismo e oferece indícios de que essa influência foi ainda mais abrangente do que se pode inferir das muitas menções que fizera a Smith em seus textos até então publicados.

Sen trata especificamente da teoria da escolha social no quarto capítulo de The idea of justice (2009a), intitulado Voz e escolha social, onde reapresenta o conteúdo da sua Nobel Lecture de 1998, nomeada justamente A possibilidade de escolha social.

Embora discussões sobre ética e política remontem a Aristóteles, a exploração dos procedimentos formais das decisões públicas e de seus (frequentemente ocultos) pressupostos normativos subjacentes começou muito mais tarde. A teoria da escolha social seria uma das maneiras de abordar essas questões. Como disciplina sistemática, ela adquiriu autonomia no final do século XVIII, graças ao trabalho pioneiro de dois matemáticos franceses: Jean-Charles de Borda e o Marquês de Condorcet, os quais, ao abordarem em termos matemáticos o problema de se obter avaliações agregadas baseadas em prioridades individuais, inauguraram as investigações sobre o tema da escolha social.

Segundo Sen, o que motivava esses primeiros teóricos era a necessidade de se evitar tanto a arbitrariedade quanto a instabilidade nos procedimentos de escolha social. O seu trabalho concentrava-se no desenvolvimento de uma estrutura de decisões racionais e democráticas para um grupo, 
considerando as preferências e interesses de todos os seus membros. Todavia, as suas investigações normalmente obtinham resultados pessimistas. Condorcet, por exemplo, em seu conhecido "paradoxo", demonstrou que a regra da maioria poderia ser totalmente inconsistente, porquanto as preferências coletivas são intransitivas, isto é, as vontades que compõem a maioria podem conflitar umas com as outras, já que tal composição é heterogênea. (SEN, 2009a, p. 92).

Ao longo do século XIX empreenderam-se inúmeras tentativas de solucionar o problema, mas foram todas igualmente malfadadas. Durante a década de 1950, Kenneth Arrow (outro vencedor do prêmio Nobel) retomou as questões de Condorcet e Borda e elevou as investigações sobre a escolha social a um novo patamar. No clássico livro Social choice and individual values, preocupado com as inconsistências das decisões coletivas, Arrow notou a necessidade de se explicitar quais condições mínimas de racionalidade deveriam ser satisfeitas para que um procedimento decisório social pudesse ser admitido. Após a mais profunda análise feita até então, Arrow acabou sendo obrigado a concluir que nenhum procedimento de escolha social que se pudesse razoavelmente descrever como racional e democrático era capaz de satisfazer as condições mínimas exigidas de uma escolha social para que se a considerasse sensível aos interesses individuais dos membros de uma sociedade. Apenas uma ditadura poderia evitar inconsistências, mas isso, obviamente envolveria um extremo sacrificio das decisões participativas e uma incapacidade de consideração dos interesses heterogêneos da população. Destarte, as ambições de racionalidade social dos teóricos da revolução francesa pareceram definitivamente fracassadas, assim como todas as alternativas à arbitrariedade e ao despotismo na escolha social.

As questões cruciais da teoria da escolha social são deveras muito dificeis de responder, porque o que as motiva é a pretensão de alcançar consistência decisória em uma comunidade heterogênea de pessoas, com todas as idiossincrasias que lhes são peculiares (a despeito das tentativas de homogeneização amiúde empreendidas pelos poderes que as querem sujeitar). Por exemplo: como avaliar o progresso geral de uma sociedade sem desconsiderar os interesses divergentes dos seus membros? Como acomodar os direitos e as liberdades das pessoas enquanto simultaneamente conferindo adequado reconhecimento das suas preferências? E, 
sobretudo, dada a urgência suscitada pela nossa gravíssima crise ecológica, como aquilatar valorações sociais de bens públicos, tais como o meio-ambiente, perante o interesse de desenvolvimento econômico (de que atualmente sequer aproveita a maioria)?

Os resultados desanimadores de Arrow obrigaram os teoristas das decisões de grupo a indagarem o que os tornava aparentemente inevitáveis. A sua conclusão mais notável foi a de que alguns impasses poderiam ser resolvidos através de um aumento do conteúdo informativo dos procedimentos decisórios sociais. "Informações sobre comparações interpessoais de bem-estar e vantagens relativas revelaram-se particularmente cruciais nesta resolução" (SEN, 2009a, p. 93). Sen dedicou grande parte de sua carreira justamente à missão de conceber índices sociais e outros mecanismos capazes de ampliar o conteúdo informativo dos procedimentos de decisão coletiva.

Sen reconhece que a aparente distância da teoria formal da escolha social de questões de interesse imediato fez com que se tendesse a considerá-la extremamente limitada quanto à sua aplicabilidade para a razão prática e a argumentação pública. Mas, ao contrário do que pensam muitos comentadores, para Sen, a análise filosófica da justiça social, tal como promovida por Rawls na afamada $A$ Theory of Justice, não tem maior relevância prática do que a teoria da escolha social.

"Como uma disciplina avaliativa, a teoria da escolha social está

profundamente preocupada com a base racional de julgamentos sociais e decisões públicas na escolha entre alternativas sociais. Os resultados do procedimento de escolha social assumem a forma de uma classificação de diferentes estados de coisas desde um 'ponto de vista social', à luz das avaliações das pessoas envolvidas. Isto é muito diferente de uma busca da alternativa suprema entre todas as possíveis alternativas, com a qual teorias da justiça de Hobbes a Rawls e Nozick estão preocupadas." (SEN, 2009a, p. 95-96) ${ }^{7}$

Com efeito, a supramencionada ênfase na "base racional de julgamentos sociais e decisões públicas na escolha entre alternativas sociais" define precisamente o ponto em que a contribuição de Smith para a elaboração da teoria da escolha social foi mais proeminente. Sen propõe que o reconhecimento da "inescapável pluralidade de princípios concorrentes" é um dos 
pontos em que a teoria da escolha social mais explicitamente contribuiu para as reflexões sobre o tema da justiça. Principalmente a este respeito, a argumentação criativa de Smith, nomeadamente a sua elaboração da figura retórica do "espectador imparcial" oferece um subsídio inestimável.

De fato, Sen indica que a teoria da escolha social recomendou um considerável reconhecimento de uma pluralidade de razões, frequentemente conflitantes, passíveis de serem propostas por interlocutores razoáveis no debate sobre a justiça. Posto que inescapável, a concorrência de uma pluralidade de princípios nem sempre conduz ao impasse, mas essa passibilidade de conflitos duradouros entre crenças supostamente intransigíveis, segundo Sen, pode ser extremamente relevante para a teoria da justiça. (SEN, 2009a, p. 106).

Ademais, a contribuição de Smith também foi crucial para o estabelecimento de outro importante elemento da teoria da escolha social, qual seja a consideração de uma diversidade de interpretações e opiniões. Sen destaca o interesse considerável da teoria da escolha social pela distinção entre a agregação de interesses individuais e a agregação de juízos individuais: a voz de uma pessoa não conta apenas porque os seus interesses estão envolvidos, mas porque o seu raciocínio e juízo podem iluminar uma discussão; da mesma forma, o juízo de alguém pode ser levado em conta não só por essa pessoa ser uma das partes diretamente envolvidas, mas porque a sua perspectiva e as razões oferecidas para justificá-las fornecem importantes ideias e discernimento para a avaliação, havendo, pois, segundo Sen, motivos suficientes para ouvirem-se as suas razões, mesmo que essa pessoa não seja uma parte envolvida.

$\mathrm{Na}$ abordagem de Adam Smith, confere-se extraordinária importância à invocação de "espectadores imparciais" (mesmo que se trate de uma audiência de vozes distantes) pelas contribuições que podem trazer, com suas ideias, e para se evitar o paroquialismo de perspectivas exclusivamente locais. (SEN, 2009a, p. 108-109).

\section{V}

Qualquer teoria moral e política que privilegiasse certas pessoas em detrimento de outras (como era comum em enfoques tradicionais), e 
presumisse que apenas os membros de uma pequena casta fossem dignos de serem reputados objetos de consideração e respeito, dificilmente seria oficialmente aceita nos estados democráticos modernos, dado o atual estágio do desenvolvimento moral das sociedades que os constituem: o reconhecimento da universalidade dos direitos humanos é amiúde endossado como regra constitucional.

Sen observa que, mesmo se, de fato, concentramo-nos nas liberdades de um grupo particular de pessoas (como, por exemplo, os membros de uma nação, de uma comunidade ou de uma família), é preciso situar essa atenção em uma estrutura mais ampla e visar a alargar cada vez mais estes limites. A inclusão seletiva e arbitrária de uma categoria privilegiada (a única cujos interesses importam e cujas vozes são ouvidas) seria uma expressão de preconceito, viés e parcialidade. A universalidade da inclusão social (pelo menos in abstrato), e, por conseguinte, a imparcialidade, constitui uma das exigências fundamentais da justiça.

Para a satisfação dessa exigência, é necessário o estímulo do raciocínio público aberto, que por sua vez se retroalimenta da imparcialidade das posições propostas e dos argumentos apresentados para justificá-las. O filósofo e economista indiano defende que a imparcialidade na avaliação da justiça e dos arranjos sociais ocupa uma posição fundamental. No entanto, ele discerne uma diferença básica entre duas maneiras de se a invocar, e as denomina, respectivamente, imparcialidade aberta e fechada. (SEN, 2009a, p. 124-152).

No caso da imparcialidade fechada, o procedimento pelo qual são elaborados os juízos imparciais invoca apenas os membros de dada sociedade ou nação (aos quais Rawls denominava povo) para quem tais juízos são elaborados. O método rawlsiano da "justiça como equidade" recorre ao artificio da posição original e do contrato social concebido em seu domínio, cujos contratantes são os cidadãos dessa comunidade política originária. O procedimento político contratualista não conta necessariamente com a participação de nenhum estranho. No caso da imparcialidade aberta, em contrapartida, o procedimento pelo qual as avaliações imparciais são elaboradas também invoca juízos de fora do grupo focal, de modo a evitar o viés paroquial. Sen explica que, no cerne da concepção smithiana de imparcialidade está a necessidade do recurso aos juízos desinteressados de "qualquer espectador justo e imparcial". Perspectivas imparciais podem e 
devem, portanto, proceder de fora (mesmo que de longe), bem como de dentro de uma comunidade, nação ou cultura. (SEN, 2009a, p. 123).

$O$ artificio do espectador imparcial consiste em um experimento mental sobre a imparcialidade, e difere substancialmente da imparcialidade fechada rawlsiana, que é distintiva da sua concepção de justiça como equidade. A ideia básica é apresentada por Smith na Teoria dos sentimentos morais como a exigência, ao julgarmos a nossa própria conduta, de "examiná-la como imaginamos que qualquer outro espectador justo e imparcial a examinaria”. (SMITH, 1976, p. 110)

A necessidade de se considerar o modo como estados de coisas são percebidos por "qualquer espectador justo e imparcial” é uma exigência que pode incluir juízos realizados por pessoas desinteressadas de outras sociedades. Em contraste, o caráter institucionalmente construtivo de sistemas como o rawlsiano, na opinião de Sen, restringe a extensão na qual as perspectivas dos "outsiders" podem ser acomodadas dentro do exercício de avaliação imparcial. Ele explica que, embora Adam Smith frequentemente refira-se ao espectador imparcial como "o homem dentro do peito", um dos principais motivos da sua estratégia intelectual era "ampliar nossa compreensão e alargar o alcance de nossa investigação ética". (SEN, 2009a, p. 125). Nas palavras de Smith,

$\mathrm{Na}$ solidão, estamos aptos a sentir muito fortemente o que diz respeito a nós mesmos... A conversa de um amigo melhora o nosso temperamento, a de um estranho mais ainda. O homem dentro do peito, o espectador abstrato e ideal de nossos sentimentos e conduta, precisa muitas vezes ser despertado e conscientizado do seu dever pela presença do espectador real: e é sempre com esse espectador, de quem podemos esperar o mínimo de simpatia e indulgência, que provavelmente aprenderemos a lição mais completa de autodomínio. (SMITH, 1976, p. 153-154).

Smith invocara, portanto, o dispositivo reflexivo do espectador imparcial para transcender um raciocínio passível de ser imperceptivelmente constrangido por convenções locais de pensamento, e para examinar deliberadamente tais convenções como que desde a perspectiva de um "espectador" distanciado, como sugere Sen (2009a, p. 125). A justificação de Smith para tal procedimento de imparcialidade aberta é assim enunciada: 
Nunca podemos examinar nossos próprios sentimentos e motivações, nunca podemos formar qualquer juízo a respeito deles; a menos que nos retiremos, por assim dizer, de nossa própria posição natural, e nos esforcemos por vê-los como a certa distância de nós. Mas não podemos fazer isso de nenhuma outra maneira senão esforçando-nos por vê-los com os olhos de outras pessoas, ou como outras pessoas provavelmente os veriam. (SMITH, 1976, p. 110)

O raciocínio de Smith, portanto, não só admitiria, mas exigiria a consideração de multíplices opiniões. A relevância deste ponto para as questões que concernem à teoria da escolha social são inequívocas o bastante para precisarem ser ressaltadas.

Evidentemente, a questão mais relevante acerca do abandono dos interesses e perspectivas dos que não são partes no contrato social de uma comunidade política é o fato de sofrerem as consequências das decisões tomadas nessa comunidade política. Em um mundo em que as interações entre os vários povos e nações são, não apenas inevitáveis, mas cada vez mais iníquas, estabelecendo interdependências totalmente inconsistentes, em uma dialética entre nações senhoriais e povos servis, o problema da injustiça global deve ser a prioridade absoluta na agenda da justiça social. Há, aliás, o tenebroso agravante de uma situação por si só suficientemente trágica, qual seja o fato de já não se haver de falar apenas em nações ou estados senhoriais, mas em estados fantoches de corporações transnacionais. Ademais, hoje há povos que sequer podem ser considerados servis, pois que simplesmente já não servem a absolutamente nenhum interesse das autoridades constituídas pela soberania do capital, servindo apenas de um estorvo que, em não se o alimentando, o tempo se encarrega de eliminar.

Dada a conjuntura do mundo globalizado no limiar deste século tão próximo no tempo, mas tão distante na natureza - daquele mundo esperançoso dos tempos do "milagre econômico" que sucedeu a tragédia da Segunda Grande Guerra, o tema da justiça global está de tal maneira intrincado ao da justiça social que já não se os pode dissociar sem prejuízo da justiça, em sentido amplo. Pode-se mesmo afirmar que a justiça hoje ou é global ou não é justiça. Sen, por seu turno, acredita que a imparcialidade aberta, através do dispositivo smithiano do espectador imparcial, em cujo cerne se vislumbra o "não paroquialismo como 
requisito da justiça" (cf. SEN, 2009a, p. 403-408), tem muitos insights a oferecer a este assunto tão espinhoso.

Mas, essa questão excede o propósito deste artigo, que foi o de apenas apresentar brevemente, à guisa de introdução, um panorama da influência da obra de Adam Smith sobre o pensamento de Amartya Sen, especialmente sobre a sua formulação da teoria da escolha social. O tema, amplo e profundo, obviamente esteve longe de ser esgotado.

Tendo dedicado a sua carreira acadêmica à contestação das teses prevalecentes no pensamento econômico contemporâneo, nomeadamente as defendidas pelos teoristas da escolha racional, Sen demonstrou as suas limitações através de sua revisão da obra de Smith, cuja equivocada interpretação lhes servira de alicerce. O prevalecente ceticismo dos economistas em relação a questões envolvendo valores e elementos normativos, conforme demonstrado por Sen, não encontra qualquer respaldo na obra smithiana.

Com efeito, a doutrina econômica de Smith pressupõe e é indissociável da sua doutrina moral e política. O comportamento humano é complexo, e não se restringe ao egoísmo. Se, de fato, todos (e não apenas alguns agentes) fossem exclusivamente maximizadores do autointeresse, como quer a teoria da escolha racional, a sociedade simplesmente não subsistiria. Smith demonstrou, entretanto, que os seres humanos são dotados de uma pletora de sentimentos, e, sobretudo, da notável capacidade de participarem dos sentimentos uns dos outros, em que consiste a sympathy. Foi sobre essa compreensão da natureza psicológica do homem que Smith construiu a sua doutrina moral, centrada na imagem de um "espectador imparcial" que serviria como uma espécie de dispositivo ou método para a realização de avaliações morais. Estas levariam em conta não apenas a perspectiva e os interesses do agente, mas de todos os envolvidos.

Sen, como vimos, recorre a estas ideias na formulação da sua teoria da escolha social (em que essencialmente consiste a sua abordagem da justiça).

${ }^{1}$ Citando profusamente a Riqueza das Nações, Sen explica, por exemplo, como Smith previra o surgimento da atual crise bancária através da sua advertência em relação aos que promovem a assunção de riscos excessivos, os quais denominou "pródigos e projetores". Segundo Sen, Smith ficaria chocado com o fato de que a fé implícita na capacidade da economia de 
mercado corrigir-se a si mesma, que é a grande responsável pela eliminação das regulamentações dos mercados, ignorou as atividades perniciosas dos especuladores (cf. SEN, 2009c).

${ }^{2}$ Sen cita como exemplo o seguinte argumento de Smith: "Quando o povo de qualquer país tem tanta confiança na fortuna, na probidade e na prudência de um determinado banqueiro, ao ponto de acreditar que ele sempre estará disposto a pagar, quando requisitado, pelas notas promissórias passíveis de lhe serem apresentadas a qualquer momento; essas notas passam a ter a mesma aceitação que moedas de ouro e prata, pela confiança de que a qualquer momento essas moedas poderão ser possuídas por eles.” (SMITH, 1979, I, II.ii.28, p. 292).

${ }^{3}$ Sen explica assim a atual crise de confiança nos mercados: "There were, in fact, very good reasons for mistrust and the breakdown of assurance that contributed to the crisis today. The obligations and responsibilities associated with transactions have in recent years become much harder to trace thanks to the rapid development of secondary markets involving derivatives and other financial instruments. This occurred at a time when the plentiful availability of credit, partly driven by the huge trading surpluses of some economies, most prominently China, magnified the scale of brash operations. A subprime lender who misled a borrower into taking unwise risks could pass off the financial instruments to other parties remote from the original transaction. The need for supervision and regulation has become much stronger over recent years. And yet the supervisory role of the government in the US in particular has been, over the same period, sharply curtailed, fed by an increasing belief in the self-regulatory nature of the market economy. Precisely as the need for state surveillance has grown, the provision of the needed supervision has shrunk." (SEN, 2009c).

${ }^{4}$ De fato, a releitura da obra de Smith fora suscitada no contexto da sua investigação sobre a pobreza e a fome, que começara a ser empreendida nos anos 1970, e resultara na obra paradigmática de 1981, Poverty and famines. Nela, Sen evidencia a preocupação de Smith com o tema da desigualdade, recorrendo à sua ideia de privação relativa ao discorrer sobre a importância de se reconhecer a complexidade do conceito de pobreza e sua relação com os estilos de vida e padrões de consumo de determinada sociedade. A noção de pobreza não concerne apenas à subsistência, mas à satisfação das necessidades de bens e serviços que determinada sociedade considera indispensável a uma existência digna. Sen demonstra, portanto, que a ideia de exclusão social, associada à de privação relativa, tem sua origem em Smith. Sen já fornecia, assim, indícios suficientes de que a sua interpretação de Smith divergiria bastante das então prevalecentes.

${ }^{5}$ Recentemente, na esteira de Sen, vários autores têm revisado a obra de Smith e analisado a relevância e a influência dos aspectos morais sobre os aspectos econômicos do seu pensamento. Dentre estes se destacam Samuel Fleischacker (1999, 2004a, 2004b, 2010) e Emma Rothschild (2001).

${ }^{6}$ Vários autores, contudo, criticaram os fundamentos da teoria da escolha social, dentre eles mais duramente Jon Elster e Brian Barry (cf. SEN, 1986a, p. 213).

${ }^{7}$ Sen repetirá insistentemente nessa obra que as abordagens baseadas na ideia da situação transcendental de um contrato social originário são incapazes de enfrentar questões sobre o avanço da justiça e de comparar propostas alternativas em proveito de uma sociedade mais justa que não se baseiem em uma proposta utópica de dar um salto imaginário para um mundo perfeitamente justo. Segundo ele, as respostas que a chamada "abordagem transcendental" da

doispontos, Curitiba, São Carlos, vol. 10, n. 1, p.103-126, abril, 2013 
justiça oferece, ou pode oferecer, são "muito distantes do tipo de preocupações que suscitam o envolvimento das pessoas em discussões sobre justiça e injustiça no mundo (por exemplo, as iniquidades da fome, da pobreza, do analfabetismo, da tortura, do racismo, da sujeição feminina, do encarceramento arbitrário ou da exclusão médica como características sociais que precisam ser remediadas." (SEN, 2009a, p. 96). Não cabe aqui, lamentavelmente, avaliar a argumentação de Sen, central em The idea of justice, segundo a qual há duas linhas básicas e divergentes de raciocínio sobre a justiça que derivam do Iluminismo europeu: uma que ele denomina transcendental institutionalism, representada por autores como Hobbes, Locke, Rousseau, Kant, Rawls e Nozick, e outra chamada de realization-focused comparison, na qual se inscreve a teoria da escolha social no prolongamento de autores como Smith, Condorcet, Bentham, Marx e Mill. Para uma avaliação crítica, vide o ensaio de Pablo da Silveira (2012) e a mais recente obra de Ronald Dworkin (2011).

\section{Referências bibliográficas}

DWORKIN, R. 2011. Justice for hedgehogs. Cambridge, MA: Harvard University Press.

FLEISCHACKER, S. 1999. A third concept of liberty: judgment and freedom in Kant and Adam Smith. Princeton: Princeton University Press.

. 2004a. A short history of distributive justice. Cambridge, MA:

Harvard University Press. [FLEISCHACKER, S. 2006. Uma breve história da justiça distributiva. São Paulo: Martins Fontes].

. 2004b. On Adam Smith's Wealth of nations: a philosophical companion. Princeton, NJ: Princeton University Press.

FLEISCHACKER, S.; BROWN,V. (eds.). 2010. The philosophy of Adam Smith: essays commemorating the 250th anniversary of the theory of moral sentiments. New York: Routledge.

HAAKONSSEN, K. 2002. Introduction. In: SMITH, A. The theory of moral sentiments, edited by Knud Hakonssen. Cambridge: Cambridge University Press, p. vii-xxiv.

MORRIS, C.W. (ed.). 2010. Amartya Sen. Cambridge: Cambridge University Press.

NOBEL. 1998. Advanced information. Disponível em: <http:// www.nobelprize.org/nobel_prizes/economics/laureates/1998/ 
advanced-economicsciences1998.pdf>. Acesso em 10 nov. 2012.

RAWLS, J. 1999. A theory of justice: revised edition [1971]. Cambridge, MA: Harvard University Press. [RAWLS, J. 2008. Uma teoria da justiça. 3. ed., São Paulo: Martins Fontes].

ROTHSCHILD, E. 2001. Economic sentiments:Adam Smith, Condorcet, and the Enlightenment. Cambridge, MA: Harvard University Press. [ROTHSCHILD, E. 2003. Sentimentos econômicos: Adam Smith, Condorcet e o Iluminismo. Rio de Janeiro: Record].

ROTHSCHILD, E.; SEN, A. 2006. Adam Smith's Economics. In: HAAKONSSEN, K. (ed.). The Cambridge Companion to Adam Smith. Cambridge: Cambridge University Press, p. 319-365.

SEN, A. 1970. Collective choice and social welfare. San Francisco: Holden-Day. .1986a. Foundations of social choice theory: an epilogue. In: ELSTER, J.; HYLLAND, A. (eds.). Foudations of social choice theory. Cambridge: Cambridge University Press, p. 213-248. . 1986b. Adam Smith's prudence. In: LALL, S.; STEWART, F. (eds.). Theory and Reality in Development. London: Macmillan, p. 28-37. .1987. On ethics and economics. Oxford: Blackwell. 2000. Development as freedom. New York: Anchor Books. . 2009a. The idea of justice. Cambridge, MA: Harvard University Press.

2009b. Introduction. In: SMITH, A. The theory of moral sentiments [1759], edited by R.P. Hanley. New York: Penguin, p. vii-xxvi. .2009c. Adam Smith's market never stood alone. Financial Times, 10/03/2009. Disponível em: <http://www.ft.com/intl/cms/ s/0/8f2829fa-0daf-11de-8ea3-0000779fd2ac.html\#axzz2Cnii4j00>. Acesso em 11 mar. 2009. .2009d. Capitalism beyond the crisis. The New York Review of Books, 25/02/2009. Disponível em: <http://www.nybooks.com/ 
articles/archives/2009/mar/26/capitalism-beyond-the-crisis/>. Acesso em 26 fev. 2009.

.2010a. Adam Smith and the contemporary world. Erasmus Journal for Philosophy and Economics, v. 3, n. 1, p. 50-67, Spring 2010. . 2010b. The economist manifesto. New Statesman, 23/04/2010. Disponível em: <http://www.newstatesman.com/ideas/2010/04/ smith-market-essay-sentiments>. Acesso em 24 abr. 2010.

SMITH, A. 1976. The theory of moral sentiments [1759, 1790], edited by D.D. Raphael and A.L. Macfie. Oxford: Clarendon Press.

.1979. An inquiry into the nature and causes of the wealth of nations [1776, 1789], edited by R.H. Campbell and A.S. Skinner. Oxford: Clarendon Press.

SILVEIRA, P. da. 2012. ¿Cuál es el lugar de la razón en la búsqueda de la justicia? Amartya Sen y la distinción entre enfoques trascendentales y comparativos. In: BAVARESCO, A. et. al. (Orgs.). Justiça, Democracia e Política. Porto Alegre: EDIPUCRS, pp. 63-97. 


\title{
Os conceitos de justo e injusto em Aristóteles: entre EN V,1 e EN V,9
}

\author{
Mateus de Campos Baldin \\ mateus.baldin@gmail.com \\ Universidade Federal do Rio Grande do Sul (UFRGS), Porto Alegre, Brasil
}

resumo Alguns autores de Filosofia do Direito, em especial Michel Villey, tentaram apresentar o que pensavam ser a teoria aristotélica da justiça, fundamentando a partir dela suas próprias teorias. Para Villey, em específico, “o direito" seria a correta tradução do grego to dikaion. Defender com base em Aristóteles uma concepção de justo que recuse elementos subjetivos de uma teoria da ação é um erro. E esse erro parece estar em ignorar uma redefinição de to dikaion feita por Aristóteles no Capítulo 9 do Livro V da Ética Nicomaqueia. Ali, Aristóteles acrescenta às condições objetivas do justo e do injusto (EN V, 1-7) algumas condições subjetivas referentes àquele que sofre a ação. Somente após entendermos essas condições seremos capazes de entender corretamente a teoria aristotélica da justiça. Como Villey e outros autores as ignoram, eles erram ao interpretar Aristóteles e utilizá-lo para fundamentar suas próprias ideias.

palavras-chave Aristóteles; Michel Villey; Justiça; Ética Nicomaqueia

\section{Introdução}

Após o colapso do voluntarismo jurídico do século XIX, surgiu no direito, e em especial no direito privado, uma nova tendência (que de modo algum pode ser considerada uma escola ou movimento unificado) que procura analisar a justiça da relação intersubjetiva mediada pelo direito de uma forma objetiva, com uma minimização do uso de certos conceitos antes juridicamente essenciais como os de ação voluntária, vontade e escolha. $\mathrm{Na}$ esteira dessa tendência tornou-se possível o renascimento 
de institutos de direito romano e medieval dentro dos sistemas jurídicos contemporâneos. Institutos como a lesão, o enriquecimento sem causa e a responsabilidade civil objetiva, bem como cláusulas como a boa-fé objetiva, a função social e mesmo a culpa objetiva, já se tornaram comuns em nossas leis e decisões judiciais.

Para dar conta desses novos institutos que vieram a fazer parte de nossos sistemas de direito positivo, o velho modo voluntarista de encarar o direito não mais servia. Autores de diversas correntes procuraram por diferentes fundamentos para essa nova tendência objetivizante no direito. Enquanto alguns autores recorreram a escolas neohegelianas e neokantianas, outros recorreram a autores mais antigos, como a Aristóteles e Tomás de Aquino.

Alguns desses autores apelaram para a ideia de equidade, como por exemplo, o próprio Clóvis Bevilacqua, autor do Código Civil Brasileiro de 1916 (BEVILAQUA, 1903). Outros autores se valeram em grande medida de uma retomada de uma visão mais geral da exposição aristotélica da justiça e, em especial, do conceito aristotélico de justo (to dikaion), i.e., o adjetivo neutro apresentado como sendo o objeto da justiça, e não justo no sentido de pessoa justa (ho dikaios). Trata-se do justo enquanto qualificação de estados de coisas, e não de pessoas.

Entre esses últimos, tem especial relevância o nome de Michel Villey (VILLEY, 1977 e VILLEY, 2003, pp. 54-96), no direito em geral, e de Ernst Weinrib (WEINRIB, 1995) e James Gordley (GORDLEY, 2006) no direito privado. $\mathrm{O}$ que esses autores tão diferentes entre si quanto a objetivos e métodos têm em comum é sua visão de que a totalidade do direito (no caso deVilley) ou ao menos a totalidade do direito privado (no caso de Weinrib e Gordley) somente pode ser corretamente compreendida se recorrermos ao conceito aristotélico de justo e, mais especificamente, ao justo enquanto objeto da justiça particular. Para Villey, "O Dikaion só é concebido em seu sentido rigoroso no interior da justiça particular" (VILLEY, 2003, p. 74).

Uma característica comum desses autores é uma apresentação da teoria da justiça aristotélica que a isola da visão aristotélica mais geral sobre a ética e sobre a ação humana. Assim, pretendem eles, a teoria aristotélica da justiça pode ser compreendida sem se recorrer a sua teoria da ação e, por isso mesmo, sem se recorrer aos conceitos de ação voluntária e escolha. Essa característica, porém, não é exclusiva desses autores, podendo também ser 
encontrada em outros cuja preocupação central é a Ética e não a Filosofia do Direito. Também aqui a teoria aristotélica da justiça é por vezes apresentada sem maiores preocupações em ligá-la a uma teoria da ação moral (ver, e.g., BOSTOCK, 2000, pp. 54-73 e MILLER JR., 1995, pp. 67-86).

Essa forma de exposição da teoria aristotélica está talvez ligada à preocupação inicial de fundar o direito em uma visão puramente objetiva da justiça, entendendo-se por objetivo uma visão que não necessite recorrer a qualquer caracterização da ação humana ou dos agentes para que se fale de um estado de coisas como sendo justo ou injusto. É esse estado de coisas justo, e não as regras sociais ou o modo de ação humana sob essas regras, que seria o próprio direito.Villey, em especial, é claro em suas colocações, inclusive rejeitando a tradução tradicional de to dikaion por "o justo" e adotando a tradução "o direito":

Mas, o "direito", no sentido maior do termo, não designa a profissão ou a atividade dos juristas; mostra-se como uma coisa que o jurista busca, estuda, em torno da qual parece gravitar o ofício do jurista. A contribuição mais original da doutrina do direito de Aristóteles é precisamente a análise do termo justiça e, contudo, distinto desta: to dikaion - cuja melhor tradução em língua francesa é "o direito", e que os romanos da época clássica traduziam por jus. No livro V da Ética o direito (to dikaion) mais do que a justiça (dikaiosunê) constitui o tema principal. (VILLEY, 2003, p. 69) ${ }^{1}$.

O objetivo dessa exposição é demonstrar como estas interpretações objetivizantes do conceito aristotélico de justo são incompletas e, portanto, equivocadas. A tese que aqui defenderei é a de que interpretações do justo como sendo "a coisa justa" em sentido inteiramente objetivo, i.e., sem referência à ação voluntária, deixam de lado o grande papel que Aristóteles dá à voluntariedade na relação intersubjetiva de justiça, um papel decisivo para se poder julgar corretamente ações, situações e estados de coisas como justos ou injustos. Assim, dentro do próprio conceito de justo, através da análise da injustiça (hê adikia), parece estar incluída uma condição voluntarista, por assim dizer. Ou seja, uma condição que faz referência a conceitos como ação voluntária.

Isso que considero como insuficiência na interpretação do conceito aristotélico de justo está, creio, na leitura incompleta do Livro V da Ética 
Nicomaquéia. Acredito que essa insuficiência possa ser explicada pelo fato de que autores como Villey, Weinrib e Gordley preocupam-se exclusivamente com a definição aristotélica do justo contida no Capítulo 1 do Livro $V$ da EN, ignorando uma espécie de redefinição ou aprimoramento da definição feita por Aristóteles no Capítulo 9 do mesmo livro.

Uma outra conclusão, embora indireta, de minha exposição, será a de que um mesmo conceito de justo aparece tanto em suas instanciações ligadas à justiça particular quanto nas ligadas à justiça geral. Desse modo, se minha exposição estiver correta, devemos rejeitar também a tese de Villey de que o "sentido rigoroso" de to dikaion se dá apenas "no interior da justiça particular" (VILLEY, 2003, p. 74).

Defenderei que as diferenças entre essas duas definições de to dikaion, i.e., a do Capítulo 1 e a do Capítulo 9 (e não as diferenças entre o to dikaion da justiça geral e o da justiça particular) ${ }^{2}$ são cruciais para se entender por que as teses errôneas acima mencionadas, i.e., as de que a) o direito é apenas o estado de coisas justo e b) a correta compreensão dos institutos jurídicos não necessita fazer uso de conceitos pertencentes a uma teoria da ação voluntária, não decorrem da teoria aristotélica da justiça. Quais são, então, as diferenças entre as definições de justo no Capítulo 1 e no Capítulo 9?

\section{As definições do justo e do injusto em EN V,1}

Aristóteles inicia o Livro V da Ética Nicomaquéia com a observação de que a investigação da justiça (hê dikaiosunê) deve seguir o mesmo procedimento da investigação anteriormente feita acerca das demais virtudes, e este procedimento é a análise das opiniões reputadas (ENV,1 1129 a 5-6).

Vemos que todos querem dizer por justiça aquela disposição moral do justo, e que leva à ação justa e a desejar o que é justo; e de modo similar em relação à injustiça [todos querem dizer] aquela disposição que leva à ação injusta a desejar o que é injusto. E nós vamos assumir, para iniciar, que essa definição esteja em larga medida correta. (ENV,1 1129 a 7-11) ${ }^{3}$.

Assim, Aristóteles busca uma definição inicial de justiça com a qual poderemos trabalhar na análise que se segue: chamamos de justiça a disposição 
moral pela qual os homens se tornam aptos a fazer o que é justo, a agir justamente e a desejar o que é justo. E, de modo oposto, temos uma definição inicial de injustiça: chamamos de injustiça ao que leva os homens a agir injustamente e a desejar o que é injusto.

Deste modo, é central para Aristóteles a definição do justo e do injusto enquanto qualificadores de ações e estados de coisas para que seja feito um estudo do que é a justiça. Isso porque, em sua definição inicial de justiça já estão presentes os conceitos de justo e injusto. E isso implica que devemos antes comprendê-los para depois podermos compreender a disposição moral da justiça. E é exatamente isso o que faz Aristóteles na sequência do texto, logo após algumas observações sobre a homonímia dos termos tratados.

Justiça e injustiça são termos usados em diferentes sentidos, mas que em geral passam despercebidos, por estarem conectados (EN V, 11129 a 23-31). Esses sentidos são dados pela análise dos conceitos de injusto e de justo. E esses têm seus sentidos revelados pela análise dos conceitos de homem injusto (ho adikos) e de homem justo (ho dikaios).

Vamos, então, encontrar em quais sentidos se chama um homem injusto.

[O termo homem injusto] é tido como se aplicando tanto àquele que viola a lei quanto àquele que deseja mais do que o que lhe cabe, assim está claro que homem justo será tanto aquele que segue a lei quanto aquele que busca o igual. (ENV,1 1129 a 31-34) ${ }^{4}$.

Então, injusto será tanto o homem que viola a convenção ou lei da comunidade, quanto o homem que toma para si mais do que lhe cabe. E, por oposição, será justo tanto o homem que age de acordo com a convenção ou lei da comunidade, quanto o homem que toma para si exatamente aquilo que lhe cabe.

Aristóteles faz ainda duas distinções numa passagem posterior. A primeira é a distinção entre a ação injusta e o injusto, enquanto a segunda é a distinção entre ação justa e o justo. A ação justa é aquela que tem por objeto o justo, enquanto a ação injusta é aquela que tem por objeto o injusto (EN V, 71135 a 9-10).

Por sua vez, espelhando a distinção acima feita para o homem justo, pode-se distinguir dois sentidos para o justo e para o injusto: "Por um lado, o justo [é] o que está de acordo com a lei e o [que é] igual, por 
outro, o injusto [é] o que viola a lei e o [que é] desigual." (ENV,1 1129 a $34-35)^{5}$.

Então, em seu primeiro sentido o justo é definido como o que está de acordo com a lei ou convenção da comunidade política; ${ }^{6}$ enquanto em seu segundo sentido, é definido como o que é igual. O injusto é, por oposição, definido em seu primeiro sentido como o que é contrário à lei ou à convenção, e em seu segundo sentido como o que é desigual (ver KRAUT, 2002, p. 114, n. 25 e IRWIN, 1988, pp. 623-624).

E, desta distinção, segue-se aquela entre justiça geral e justiça particular. $^{7}$ A justiça geral é a justiça concebida como a totalidade da virtude exercida em relação a outros, tendo em vista o bem comum, ou a felicidade ou aquilo que compõe a felicidade da comunidade política (ENV,1 1129 b 14-19, 1129 b 25-1130 a 1). A justiça é, neste sentido, o bem dos outros, porque busca vantagem para os outros e não para si mesmo (EN V,1 1130 a 3-4). A justiça geral não é uma virtude moral entre as demais, mas a totalidade das virtudes morais exercidas para com outros, e buscando a vantagem dos outros (o bem comum de uma comunidade), em conformidade com a convenção da comunidade (ENV,1 1130 a 8-13). O objeto da justiça geral é, então, o justo (to dikaion) no sentido daquilo que está de acordo com a convenção ou lei da comunidade política.

A justiça particular, por sua vez, é uma virtude moral específica que, ao lado das demais, é parte da virtude da justiça geral (ENV,2 1130 a 1416). Trata-se da virtude que diz respeito ao modo de se lidar com bens exteriores, i.e., bens dos quais é possível ter mais ou menos (ENV,1 1129 b 1-6). Trata-se da justiça que tem por objeto o justo no sentido daquilo que é igual, ou seja, uma igualdade no que se refere a bens exteriores. $\mathrm{E}$ essa igualdade se dará em distribuições (EN V, 3), correções (EN V, 4) e trocas (ENV, 5).

Justiça é, assim, um termo que se refere a duas virtudes morais distintas, mas relacionadas no sentido de que uma delas, a justiça particular, é parte da outra, a justiça geral. Ambas tem por objeto o justo, em um caso entendido como o igual, em outro como o legal. E ambas buscam evitar o injusto; em um caso o desigual, em outro o ilegal.

Ocorrerá uma injustiça geral quando uma ação ou estado de coisas estiver em contrariedade com as virtudes exercidas para com outros. Ocorrerá uma injustiça particular quando uma ação ou estado de coisas 
atribuir bens exteriores de modo desigual às partes envolvidas, de acordo com os critérios de igualdade nas possíveis situações de distribuição, correção e troca apresentadas em ENV, 3-5.

Como se percebe, nas definições do justo e do injusto dadas em ENV, 1 não há menção a conceitos como o de ação voluntária. Embora na definição de ação justa esse conceito esteja obviamente presente, é a ação justa que é definida a partir do justo, e não o oposto. O justo é, aqui, aquilo que é justo, ou seja, uma situação ou estado de coisas que podemos predicar como justo, quer por estar de acordo com a lei, quer por promover uma igualdade quanto aos bens exteriores.

Não há espaço para a voluntariedade. Com isto, quero dizer que não cabe, pelas definições aqui dadas, aos agentes ou àqueles que sofrem com ações alheias estabelecer, por meio de suas escolhas, o que é ou não justo. ${ }^{8}$ Dizendo de outro modo, suas escolhas não parecem, aqui, ser capazes de afetar a justiça ou injustiça de suas ações ou dos estados de coisas delas resultantes. Estes serão julgados apenas por sua concordância ou não com a lei ou convenção, ou pelo resultado igual ou desigual, pouco importando o que os que agem e os que sofrem com a ação pensem sobre isso.

Esta interpretação é, excetuando-se obviamente a terminologia, semelhante àquelas apresentadas porVilley e Weinrib em suas obras. E, como vimos, é o justo no sentido daquilo que é igual queVilley considera como sendo o direito (ius) (VILLEY, 1977 e VILLEY, 2003, pp. 54-96). Mas a exposição aristotélica sobre o justo objetivo não se esgota aqui. Mais adiante no Livro V da Ética Nicomaquéia, ele volta a tratar do justo, agora em sua conexão com a ação voluntária.

\section{Voluntariedade, justiça e injustiça}

A voluntariedade e a involuntariedade já haviam sido tratadas no Livro III da Ética. Porém, o tema é retomado em EN V, 8, que trata especificamente da voluntariedade e da involuntariedade dentro do âmbito da justiça e da injustiça.

Aristóteles diferencia ação justa de ação conforme a justiça, e ação injusta de ação conforme a injustiça. Uma ação é justa se for realizada voluntariamente visando o que é justo, tal como definido em EN V, 1. 


\section{4}

Uma ação é voluntária quando está sob o controle do agente, sendo realizada por este com conhecimento de quem é afetado, do instrumento empregado e do resultado, excluindo-se acidente e compulsão externa. Uma ação é injusta se realizada nas mesmas circunstâncias, mas visando o injusto (ENV, 81135 a 19-28).

Porém, uma ação voluntária pode ser realizada por escolha ou sem escolha. É realizada por escolha uma ação voluntária que ocorra após uma prévia deliberação. Na ausência dessa deliberação, a ação é voluntária, mas não é realizada por escolha (ENV, 81135 b 8-11).

Uma ação que prejudique alguém pode ser feita a) na ignorância das circunstâncias relevantes; ou b) no conhecimento das circunstâncias relevantes, mas sem escolha, ou seja, sem prévia deliberação; ou ainda c) no conhecimento das circunstâncias relevantes e com escolha. Uma ação que prejudique alguém realizada na ignorância das circunstâncias relevantes (o primeiro caso) caracteriza um erro. $\mathrm{O}$ erro pode ser um infortúnio (se o resultado da ação for contrário à expectativa razoável) ou um erro perdoável (se o resultado da ação não for contrário à expectativa razoável, mas tenha ocorrido sem intenção de prejudicar quem foi afetado com a ação). Nenhum desses tipos de erro é culpável. Não há aqui ação injusta, apesar de ter ocorrido algo que, pela definição de justo que acabamos de ver em EN V, 1, caracterizaria uma injustiça. Uma ação que prejudique outrem realizada no conhecimento das circunstâncias relevantes, porém sem escolha (o segundo caso) caracteriza uma ação conforme o que é objetivamente injusto. Mas não caracteriza uma ação injusta. Somente uma ação que prejudique outrem e tenha sido realizada no pleno conhecimento das circunstâncias relevantes e por escolha (o terceiro caso) caracteriza uma ação injusta (ENV, 81135 b 11-1136 a 5).

Após tratar algumas outras questões referentes ao justo que escapam ao objetivo desse trabalho, em EN V, 9, Aristóteles se pergunta se é possível para alguém sofrer voluntariamente uma injustiça. O filósofo inicia dizendo que ser tratado justa ou injustamente parece ser o oposto de agir justa ou injustamente:

Pois é realmente possível sofrer voluntariamente uma injustiça, ou,

pelo contrário, sofrer uma injustiça é sempre involuntário, assim como agir injustamente é sempre voluntário? E novamente, sofrer o injusto é sempre voluntário, ou sempre involuntário, ou ora um, ora outro? E 
similarmente com o ser tratado justamente (pois agir justamente [é] sempre voluntário). (ENV, 91136 a 15-22) 9 .

Se é assim, existem quatro possibilidades para uma ação em relação a outrem: a) agir voluntária e justamente, b) agir involuntária e justamente, c) agir voluntária e injustamente, e d) agir involuntária e injustamente. Como contraponto a esses quatro modos de agir, há quatro possibilidades quanto a ser tratado, i.e., quanto ao sujeito passivo da ação de outrem, como nos mostra o texto: a) ser tratado voluntariamente de modo injusto, b) ser tratado involuntariamente de modo justo, c) ser tratado voluntariamente de modo injusto, e d) ser tratado involuntariamente de modo injusto.

Deste modo, o ser tratado justa ou injustamente pode ser voluntário ou involuntário, do mesmo modo como agir justa ou injustamente o pode. Aristóteles ilustra esse ponto dizendo que nem sempre alguém é tratado de modo justo voluntariamente, "pois alguns são assim tratados contra sua vontade" ${ }^{10}$ (ENV, 91136 a 22-23). Um exemplo seria um criminoso que recebe a pena justa apesar de não querer ser preso por seus crimes.

A partir daqui, Aristóteles coloca a discussão em novos termos, trazendo para aquele que sofre a ação (o sujeito passivo da relação de justiça) algo que anteriormente já havia estabelecido para aquele que pratica a ação (o sujeito ativo):

A seguinte questão pode também ser levantada, se sempre aquele que sofre a ação injusta sofre o injusto, ou ocorre como no caso daquele que age, pois pode-se ser parte no justo tanto como agente quanto como paciente? (ENV, 91136 a 23-27) ${ }^{11}$.

Pode-se agir de acordo com o que é objetivamente justo sem se realizar uma ação justa e pode-se agir de acordo com o que é objetivamente injusto sem se realizar uma ação injusta, porque as ações justas e injustas implicam fazer aquilo que é justo ou injusto voluntariamente. ${ }^{12}$ No caso daquele que sofre com a ação (o sujeito passivo de uma relação de justiça), seria possível, então, dizer que alguém pode sofrer o que é objetivamente injusto sem ter sofrido injustamente, pois sofrer injustamente implica ter sofrido contra sua vontade? 


\section{A redefinição do injusto em EN V, 9}

Aristóteles é levado a redefinir a ação injusta para poder responder corretamente a essa pergunta defendendo a tese de que é impossível para alguém sofrer voluntariamente uma injustiça (IRWIN, 1999, p. 236). Vejamos como procede seu argumento.

Primeiramente Aristóteles nos lembra que agir injustamente não é o mesmo que agir conforme ao que é objetivamente injusto:

Do mesmo modo, é claro que o mesmo se dá quanto ao injusto: pois não é o mesmo fazer o injusto e agir injustamente, e [não é o mesmo] também sofrer o injusto e sofrer injustamente, e o mesmo também com agir justamente e ser tratado justamente; pois é impossível sofrer o injusto sem que [a outra parte] aja injustamente, e sofrer o justo sem que [a outra parte] aja justamente. (ENV, 91136 a 26-29) ${ }^{13}$.

A relação de justiça pressupõe um sujeito ativo e um sujeito passivo. Assim, é impossível para o sujeito passivo ser tratado injustamente sem que o sujeito ativo aja injustamente. Do mesmo modo, é impossível que o sujeito passivo seja tratado justamente sem que o sujeito ativo aja justamente.

Como vimos anteriormente, para uma ação ser injusta não basta que tenha sido realizada de acordo com o que é injusto, mas também que tenha sido realizada voluntariamente: com conhecimento de quem é afetado, do instrumento e da maneira com que é afetado.

Como Aristóteles quer defender a tese de que "é impossível sofrer voluntariamente uma injustiça, ele é levado, então, a redefinir ou complementar a definição anterior de justo (to dikaion).

Isso porque qualquer tentativa de afirmar que ninguém aceitaria ser tratado conforme o que é objetivamente injusto não pode ser aceita integralmente em virtude da teoria aristotélica da voluntariedade, que exclui a necessidade de escolha deliberada para que uma ação seja voluntária. Desse modo, pode ser o caso que um incontinente voluntariamente, embora não deliberadamente, aceite que lhe seja feito o que é conforme o objetivamente injusto (ENV, 91136 b 2-3).

Assim, dizer que ninguém aceitaria ser tratado de modo injusto não é uma boa resposta para o problema. Para defender a tese de que é impossível ser tratado voluntária e injustamente ao mesmo tempo, Aristóteles 
precisa de uma nova definição de injusto, que complemente a definição inicial que, como vimos, ele aceita provisoriamente em ENV,1.

Não basta uma ação voluntária realizada conforme a injustiça para que se caracterize o injusto; da mesma forma que não basta uma ação voluntária conforme a justiça para que haja o justo. ${ }^{14}$ Isso porque aquele que sofre a ação pode sofrê-la voluntariamente. Assim, para que ocorra o injusto objetivo, é preciso que aquele que sofre a ação a sofra involuntariamente, ou seja, é preciso que a ação injusta do sujeito ativo da relação de justiça tenha sido feita contra a vontade do sujeito passivo.

Aristóteles pergunta-se se não deveríamos fazer uma modificação na definição inicialmente aceita em ENV,1:

Ou talvez essa definição esteja incorreta e devamos acrescentar a "causar dano conhecendo quem [a pessoa afetada], com o que [o instrumento utilizado] e o modo", [a fórmula] "contra a vontade [dessa] pessoa". Se for assim, embora um homem possa sofrer e possa ter o que é [objetivamente] injusto feito a ele, não pode sofrer [o injusto] voluntariamente, porque ninguém pode querer sofrer, mesmo o incontinente, que age contrariamente a sua vontade; dado que ninguém deseja algo que não julga ser bom, e o incontinente faz o que não julga bom. (ENV, 91136 b 3-9) $)^{15}$.

Feita essa adição à definição original, podemos dizer que uma pessoa pode ser prejudicada voluntariamente e sofrer voluntariamente o que é injusto, mas ninguém pode dizer que sofreu voluntariamente uma injustiça, nem mesmo uma pessoa incontinente.

Se for assim, então também o justo e o injusto devem ser redefinidos, necessitando-se verificar não apenas as condições objetivas (i.e., aquelas mencionadas em EN V, 1-7), mas também verificar se aquele que sofre com a ação ou estado de coisas o faz voluntariamente ou não. Se sofre voluntariamente, teremos o injusto apenas em seu sentido original (algo que não é em si justo), mas não em seu sentido próprio (algo que não é em si justo e que se produz contra a vontade de quem o sofre).

Isto vale tanto para a injustiça geral como para a injustiça particular? O texto de ENV, 9 parece não fazer esta distinção, pois prejudicar outrem pode ser resultado de qualquer ação conforme um vício ou contra a convenção, o que caracterizaria um injusto no sentido da injustiça legal ou 
geral. Além do mais, dada sua própria definição, a justiça particular é parte da justiça geral e, por conseguinte, o justo particular é também justo geral (embora o inverso não seja necessariamente o caso). Se é assim, Aristóteles acaba, então, por redefinir o justo e o injusto tanto em sua acepção geral quanto em sua acepção particular. Assim, um estado de coisas completamente injusto só pode ocorrer quando aquele que sofre a ação injusta a sofre involuntariamente.

Não basta, para que se possa falar de um estado de coisas como injusto, que ele seja o que é contra a convenção, nem que seja o que é desigual, mas é necessário também que aquele que sofre o prejuízo o sofra contra sua vontade. Assim, por essa mesma definição, ainda que um estado de coisas acabe por ser contra a convenção ou desigual (por exemplo, dando a alguém aquilo que não lhe cabe), ele não será completamente injusto se aquele que é afetado pela ação que causou tal estado de coisas a tenha aceitado voluntariamente. Caso quem sofra com essa ação a aceite voluntariamente, o estado de coisas resultante deve ser qualificado como ao menos relativamente injusto, quando não relativamente justo.

Assim, dada essa redefinição, temos dois conjuntos de condições que uma ação ou estado de coisas deve satisfazer para podermos qualifica-los de justos: condições objetivas (apresentadas en EN V, 1-7) e condições subjetivas (apresentadas em ENV, 8-9). Então, o justo e o injusto admitem variação de grau: do completamente injusto (nem as condições objetivas nem as subjetivas do justo são satisfeitas) ao completamente justo (tanto as condições objetivas quanto as subjetivas são satisfeitas), passando por situações intermediárias (apenas as condições objetivas, mas não as subjetivas, são satisfeitas; ou o inverso).

\section{Conclusão}

A conclusão a que podemos chegar aqui é de que Aristóteles é mais voluntarista do que pode parecer a um primeiro momento, e certamente mais do que o modo como o aristotelismo é apresentado pelos filósofos do direito que, como Villey, Weinrib e Gordley, que procuram ver no to dikaion apenas e tão somente um estado de coisas que pode ser apreciado sem referência à voluntariedade ou não da ação daqueles nele envolvidos. 
Como esses autores, em especial Villey, ignoram os Capítulos 8 e 9 do Livro V da Ética Nicomaqueia, eles se fixam apenas nas condições objetivas do justo, deixando de lado as condições subjetivas. Somente assim Villey pode falar em "coisa justa" ou "direito" como traduções de dikaion.

Porém, este "voluntarismo" aristotélico é radicalmente distinto do voluntarismo que prevaleceu no pensamento jurídico no século XIX. A objetividade do justo e do injusto depende sim da ação dos agentes, ao contrário do que entendia Villey. Mas o justo e o injusto são apenas parcialmente dependentes da ação voluntária (ENV, 8-9), pois sua justiça está tanto no modo como o sujeito passivo recebeu a ação quanto nas condições objetivas de avaliação do estado de coisas resultante da ação (ENV, 1-7).

Meu objetivo aqui restringiu-se à exegese do texto do LivroV da Ética Nicomaquéia, especialmente seus capítulos 1 e 9, como forma de demonstrar a falsidade da visão de que o justo e o injusto podem ser definidos sem se preocupar com conceitos de uma teoria da ação, como o conceito de ação voluntária, por exemplo. E essa análise é suficiente para demonstrar que as interpretações objetivistas puras, como a deVilley, são insuficientes para dar conta da complexidade da teoria aristotélica da justiça. E, muito embora não tenha sido objeto desse estudo, essas teorias parecem também insuficientes para dar conta da complexidade do fenômeno jurídico.

Aristóteles se revela muito mais sutil que o objetivismo puro deVilley, Weinrib e Gordley. Mas também é muito mais sutil que o simples voluntarismo que vê na vontade a única fonte de obrigações jurídicas. Creio que, com isso, o objetivo modesto que tracei no início foi cumprido.

Para uma melhor reconstrução da teoria aristotélica da justiça, é necessário, é claro, analisar mais detalhadamente a ligação entre a definição inicial e esta definição final do justo e do injusto. Do mesmo modo, é necessário fazer um estudo mais aprofundado desse tema em sua relação com outros livros da Ética Nicomaquéia. Mas isso é um trabalho diferente daquele a que me propus levar a cabo aqui.

${ }^{1}$ ParaVilley, é central sua tradução de to dikaion por "a coisa justa" ou por "o direito", de modo a poder remeter a Aristóteles a defesa de sua tese de que o direito é a coisa justa e é separado da 
moralidade, que seria prescritiva. No caso da primeira dessas traduções, "coisa justa", podemos simplesmente abandonar por erro categorial (to dikaion não é uma coisa). No caso da segunda, ela somente poderia ser utilizada se a tese estivesse correta, o que, como veremos, não está. Assim, mantenho a terminologia tradicional, traduzindo to dikaion simplesmente por "o justo", uma substantivação de um adjetivo neutro.

${ }^{2}$ Villey acredita que é a diferença entre justiça geral e justiça particular que nos dá a diferença entre direito e moralidade. Enquanto o direito seria "a coisa justa" segundo os critérios da justiça particular (ENV,2), a moralidade seria o justo legal ou geral (ENV, 1). Mas, ao focar nas diferenças entre esses, Villey esquece que há homonímia entre dikaion usado como justo segunda a lei e dikaion usado como justo segundo um critério de igualdade. Assim, o que Aristóteles fala em ENV, 1 e mais tarde em ENV, 9 se aplica a ambos os casos, e não apenas a um deles. Trata-se de conceitos homônimos em que um é englobado pelo outro. Ao não perceber isso,Villey se sente tentado a fazer inserir ali uma diferença artificial entre moralidade e direito, esquecendo-se que o justo em seu sentido particular é considerado por Aristóteles como parte do justo em seu sentido geral. Sendo assim, o que Aristóteles afirma sobre o justo geral deve também se aplicar ao justo particular.

${ }^{3}$ Horômen dê pantas tên toiautên exin boulomenous legein dikaiosunên af' hês praktikoi tôn dikaiôn eisi, kai af'hês dikaiopragousi kai boulonta ta dikaia: ton auton de tropon kai peri adikias, af'hês adikousi kai boulontai ta adika. dio kai hêmin prôton hôs en tupôi Hupokeistô tauta. (ENV,1 1129 a 7-11). Exceto quando de outro modo indicado, as traduções foram feitas a partir do texto da Loeb Classical Library (ARISTÓTELES, 1934) com consultas à tradução de H. Rackham que o acompanha, bem como às traduções de Terence Irwin (ARISTÓTELES, 1999) e W. D. Ross (ARISTÓTELES, 1984).

4 eilêfthô dê ho adikos posachôs légetai. dokei dê ho te paranomos adikos einai kai ho pleonektês kai anisos, hôste dêlon hoti kai [ho] dikaios estai ho te nomimos kai ho isos. (ENV,1 1129 a 31-34).

5 to men dikaion ara to nomimon kai to ison, to d'adikon to paranomon kai to anison. (ENV, 11129 a 34-35).

${ }^{6}$ Aqui Aristóteles se refere não apenas à lei ou convenção tal como é (nomos), mas também àquilo que deveria ser lei, enquanto produto da atividade legislativa (ta nomima) corretamente exercida (ver KRAUT, 2002, p. 114, n. 25).

7 Deve-se enfatizar que a nomenclatura "justiça geral" e "justiça particular" não tem correspondência no texto aristotélico, sendo devida aos comentadores. Apesar disso, expressa bem a distinção feita por Aristóteles entre duas virtudes às quais se dá o nome de justiça (hê dikaiosunê).

${ }^{8}$ Exceto, é claro, indiretamente, quando participam da elaboração da lei.

${ }^{9}$ poteron gar hôs alêthôs estin ekonta adikaisthai, ê ou all'akousion hapan, hôsper kai to adikein pan hekousion: kai ara pan outôs ê ekeinôs [hôsper kai to adikein pan ekousion], ê to men hekousion to d'akousion: homoiôs de kai epi tou dikaiousthai (to gar dikaiopragein pan hekousion). (EN V, 91136 a 15-22).

doispontos, Curitiba, São Carlos, vol. 10, n. 1, p.127-142, abril, 2013 
10 enion gar dikaiountai ouch hekontes. (ENV, 91136 a 22-23). Utilizo aqui a tradução brasileira de Mário da Gama Kury (ARISTÓTELES, 2001).

11 epeita kai tode diaporêseien an tis, poteron ho to adikon peponthôis, adikeitai pas ê estin: kata sumbebêkos gar endechetai ep'amfoterôn metalambanein tôn dikaiôn. (ENV, 91136 a 23-27).

${ }^{12}$ Ver capítulo anterior e ENV, 8. Utilizo a terminologia “objetivamente justo" para me referir ao que é justo ou injusto de acordo com a definição de EN V, 1, i.e., de acordo com aquilo que adiante chamarei de condições objetivas do justo. O mesmo se dá com a terminologia "objetivamente injusto".

${ }^{13}$ homoiôs de dêlon hoti kai epi tôn adikôn: ou gar tauton to tadika prattein tôi adikein oude to adika paschein tôi adikeisthai, homoiôs de kai epi tou dikaiopragein kai dikaiousthai; adunaton gar adikeisthai mê adikountos ê dikaiousthai mê dikaiopragountos. (ENV, 91136 a 26-29).

${ }^{14}$ Quem age voluntariamente conforme o que é injusto não necessariamente age injustamente, pois pode tê-lo feito com a concordância de quem sofre o que é injusto.

15 ê ouk orthos ho diorismos, alla prostheteon tôi blaptein eidota kai hon kai hôi kai hôs to para tên ekeinou boulêsin: blapteitai men oun tis hekôn kai tadika paschei, adikeitai d'outheis hekôn: outheis gar bouletai, oud'ho akratês, alla para tên boulêsin prattei: oute gar bouletai outheis ho mê oietai einai spoudaion, ho te akratês hou ouk oietai dein prattein prattei. (ENV, 91136 b 3-9).

\section{Referências bibliográficas:}

ARISTÓTELES. 1984. Nicomachean Ethics. Tradução de W. D. Ross revisada por J. O. Urmson. In: BARNES, J. (Organizador). The Complete Works of Aristotle: The revised Oxford translation. Tomo II. Princeton:

Princeton University Press.

ARISTÓTELES. 1999. Nicomachean Ethics. Tradução de Terence Irwin. 2. ed. Indianápolis: Hackett.

ARISTÓTELES. 2001. Ética a Nicômacos. Tradução de Mário da Gama Kury. 4. ed. Brasília: Editora UnB.

ARISTÓTELES. 1934. Nicomachean Ethics. Edição bilíngue com tradução de H. Rackham. (Loeb Classical Library). Cambridge, Massachusetts.

BEVILAQUA, Clovis. 1903. Do enrequecimento illegitimo. Logar que se lhe deve assignalar nos Codigos Civis. Revista Academica da Faculdade de Direito do Recife, Recife, ano XI, pp. 3-13. 
BOSTOCK, David. 2000. Aristotle's Ethics. Oxford: Oxford University Press.

GORDLEY, James. 2006. Foundations of Private Law. Oxford: Oxford University Press.

IRWIN, Terence. 1988. Aristotle's First Principles. Oxford: Clarendon. KRAUT, Richard. 2002. Aristotle. Oxford: Oxford University Press. MILLER JR., Fred D. 1995. Nature, Justice, and Rights in Aristotle's Politics. Oxford: Clarendon Press.

VILLEY, Michel. 1977. Esquisse historique sur le mot responsable. Archives de philosophie du droit, n. 22, p. 45-58.

VILLEY, Michel. 2003. Filosofia do direito. Tradução de Márcia Valéria Martinez de Aguiar. São Paulo: Martins Fontes.

WEINRIB, Ernest J. 1995. The Idea of Private Law. Cambridge, Massachusetts: Harvard University Press. 


\title{
Potentia e potestas no Leviathan de Hobbes ${ }^{1}$
}

\author{
Maria Isabel Limongi \\ belimongi@yahoo.com.br \\ Universidade Federal do Paraná (UFPR), Curitiba, Brasil
}

resumo no Leviathan, o poder (power) pode ser entendido em dois sentidos, cuidadosamente diferenciados em sua versão latina pelo emprego dos termos potentia e potestas para traduzir, a depender do contexto e do tipo de poder em questão, o inglês power. Potentia e potestas, embora sejam tipos de poder de natureza distinta - um, o poder físico que os corpos têm de produzir efeitos uns nos outros; outro, o poder jurídico, do qual resultam efeitos jurídicos como a própria justiça -, estão mutuamente implicados na trama das representações jurídicas. Esse artigo pretende explorar as consequências que se seguem deste conceito ambivalente do poder para se pensar a justiça e o direito natural.

palavras-chave Leviathan; Hobbes; Poder; Direito; Potentia; Potestas; Jus

No quadro das ciências do capítulo IX do Leviathan, a ciência do justo e do injusto consta, ao lado da poesia, da retórica e da lógica, como uma ciência que trata das consequências de um ato de linguagem (speech). Este ato consiste no contrato, no qual reside, segundo Hobbes, toda a fonte da justiça. Onde não há contratos, escreve ele no Leviathan, não há transferência de direito (right), "e consequentemente nenhuma ação é injusta (unjust)" (HOBBES, 1985, p. 202). ${ }^{2}$

Ao fundar a justiça nos contratos, Hobbes lhe confere uma relativa autonomia em relação à natureza, às paixões e opiniões humanas. Na ciência do justo e do injusto, não se trata de retirar consequências das paixões humanas, como na ética (cf. quadro das ciências); não se trata de saber como os homens efetivamente se comportam e como formam suas opiniões, segundo causas naturais. Trata-se de calcular obrigações e direitos a 


\section{4}

partir do que os homens dizem e de como se representam pela palavra no ato contratual. A justiça é, assim, da ordem do artificio e não da natureza. Ela é uma instituição humana.

Por outro lado, ao mesmo tempo em que circunscreve com precisão o plano próprio e específico da normatividade jurídica, Hobbes desenvolve no Leviathan, especificamente nos capítulos X a XIII, uma certa teoria do poder ou, mais precisamente, uma descrição das relações naturais entre os homens enquanto relações de poder, no qual o poder é concebido de maneira talvez inédita, pelo menos no grau de precisão atingido por Hobbes no Leviathan - como juridicamente neutro. Relações de poder, que em última instância são relações de guerra, não são jurídicas. Não são nem justas nem injustas. Elas simplesmente ocorrem e podemos calcular como ocorrem, quando conhecemos suas causas naturais. Há, assim, para Hobbes uma diferença de natureza entre as relações sociais entendidas e descritas em termos de relações de poder e as relações jurídicas. Relações jurídicas não são relações de poder. Relações de poder não são jurídicas.

Tendo assim estabelecido com precisão a distinção entre as esferas e escapado da alternativa de reduzir relações jurídicas a relações de poder ou relações de poder a relações jurídicas, Hobbes se vê diante da questão de pensar a relação entre essas esferas distintas. Pode-se dizer que a questão da relação entre direito e poder é uma questão, por excelência, hobbesiana.

Com o fim de mostrar como essa questão se coloca para Hobbes e como essa relação é pensada no Leviathan, nos propomos a fazer o seguinte percurso. Primeiro, reconstruiremos em linhas gerais a teoria do poder presente nos capítulos $\mathrm{X}$ do Leviathan, apontando para o que ela traz de novo e importante, a saber, um conceito não jurídico de poder, entendido enquanto potentia (a se distinguir, como veremos do poder como potestas, que é o poder juridicamente qualificado), e um modo inédito de conceber as relações sociais a partir daí. Em seguida, analisaremos as consequências dessa teoria para pensar o direito natural e civil. Queremos mostrar que, embora o direito natural e o civil não possam ser pensados em termos de relações de poder (potentia), e embora relações de poder sejam juridicamente neutras, não sendo em si mesmas nem justas nem injustas, elas têm efeitos jurídicos importantes. Ou seja, a esfera da justiça e do direito, mesmo se diferente, e por isso mesmo, está em relação com a esfera do poder. 
No âmbito do direito civil, indicaremos o interesse de se pensar essa relação no que diz respeito a dois temas centrais no pensamento hobbesiano, aos quais não se deu até agora a devida importância - o tema da resistência e o tema do governo, ambos relacionados ao problema da dissolução do Estado, o verdadeiro horizonte do pensamento jurídico e político de Hobbes. Queremos mostrar que é a necessidade de pensar a possibilidade da dissolução do Estado (o que nos leva a tomar Hobbes menos como o teórico do Estado todo poderoso do que como o do Estado sob o risco sempre presente da dissolução), o que leva Hobbes a articular, do modo como queremos mostrar que articula, direito e poder - ou: potestas e potentia.

A tradição jusnaturalista moderna - ou seja, uma certa escola do pensamento jurídico que se desenvolveu na Inglaterra, na França e na Alemanha nos século XVII e XVIII e que se reconhecia como herdeira de Grotius - pensou o direito (jus) enquanto uma potestas, e o poder - a potestas enquanto um direito (jus). Isso fica particularmente claro em Pufendorf quando este define no início do De jus naturae et gentium o poder (potestas) como "aquilo pelo que um homem está apto (potest) a fazer algo legitimamente e com efeito moral" (PUFENDORF, I, 1, xix). Trata-se do poder de agir juridicamente, um poder que pode se exercer (a) sobre as pessoas, como a liberdade, que é o poder sobre a própria pessoa e ações, e o Imperium, que é o poder sobre outras pessoas; ou (b) sobre as coisas, como a propriedade (dominium), que é o poder sobre as próprias coisas, e o Servitus, o poder sobre as coisas dos outros.

O poder é, assim, poder legítimo.Trata-se de um poder que é um direito, como Pufendorf esclarece em seguida ao definir o direito como "a qualidade moral pela qual com justiça governa-se (imperamus) as pessoas ou se possui as coisas (res tenemus)" (I, 1, xx), isto é, a qualidade pela qual se possui os poderes sobre pessoas e coisas acima discriminados. Ciente da sobreposição dos sentidos dos conceitos de direito e poder, Pufendorf esclarece que o poder expressa a presença de tal qualidade, a sua efetividade, enquanto o direito se refere à maneira (legítima - recte) pela qual se tem ou se exerce o poder. 
Assim, enquanto a operação de uma pessoa moral e capacidade de produzir efeitos morais, o poder é juridicamente qualificado, sendo isso precisamente - o caráter legítimo do poder - aquilo para que o conceito de direito aponta, a diferença entre os conceitos residindo nos diferentes modos pelos quais se visa a mesma operação ou qualidade de uma pessoa moral. Tanto é assim que há determinados atributos morais para os quais é dificil discernir se são melhor expressos pelo conceito de poder ou de direito:

Para falar acuradamente, há muitas coisas normalmente computadas sob a noção de direito que seriam melhor denominadas uma composição de poder e direito, no sentido estrito dessas palavras, e que envolvem ou supõem, ainda, alguma obrigação, honra, ou algo semelhante. Assim, o direito ou privilégio de ser um cidadão, contém tanto o poder de exercer com plena virtude todos os atos pertinentes à cidadania, como os direitos de gozar dos beneficios que lhe são próprios, supondo ainda na pessoa uma obrigação diante da corporação. (Id. I, 1, xx)

A obrigação, por sua vez, é "aquilo a que um homem se vê na necessidade moral de praticar, admitir ou se submeter." (Id. I, 1, xxi) e consiste numa contraparte indispensável do poder/direito de produzir efeitos morais, já que esse poder/direito se exerce de maneira a gerar obrigações e conceder licenças.

Como se sabe, a noção de pessoa moral à qual corresponde um poder/ direito de agir e produzir efeitos jurídicos é desenvolvida por Pufendorf a partir de Grotius, que, numa célebre passagem do De juri belli ac pacis, já afirmava que o direito pode significar, entre outras coisas, uma "qualidade moral anexada à pessoa, habilitando-a a ter ou fazer algo com justiça" (GROTIUS, 2005, I, 1, iv). Esta passagem é frequentemente lembrada como o momento em que se põe em cena o que mais recentemente se passou a chamar de direitos subjetivos, aos quais normalmente se vê associado o nome de Grotius, como alguém que teria contribuído de maneira decisiva para a sua formulação moderna (Cf.VILLEY, 2009).

O direito, entendido como uma qualidade moral da pessoa, é, segundo Grotius, uma faculdade ou uma aptidão da pessoa. Esta faculdade pode ser entendida nos termos (1) de um poder (potestas - sobre nós mesmos ou sobre outros); (2) de uma propriedade; ou (3) de uma faculdade de demandar e conceder o que é devido. Trata-se assim de um direito/poder/obrigação 
em relação a pessoas e coisas, entendido nos termos da qualidade de uma pessoa moral. É daí que Pufendorf deriva a ideia de uma personalidade moral que cria efeitos morais, como um poder de constituir direito e demandá-lo. É a partir daí que Grotius, Pudendorf, assim como Locke - a tradição jusnaturalista moderna, de um modo geral - pensa o poder político: como um direito/poder de fazer leis, derivado da personalidade jurídica do governante. $\mathrm{O}$ poder é um direito. $\mathrm{O}$ direito é um poder.

Hobbes, porém, à diferença de Grotius, Pufendorf e Locke, não tem um conceito unívoco de poder. Pois ele o pensa não apenas como potestas, poder/direito de produzir efeitos jurídicos, como no contrato, mas também como potentia, poder físico. Leo Strauss talvez tenha sido o primeiro a chamar a atenção para esse ponto:

É com a filosofia política de Hobbes que o poder se tornou pela

primeira vez eo nomine um tema central. Considerando-se o fato de que, de acordo com Hobbes, a própria ciência existe em vista do poder, pode-se denominar a filosofia de Hobbes como um todo a primeira filosofia do poder. "Poder" é um termo ambíguo. Ele traduz potentia, de um lado, e potestas (ou jus, ou dominium), do outro. Ele significa tanto o poder "físico" como o poder "legal". A ambiguidade é essencial: apenas se potentia e potestas caminham juntas, pode haver garantia de atualização da ordem social correta (right social order). O Estado, enquanto tal,é ao mesmo tempo a maior força humana e a mais alta autoridade humana (STRAUSS, 1968, p.194).

Leo Strauss chama a atenção para o que há de novo na teoria hobbesiana do poder e para o que faz do poder um tema central na filosofia de Hobbes. O poder não é apenas potestas, mas potentia, sendo que a potestas contem algo de potentia - logo (ainda que esta não seja uma consequência retirada por Strauss): o poder não é para Hobbes um conceito inteiramente jurídico.

Esse conceito não jurídico do poder é apresentado no capítulo $\mathrm{X}$ do Leviathan, que desenvolve, não sem uma série de modificações importantes, 
o conceito de poder esboçado dez anos antes na parte 1, capítulo VIII do The Elements of Law, em que se faz menção ao poder em um capítulo dedicado às paixões. Para falar das paixões que envolvem uma concepção do futuro, diz Hobbes, é preciso antes falar do poder. E seguem-se alguns parágrafos sobre o poder, que constituirão o núcleo do futuro capítulo X do Leviathan, em que o poder ganha um tratamento a parte, como um conceito que por si só merece atenção, não mais simplesmente como um capítulo da teoria das paixões.

De que poder se trata nessa passagem do The Elements of Law? Trata-se de uma capacidade de produção das coisas, que no De Corpore Hobbes vai assimilar à causa eficiente. "O poder do agente e a causa eficiente são a mesma coisa", com a diferença que a causa se diz de um efeito passado e o poder de um efeito a ser produzido no futuro (HOBBES, 1999, II, X, 1). Esse poder está concernido nas paixões que envolvem uma concepção do futuro porque essa concepção consiste justamente na atribuição de um poder a algo (o poder de produzir um efeito) que projeta no futuro o que se sabe no passado acerca da capacidade de produção da coisa em questão. O poder de que aqui se trata é, em suma, a velha potência aristotélica, pensada em termos de uma capacidade atual de produção.

No entanto, o que há de novo nesse conceito de poder não é apenas que ele seja pensado em termos de uma capacidade atual, mas também - o que nos interessa aqui - o uso que Hobbes faz dele para pensar a relação entre os homens e o modo como as paixões se formam nessas relações - se quisermos, a aplicação antropológica que Hobbes lhe dá. Pois, não é toda e qualquer concepção de poder, entendido como um poder de produção das coisas, mas a concepção do nosso próprio poder a que está envolvida na formação das paixões. Assim, tendo anunciado que é preciso falar do poder porque certas paixões envolvem uma concepção dele, o texto prossegue tratando do poder dos homens:

Por este poder quero dizer o mesmo que as faculdades do corpo e da mente, mencionadas no primeiro capítulo, a saber, as do corpo, a nutritiva, generativa e motiva, e as da mente, o conhecimento. E além destas, outros poderes que se adquirem por seu intermédio, como a riqueza, posição de autoridade (place of authority), amizade ou favor, e a boa fortuna, que não é outra coisa senão o favor de Deus Todo Poderoso. (HOBBES, 1969, I, 8, 4) 
E o que está em jogo não é apenas a concepção de nosso próprio poder, mas a concepção que fazemos de nosso poder relativamente ao dos outros homens. Assim segue o texto:

Porque o poder de um homem resiste e enfraquece os efeitos do poder de outrem, o poder não é mais do que o excesso de poder de um homem sobre outro. Pois, poderes iguais opostos destroem um ao outro e esta oposição é denominada disputa (contention). (idem)

Há três ideias importantes aí: (1) que as faculdades humanas consistem em poderes, em capacidades de produção ou ação; (2) que esses poderes são instrumentos para se adquirir mais poder e (3) que o poder de um homem reside no excesso de seu poder sobre o outro. Hobbes parte daí, dessa aplicação de um conceito físico do poder enquanto capacidade de produção das coisas a um contexto antropológico, para elaborar uma teoria do poder (que não o soberano) no capítulo X do Leviathan.

Num ganho em precisão com relação ao The Elements of Law, Hobbes começa esse capítulo definindo o poder (potentia, no Leviathan latino) como "os meios presentes [de que um homem dispõe] para obter o que lhe aparece como um bem futuro" (HOBBES, 1985, p. 150). Em seguida, nomeia os dois tipos de poder elencados no The Elements of Law, como, de um lado, o poder natural (as faculdades do corpo e da mente) e, do outro, os poderes instrumentais, "que são adquiridos por meio daqueles ou pela fortuna" e que - uma observação que faltava no The Elements of Law - "são meios ou instrumentos para se adquirir mais poder”. Essa observação é importantíssima. Pois ela define o objeto do capítulo - um novo objeto em relação ao The Elements of Law - que não é outro senão os modos de instrumentalização do poder.

Mais especificamente, trata-se para Hobbes de tematizar os modos de instrumentalização social do poder. Pois, logo após definir o poder e distinguir entre poder natural e instrumental, Hobbes descreve três modos pelos quais os homens podem compor o seu poder com o dos outros, e, nesse sentido preciso, instrumentalizá-lo, isto é, adquirir mais poder. Um desses modos é o do Estado, o maior poder (potentia) humano, "composto pelos poderes de vários homens (ex plurimorum hominum potentiis), unidos por consentimento numa só pessoa, natural ou civil, que tem o uso de todos os seus poderes (potentiae omnium) na dependência 
de sua vontade" (HOBBES, 1985, p. 150; 1966, p. 68). Mas Hobbes não menciona o poder soberano senão para afastá-lo do horizonte de sua investigação imediata, que se detém no outro modo de compor poderes, que é aquele pelo qual os homens, usando de seus poderes cada um conforme a sua própria vontade, formam facções ou coligações de facções. Esse modo de composição de poder se distingue assim expressamente da via jurídica da soberania. ${ }^{3}$ Onde existem facções - num contexto social, portanto - o poder de um homem (aquele diferencial de poder que ele tem sobre os outros) reside num poder de cooptação de amigos e servidores. "Ter servidores é poder; e ter amigos é poder: porque são forças unidas" (HOBBES, 1985, p. 150). Trata-se assim de uma capacidade de usar o poder reunido a favor dos próprios fins. E Hobbes passa então a explicar como isso se dá.

O eixo da cooptação é o valor, que Hobbes define da seguinte maneira: "o valor de um homem, tal como o de todas as outras coisas, é seu preço; isto é, tanto quanto seria dado pelo uso de seu poder. Portanto, não absoluto, mas algo que dependente da necessidade e julgamento de outrem" (HOBBES, 1985, pp. 151-152). É em vista da avaliação que os homens fazem dos poderes uns dos outros que eles escolhem usar do próprio poder aliando-se, submetendo-se ou opondo-se aos poderes dos outros. Ser capaz de reunir forças em torno de si é ser bem valorizado.

Ou seja, o poder é fundamentalmente relacional. Ele não é algo que um indivíduo disponha senão por meio da opinião que os outros fazem dele, de seu poder e do uso que podem fazer dele. É na medida em que são valorizados que os homens têm poder, ou melhor, um diferencial de poder em relação aos outros homens, tornando-se assim capazes de reunir forças em torno de si. Daí a importância do conceito de honra, que Hobbes define como "a manifestação do valor que mutuamente nos atribuímos” (HOBBES, 1985, p. 152), na caracterização do que podemos entender como uma dinâmica social do poder. Nessa dinâmica, o poder significado na honra ou a honra enquanto um signo do poder passa a valer como o próprio poder, na medida em que, ao significar uma capacidade de cooptação, a honra resulta em mais poder. Compreende-se assim que a disputa se dê para Hobbes não apenas na forma de uma disputa de forças, mas, sobretudo, na forma de uma disputa pela glória e reputação, que são signos do poder e elas mesmas poder. ${ }^{4}$ 
Assim, o poder é pensado no Leviathan como uma capacidade relacional. Enquanto no The Elements of Law ele é pensado como uma qualidade dos indivíduos, comparada com a dos outros, mas que o indivíduo possui independentemente dos outros, no Leviathan, o poder de cada um se determina somente no interior de uma certa dinâmica de disputa pelo poder (a guerra), que, mais do que um contexto relacional, é um contexto social de inscrição do poder, já que a disputa se dá na forma de uma disputa pelo reconhecimento social do poder, que é o valor e a honra.

Trata-se, além disso, de pensar o poder enquanto um modo não jurídico de reunião de forças, alternativo ao da soberania, e que se apoia, não na razão, mas na opinião que os homens fazem uns dos outros e no valor que mutuamente se atribuem. Hobbes pensa o poder, nesse contexto, em continuidade com o modo como Maquiavel o pensou, isto é, enquanto uma reunião de forças ou capacidade de realização conjunta que passa fundamentalmente pela construção de uma boa imagem ou pela capacidade de se fazer bem representar pelos outros. ${ }^{5} \mathrm{O}$ poder assim pensado, enquanto a conjunção entre aparência e força, é expressa com exatidão num dos fragmentos dos Pensées de Pascal, que segue também nesse ponto Maquiavel e Hobbes: "ser elegante não é por demais vão, pois é mostrar que um grande número de gente trabalha para si. (....) Quanto mais braços se tem, mais forte se é. Ser elegante é mostrar sua força” (PASCAL, 1963, fr. 95).

\section{II}

A questão que queremos colocar é: o que essa nova teoria do poder traz de importante para pensar o direito e a justiça?

Hobbes se alinha perfeitamente à linhagem jusnaturalista (tal como a definimos aqui: como uma tradição que pensa o poder como um direito e o direito como um poder, a partir da noção de pessoa), a qual de resto se vê muitas vezes vinculado (Cf. especialmente TUCK, 1995), ao referir o direito civil à pessoa do Soberano, que age, segundo Hobbes, por autoridade, sendo que por autoridade se deve entender o "direito de empreender algum ato" (HOBBES, 1985, p. 217), o qual, por sua vez, implica determinadas obrigações. É todo um vocabulário e um modo de pensar que 
fazem de Hobbes um perfeito representante da tradição do direito natural oriunda de Grotius, de acordo com o modo como a caracterizamos aqui. No modo de pensar a soberania e o direito civil, Hobbes se põe num terreno desde o princípio jurídico, pensando a potestas como um direito e o direito como uma potestas.

Mas, o que dizer do direito natural? Ele seria também pensado por Hobbes nos mesmos termos de Grotius, Pufendorf e Locke, como uma potestas, um direito/poder de produzir efeitos jurídicos?

Que Hobbes não pense o direito natural como uma potentia é o que ele deixa claro na própria definição que oferece do direito natural: "o direito de natureza (...) é a liberdade que cada homem possui de usar seu próprio poder (potentia), da maneira que quiser, para a preservação de sua própria natureza, ou seja, de sua vida" (HOBBES, 1985, p. 189; 1974, p. 82). Consistindo o direito na liberdade de uso do poder, tal direito permanece o mesmo, seja o poder maior ou menor. É o que Hobbes esclarece, quando, após definir a liberdade em que consiste o direito natural como ausência de impedimentos externos, precisa: tais impedimentos "muitas vezes tiram parte do poder (potentia) que cada um tem de fazer o que quer, mas não podem obstar a que use o poder (potentia) que lhe resta, conforme seu julgamento e razão lhe ditarem" (HOBBES, 1985, p. 189; 1974, p. 82). O esclarecimento visa indicar o sentido preciso em que se deve compreender que um direito é restringido ou cancelado: não pela oposição de um outro poder (pois o poder cancela apenas um outro poder), mas por meio de uma obrigação, cancelando a liberdade de usar o poder como se queira, na qual consiste propriamente o direito.

Daí decorre a distinção entre o escravo e o servo. O primeiro, "guardado na prisão ou a ferros (...), não tem obrigação alguma, e pode, sem injustiça, destruir suas cadeias ou prisão e matar ou levar cativo seu senhor", ao passo que o servo, não estando submetido à prisão ou a ferros, se vê, contudo, obrigado por contrato a "não fugir nem praticar violência contra seu senhor” (HOBBES, 1985, p. 255; 1974, p. 128). Os vínculos jurídicos, que ligam o servo ao seu senhor, têm, portanto, uma natureza distinta das relações de poder, sobre as quais se assentam a escravidão. Tais vínculos se estabelecem por contrato, não se reduzindo, por essa razão, a uma relação de força e poder. 
Hobbes distingue, portanto, direito (jus) e poder (no sentido da potentia). O direito natural seria, então, potestas - o poder legítimo de empreender determinados atos, poder autorizado, fundado na pessoa natural do homem? Hobbes é muitas vezes lembrado como aquele que teria pensado o chamado direito subjetivo, ao qual Grotius teria dado a formulação moderna, fundamentalmente nos termos de uma liberdade. O que era para Grotius uma das qualidades inerentes à pessoa (o poder sobre si mesmo) entre outras (o poder sobre os outros e sobre as coisas), passa a ser, para Hobbes, a qualidade por excelência da pessoa. O homem é fundamentalmente uma pessoa dotada do direito ou da liberdade de constituir direitos (Cf. TUCK, 1995; para uma defesa contemporânea desse modo de conceber o direito, valendo-se de Hobbes, Cf. COLLIOT-THELÈNE, 2011, cap. 2). Nisso consistiria o direito natural. Este direito seria, assim, o atributo fundamental da pessoa natural do homem, da qual Hobbes parte, em conformidade com a tradição do direito natural moderno, para pensar o universo jurídico e político.

Mas, então, o conceito de poder enquanto potentia, o poder pensado em termos não jurídicos, trazido à cena por Hobbes, não teria nenhum impacto sobre o conceito de direito enquanto potestas? Hobbes teria duas teorias do poder sobrepostas? ${ }^{6}$ Contra essa conclusão caminha a leitura de Leo Strauss no ponto em que procuramos resgatá-la aqui, a saber, ali onde Strauss nos faz ver que a potestas de Hobbes está de algum modo perpassada pela potentia, assim como o jus pelas determinações da natureza física. Qual então o impacto dessa nova teoria do poder sobre o conceito hobbesiano de potestas, o poder juridicamente qualificado?

$$
* * *
$$

Podemos mensurar o impacto dessa nova teoria do poder se atentarmos para certos aspectos da definição hobbesiana de pessoa, que traz para o centro da cena um elemento que na tradição do direito natural permanece um elemento periférico da personalidade: seu caráter representativo. Pufendorf, provavelmente em alusão a Hobbes, entende que a pessoa representativa (aquela que age em nome de outrem) é um tipo de personalidade política, entre outras formas não representativas e não 


\section{4}

necessariamente políticas de personalidade (Cf. PUFENDORF, 1710, I, I, xii, p. 6). Para Hobbes, no entanto, a pessoa, seja lá de que tipo for, é sempre representativa.

Uma pessoa é aquele cujas palavras e ações são consideradas quer como suas próprias quer como representando as palavras e ações de um outro homem, ou de qualquer outra coisa a que sejam atribuídas, seja com verdade ou por ficção. Quando elas são consideradas como suas próprias ele se chama uma pessoa natural. Quando são consideradas como representando a palavras e ações de um outro, chama-se-lhe uma pessoa fictícia ou artificial. (HOBBES, 1971, p. 100)

A definição de pessoa natural, como aquela cujas palavras e ações são consideradas como suas, é derivada de uma definição mais ampla de pessoa, que abriga a noção de pessoa fictícia e que faz do ato de atribuição de palavras e ações a uma instância qualquer (seja homem ou coisa, natural ou fictícia) o ato fundador da própria personalidade. Não há pessoa senão ali onde se estabelece uma relação entre atos e palavras e o seu autor, por uma forma de representação, cujo sentido Hobbes se põe a explorar.

A palavra pessoa é de origem latina. Em lugar dela, os gregos tinham prósopon, que significa rosto, tal como em latim persona significa o disfarce ou a aparência exterior de um homem, imitada no palco. (...) E do palco, a palavra foi transferida para qualquer representante da palavra ou da ação, tanto nos tribunais como nos teatros. De modo que uma pessoa é o mesmo que um ator, tanto no palco como na conversação corrente. (id. ib.)

A pessoa é, assim, fundamentalmente, um representante ou uma representação, diante dos outros. Ela é uma máscara que guarda, mesmo no que diz respeito à pessoa natural, uma distância e exterioridade em relação ao que representa. Sendo assim, a pessoa natural não equivale ao homem. Ela é, antes, o seu representante ou sua representação jurídica. Ela é o homem na medida em que seus atos e palavras são considerados seus para fins de um cálculo jurídico, em relação a outros homens igualmente representados numa relação jurídica. Mas o homem não se confunde com essa representação jurídica de si mesmo. Ele está dado, como um corpo, um feixe de paixões e movimentos voluntários que não têm em si mesmos, independente dessa representação, um valor jurídico, que não são por 
natureza nem legítimos, nem ilegítimos, que não geram direitos, nem obrigações, mas apenas outros movimentos.

Isso está de acordo com o modo como Hobbes define a liberdade natural do homem a partir de uma definição de liberdade mais ampla, aplicada aos corpos em geral, enquanto a liberdade do corpo-homem:

Liberdade significa, em sentido próprio, a ausência de oposição

(entendendo por oposição os impedimentos externos do movimento);

e não se aplica menos às criaturas irracionais e inanimadas do que às racionais." (id. p. 133)

$(\ldots)$

E conforme a esse significado próprio e geralmente aceito da palavra, um homem livre é aquele que, naquelas coisas que graças a sua força e engenho (wit) é capaz de fazer, não é impedido de fazer o que tem vontade de fazer. (id. ib.)

Essa liberdade natural ou corporal não é ainda direito natural. Ela é potentia, capacidade de movimento que pode ser restringida por outra potentia e que, como vimos, não equivale ao direito natural, segundo a definição que Hobbes lhe dá. Assim como não faz sentido dizer que a água que corre pelo canal tem o direito de se mover, mas apenas que ela tem o poder de se mover, não faz sentido dizer que a liberdade natural do homem, definida nesses termos, constitui um direito. A liberdade do homem só tem um sentido propriamente jurídico, só constitui direito, em relação à soberania, enquanto liberdade dos súditos, que reside no silêncio das leis ou naquilo que o soberano não pode obrigar tendo em vista os direitos e deveres derivados do contrato. É nesse plano, e relativamente ao ato contratual que institui a soberania, que faz sentido falar em direito natural. Mas, se é assim, onde situar exatamente esse direito? Se, conjuntamente com a obrigação civil, ele deriva do contrato, então ele não seria propriamente natural, mas artificial?

Diz-se do direito que é natural quando ele é o atributo de uma pessoa natural - o homem. Este, na medida em que é considerado uma pessoa, é o sujeito do direito natural. Contudo, o homem não é por natureza e sim por artifício uma pessoa. O homem é, por natureza, um corpo. Enquanto tal, ele é dotado de uma liberdade, uma certa potentia de movimento, que não é em nada restringida pelas obrigações que ele assume quando se 
deixa representar numa relação jurídica como uma pessoa e que se apresenta como uma espécie de fundo não jurídico das relações jurídicas.

É no jogo não jurídico das potentiae que Hobbes busca as razões para que o homem se deixe representar num campo jurídico. Se ele não aceitar essa representação, o resultado é uma vida miserável e curta. É ainda à potentia que Hobbes apela para dizer que, malgrado a instituição do Estado, o homem permanece tão livre quanto antes para não cumprir suas obrigações: nada restringe o seu poder (potentia) de desobedecer, ainda que lhe falte o direito para tanto.

Como mostrou Skinner, este não é um elemento menor na argumentação hobbesiana (Cf. SKINNER, 2008). Mas o que está em jogo aí não é apenas, como ele faz ver, uma redefinição da liberdade de maneira a responder àqueles que a defendiam em termos republicanos, de modo a torná-la compatível com a monarquia. Trata-se, além disso, e sobretudo, de mostrar que o homem só é um sujeito de direito na medida em que o queira, e de pensar essa motivação, a motivação para se tornar um sujeito de direitos, num plano pré-jurídico. Trata-se ainda de mostrar que o homem permanece livre para, caso queira, desinvestir-se de sua personalidade jurídica, de sua potestas e sua capacidade de produzir efeitos jurídicos, para recolocar-se fora do mundo jurídico enquanto pura potentia. Trata-se também de apontar para a relevância jurídica dessa possibilidade sempre em aberto em função do caráter ambivalente do poder.

\section{III}

Como se sabe, malgrado toda a ênfase colocada na questão do dever de obediência e das obrigações diante do Estado, Hobbes reserva um lugar bastante significativo ao direito de resistência. Trata-se do que ele denomina no cap. 21 do Leviathan, a "verdadeira liberdade dos súditos", que está naquelas coisas que "embora ordenadas pelo soberano, não obstante [os súditos] podem sem injustiça recusar-se a fazer.” (HOBBES, 1985, p. 268)

Para saber quais são esses direitos "é preciso examinar quais são os direitos (rights) que transferimos no momento em que criamos o Estado", uma observação que corrobora o ponto sobre o qual viemos insistindo - que a liberdade, enquanto um direito de resistir, qualifica-se enquanto tal 
no ato do contrato, tratando-se de uma qualidade jurídica do contratante, o direito ou a potestas de fazer legitimamente o que não pode ser transferido por contrato. Assim, não sendo possível transferir por contrato o direito de defender a própria vida, os súditos não podem ser obrigados a se matar, mutilar ou ferir, a se autoacusar ou confessar um crime e a enfrentar missão perigosa. Eles têm, nesses casos, o direito ou a liberdade juridicamente qualificada, a potestas de resistir.

As razões desse direito remontam à lógica do contrato. Vimos que o contrato envolve uma representação de si, no que reside a constituição da personalidade jurídica do contratante e o fundamento da ciência jurídica, que não é senão o cálculo das consequências da palavra empenhada nos contratos. Ora, essa representação e personificação só são possíveis se o contratante puder vislumbrar que por meio do contrato garantirá um bem para si. Pois, contratos são atos voluntários e atos voluntários são atos pelos quais se visa algum bem aparente para si. Daí porque contratos no estado de natureza, assim como os contratos em que alguém se comprometa a não resistir à violência alheia, não são válidos - porque não se pode esperar nenhum bem desse compromisso, que, por essa razão, não vincula, não impõe obrigação. O problema é formal: não se podem compreender essas palavras como sendo do contratante. Ele não pode representar-se a si mesmo enquanto um homem - um corpo natural e feixe de paixões - e constituir-se como uma pessoa jurídica nessas condições.

No caso dos contratos estabelecidos no estado de natureza, esse problema formal é resolvido pela garantia de que o outro cumprirá a sua parte, se não porque compreende a necessidade de cumprir contratos, ao menos porque será forçado a fazê-lo, pelo medo da punição.Tem-se assim a garantia de obter os bens visados pelos contratos, e o contratante, podendo desse modo ver-se representado em relações contratuais, encontra-se obrigado por elas. Essa garantia, sabemos, é dada pelo Estado, a quem cabe punir aqueles que desrespeitam a palavra empenhada.

A punição ou sua simples possibilidade (o medo) assume assim um papel fundamental na instituição do universo jurídico. Como ninguém está propriamente obrigado a cumprir com a lei de natureza que prescreve a necessidade de fazer contratos e cumpri-los, como permanece efetiva a liberdade física de não se fazer contratos, e, consequentemente, o direito de não cumpri-lo sob o pretexto da insegurança que essa liberdade física 
acarreta, é preciso de algum modo fazer obstáculo (que só pode ser físico) a essa liberdade - no que entra em cena a potentia do Estado. Que a potentia tenha um papel a cumprir nos contratos, e que seja, portanto, juridicamente relevante, é o que Hobbes afirma reiteradamente quando insiste que sem a espada soberana - uma caracterização inegavelmente material do poder do Estado - não há contratos válidos.

É preciso compreender corretamente o que está em jogo aí, evitando o engano em que muitos incorrem de pensar que o medo da espada é o que funda a obrigação contratual, ou seja, que alguém só se vê obrigado a cumprir um contrato na medida em que teme a punição. Não é este o raciocínio de Hobbes. Se assim fosse, perderiam-se de vista a natureza específica dos vínculos jurídicos enquanto vínculos de palavras e a diferença de natureza entre a esfera jurídica e a esfera das relações de poder.

Ao comparar a injustiça, que reside no descumprimento de um contrato, a uma contradição lógica, dizendo que ela "é de algum modo semelhante àquilo que nas disputas das escolas se chama absurdo" (HOBBES, 1985, p. 191), Hobbes deixa claro que o fundamento da obrigação está no compromisso com a palavra dada e com a representação coerente de si mesmo no ato contratual. O medo não é, portanto, o seu fundamento. Mas ele é a condição para que cada um possa representar-se coerentemente a si num contrato e, a partir daí, instituir obrigações. O medo (entenda-se: daquele com quem se contrata e não do próprio contratante, que se compromete pela palavra) é, assim, a condição material da validade formal dos contratos.

$\mathrm{O}$ mesmo se aplica à potentia do Estado ou à espada soberana. A potentia soberana é uma condição da sua suma potestas, fundada no contrato. Compreende-se assim que os dois tipos de poder se entrelacem e porque a potestas do Estado tem que necessariamente vir acompanhada de potentia, sem, no entanto, confundir-se com ela. Se levarmos em conta que esta bivalência do poder está presente não apenas na soberania, como também no súdito que resiste, o qual, no momento da resistência, recobra por detrás da potestas a potentia de resistir, e que isso, por sua vez, conduz a potestas soberana a agir enquanto potentia de punir, podemos avaliar as consequências jurídicas que se seguem do que primeiramente se apresenta como um choque entre os direitos de punir e o de resistir. ${ }^{7}$

Trata-se, com efeito, num primeiro momento, do choque entre a potestas da soberania e a dos súditos. De um lado, o soberano tem direito ou o 
poder legítimo de punir, mesmo que a punição seja iníqua, pois o direito de punir é condição da realização do fim de soberania, que é a proteção. Do outro, o súdito, mesmo quando justamente punido, pode (tem a potestas de) resistir, pois não se pode abdicar por contrato do direito de defender a própria vida. Ora, esse choque, uma vez em exercício, se efetiva como um choque entre potentiae, já que o direito em questão é a liberdade de usar da própria potentia da maneira que se queira. As consequências jurídicas disso são consideráveis e não se limitam à dissolução das relações jurídicas do Estado e do súdito resistente, mas chegam ao limite da dissolução completa dos vínculos jurídicos entre os homens e do retorno ao estado de natureza ou de guerra.

Essa possibilidade deve ser levada a sério. Pois, no choque entre a potestas/potentia de punir e a de resistir não se tem sempre um Estado todo poderoso de um lado e um súdito impotente do outro. É o que indica Hobbes numa passagem capital:

Ninguém tem a liberdade de resistir à espada do Estado em defesa de outro homem, culpado ou inocente, porque essa liberdade priva a Soberania dos meios para nos proteger, sendo portanto destrutiva da essência mesma do governo. Mas no caso em que um grande número de homens juntos tenha já injustamente resistido ao poder Soberano ou cometido algum crime capital, pelo qual cada um deles espera a morte, eles têm ou não a liberdade de se unirem e se ajudarem e defenderem um ao outro? Certamente que têm. Pois não fazem senão defender suas vidas, o que o homem culpado pode fazer (may do / licet) tanto quanto o inocente." (HOBBES, 1895, p. 270; 1966, p. 167)

Assim, a resistência de um indivíduo pode se tornar facilmente e com justiça a resistência de um grupo e, como na resistência a potestas se faz potentia de resistir, é a potentia do Estado que se vê primeiramente afetada, mas, por derivação, também sua potestas, já que “a obrigação dos súditos para com o soberano (suma potestas) dura enquanto, e apenas enquanto, dura também o poder (potentia) mediante o qual ele é capaz de protegê-los" (HOBBES, 1985, p. 272; 1966, p.168).

Vê-se assim que a afirmação de que a liberdade corpórea ou a potentia dos súditos permanece a mesma no interior do Estado traz consigo consequências jurídicas importantes, não se tratando apenas de um artifício 
para fazer descer a monarquia absoluta goela abaixo da tradição republicana. O que está em jogo aí é a possibilidade sempre em aberto da dissolução jurídica do Estado - da potestas em potentia.

Essa possibilidade se abre juridicamente, a partir da potestas ou direito de resistência. Tudo se passa então como se o tecido jurídico do Estado encontrasse no direito de resistência um ponto de esgarçamento pelo qual todo o jogo não jurídico das potentiae, tal como descrito no capítulo $\mathrm{X}$ do Leviathan, adquirisse relevância jurídica, na medida em que a resistência torna juridicamente possível o desmanche parcial e no limite integral do tecido jurídico. Evitar esse desfecho é papel do governo.

\section{IV}

A temática do governo em Hobbes, a qual se dá pouca importância em favor da temática jurídica do Estado, pode ser pensada a partir da distinção entre dois tipos de direitos do soberano.

De um lado, há os direitos que se seguem diretamente do pacto de instituição da soberania enquanto um pacto de autorização, isto é, os direitos que se seguem como consequência necessária dos termos dessa autorização. Quando a multidão reunida pactua de modo a ceder a um homem ou assembleia de homens o direito de representá-la, ou, o que dá do mesmo, quando autoriza todos os atos desse homem ou assembleia como se fossem seus, ela está, por este mesmo ato através do qual é instituído um poder soberano (soberano porque dispõe da "força e dos recursos de todos" (HOBBES, 1985, p. 228), reconhecendo que este poder não pode: (1) ser transferido; (2) ser confiscado; (3) ser protestado pela minoria; (4) ser acusado de injúria; (5) ser punido. No conjunto, tais direitos conferem ao poder soberano um caráter absoluto, posto que juridicamente incontestável, no que concerne ao direito de exercer todos os seus atos. $\mathrm{O}$ Estado é esse poder soberano e absoluto na medida em que instituído por e derivado do contrato. Nesse sentido, ele é potestas.

Por outro lado, há os direitos que se derivam da finalidade para a qual foi instituída a soberania em seu caráter absoluto. "Visto que o fim dessa instituição é a paz e a defesa de todos, e visto que quem tem direito a um fim tem direito aos meios" (HOBBES, 1985, p. 232), cabe ao soberano 
o direito de fazer tudo o que considere necessário à paz e segurança comuns. Tais direitos não se deduzem diretamente, como os primeiros, do contrato, mas se determinam a partir dos efeitos, isto é, do cálculo das consequências que se seguem do exercício desses direitos para a realização dos fins da soberania, o estabelecimento e a manutenção da paz entre os homens. Assim, são direitos do soberano: (1) ser juiz das doutrinas, no que são favoráveis ou contrárias à paz; (2) definir a propriedade, (3) ser juiz das controvérsias; (4) fazer a guerra e a paz com outros Estados; (5) escolher os magistrados, conselheiros e todos os funcionários; (6) recompensar e castigar; (7) conceder títulos de honra, ordem e dignidade.

Em conjunto, esses direitos determinam que cabe ao soberano o direito irrestrito a determinados meios de governo, sem os quais ele não se constitui como potestas soberana. O Estado implica, assim, um direito de governo, depreendido do contrato. Mas no que reside esse direito? Tratase do direito de fazer certo uso da potentia do Estado, que se exerce no plano físico ou fisiológico do controle das paixões, da formação das opiniões e da determinação material da vontade, como no caso da punição, entendida enquanto um ato de governo. Trata-se do direito de usar da potentia para produzir nos súditos efeitos não jurídicos.

Pode-se dizer que o papel do governo é o se assegurar ao Estado a potentia de que ele precisa para se impor enquanto potestas legislativa. Cabe, assim, à soberania, enquanto uma instância de governo, sustentar o Estado, que é a soberania enquanto consequência jurídica do contrato. Pois, ainda que os vínculos jurídicos que compõem o Estado sejam, de direito, relativamente ao ato de sua instituição, eternos, se o Estado não tiver o poder necessário para realizar o fim em vista do qual foi instituído, o pacto de sua instituição torna-se juridicamente nulo.Vale retomar a citação:"a obrigação dos súditos para com o soberano (sumam potestatem) dura enquanto, e apenas enquanto, dura também o poder (potentia) mediante o qual ele é capaz de protegê-lo" (HOBBES, 1985, p. 272; 1966, p. 168). Nessa frase, condensa-se toda a dificuldade do governo - a de garantir o poder (potentia) necessário para a manutenção dos vínculos jurídicos em que consiste o Estado.A questão do bom governo ou da prudência política não é assim, de modo algum, uma questão menor no raciocínio jurídico de Hobbes.

Pode-se entender que as "coisas que enfraquecem ou levam à dissolução de um Estado” (HOBBES, 1985, p. 363), as doenças do corpo político 
arroladas por Hobbes do capítulo XXIX do Leviathan dizem respeito ao mau governo. A metáfora do corpo enfermo, explorada para designar o Estado em vias de dissolução, indica que a questão se coloca em termos de um processo. Tendo em vista que o direito deriva-se do contrato, e, relativamente a ele, está de todo presente ou de todo ausente, é pela vertente da potentia que dá sustentação ao direito, a capacidade de governo - esta sim variável segundo as circunstâncias - que se coloca o problema da dissolução.

De um lado, há as doenças maiores, "aquelas que têm origem numa instituição imperfeita” (HOBBES, 1985, p. 363), para as quais o que está em jogo é uma má compreensão da ciência do justo e do injusto, levando à insuficiência do poder. Há, além dessas, as doenças menores, "não tão graves", como as doenças relacionadas à constituição de poderes paralelos ao do Estado, como a que se segue da concentração do seu tesouro nas mãos de alguns "por meio de monopólios ou contratos de renda pública" ou a que decorre da grande "popularidade de um súdito poderoso", ou ainda "da grandeza imoderada de uma cidade" ou do "grande número de corporações” (HOBBES, 1985, pp. 374-5). E, por fim, as doenças relativas a questões de política externa, como as que decorrem do alargamento excessivo dos domínios do Estado ou da vitória de um inimigo externo.

Tais doenças não são jurídicas, uma vez que "pela natureza de sua instituição", ou seja, relativamente ao pacto de instituição da soberania, os Estados "estão destinados a viver tanto tempo quanto a humanidade, ou quanto às leis de natureza, ou quanto à própria justiça que lhes dá vida" (HOBBES, 1985, p. 363). Os Estados são juridicamente eternos. É possível, porém, que não consigam assegurar a potentia necessária para sustentar o sistema de relações jurídicas em que eles consistem, para o que, entre outras coisas, e de maneira crucial, se requer a devida compreensão de sua natureza jurídica e dos seus direitos.

O que é difícil de assegurar é, portanto, a convergência material das vontades, a composição de forças, por trás do vínculo formal das vontades que formam o Estado pela via jurídica do contrato. Assegurar essa convergência é algo que está na dependência de um bom governo. Em vista dos perigos que o governo tem que evitar e os tipos de doença contra as quais deve se assegurar, pode-se dizer que o governo tem basicamente duas tarefas fundamentais. De um lado, governar as opiniões, (donde a 
recorrência do tema do controle das doutrinas por parte do Estado e da educação para a vida civil, para a qual Hobbes pensa ser o seu Leviathan um instrumento adequado e útil), pelo que se evitam as doenças maiores. Do outro, regular as relações sociais de poder, impedindo a constituição de poderes paralelos que se sobreponham ao poder do Estado, pelo que se combatem as doenças menores.

Pode-se então dizer que Hobbes pensa o jurídico sobre o horizonte de relações sociais não jurídicas- a natureza pensada em termos mecânicos, o jogo das paixões e dos interesses, a disputa pelo poder, que ele foi um dos primeiros a pensar em termos normativamente neutros. Todo esse solo não jurídico sobre o qual se assenta o jurídico é objeto de governo, que Hobbes pensou como governo das paixões e regulação das relações do poder; não apenas e exclusivamente como a imposição da lei por uma instância juridicamente qualificada, isto é, não apenas sob o modelo de uma teoria da soberania.

Hobbes não é desse modo um teórico da soberania em oposição aos teóricos da governança. ${ }^{9} \mathrm{O}$ interesse de Hobbes parece estar justamente em ter sido ele as duas coisas ao mesmo tempo, alguém preocupado em saber como o artificio da lei e do direito pode se instaurar e se manter sobre o solo movediço de uma natureza não jurídica a qual cabe governar e dirigir de modo a tornar possível o próprio direito. Tudo isso, sem que o universo jurídico se dissolva no âmbito das relações de poder e governança, guardando-se a diferença entre as esferas.

${ }^{1}$ Este artigo retoma, refina e unifica os argumentos de outros três artigos já publicados: LIMONGI, M. I. "Direito e Poder: Hobbes e a dissolução do Estado", In: Doispontos v. 6, n. 3, 2009; LIMONGI, M. I. "Hobbes e o poder fora do modelo jurídico da soberania, In: STORCK, A., LISBOA, W. B. (org.) Norma, moralidade e interpretação: temas da filosofia política $e$ do direito, Porto Alegre, Linus editores, 2009; e LIMONGI. M. I. "Direito de natureza em Hobbes: potestas ou potentia?”, In: STOR CK, A., LISBOA, W. B. (org.) Normatividade e argumentação, Porto Alegre, Linus editores, 2013.

${ }^{2}$ Há diferenças significativas entre a teoria da obrigação do DoCive e a do Leviathan. Deixaremos essas diferenças de lado, focando aqui exclusivamente o Leviathan.

${ }^{3}$ No seu curso no Collège de France de 1976, Em defesa da Sociedade, M. Foucault procura mostrar como uma certa literatura emergente entre os séculos XVII e XVIII começou a pensar o poder sob o modelo da guerra e da conquista, e, desse modo, fora do modelo jurídico da 
soberania, que teria sido dominante até então. Nesse contexto, Foucault menciona Hobbes por diversas vezes a fim de recusar-lhe a paternidade desse discurso do qual faz o elogio. Certo, Hobbes "pôs a relação de guerra no fundamento e no princípio das relações de poder" (FOUCAULT, 2005, p. 102). Mas o fez não para pensá-la como algo que "percorre o corpo social" (FOUCAULT, 2005, p. 194) e sim para fazê-la cessar pela instituição da soberania. Deixando de lado o uso estratégico que Foucault faz de Hobbes para trazer à luz o conceito de poder tal como ele próprio se interessa por pensá-lo, e levando em conta apenas o que essa leitura esclarece acerca do modo como Hobbes pensou o poder, ela parece bastante correta quando afirma que, para Hobbes, a instituição da soberania inscreve o poder num quadro jurídico que vem substituir e mesmo negar o da guerra. No entanto, não parece ser verdade que Hobbes tenha pensado o poder apenas sob um modelo jurídico. Pelo contrário, ele parece ter sido um dos primeiros a oferecer um conceito bastante preciso do poder enquanto potência, enquanto uma capacidade de atingir fins, entendida num sentido deliberadamente não jurídico, e a pensar as relações sociais a partir daí.

${ }^{4}$ Yves-Charles Zarka denomina a teoria do poder desenvolvida no capítulo X do Leviathan uma "semiologia do poder", insistindo em que o tratamento conferido ao poder é tal de modo a inscrevê-lo no domínio da linguagem e do signo, e não no da física, o do movimento e composição de movimentos (Cf. ZARKA, 1995, cap. IV). No entanto, se é verdade que o signo desempenha uma papel fundamental na formação das relações de poder, seus efeitos não são apenas da ordem do signo, como sugere Zarka, mas de ordem física, já que a significação do poder leva a uma certa reunião de forças. Sendo assim, a disputa pela honra não é uma outra forma de guerra, por natureza diversa da batalha e do jogo de forças, como por sua vez sugere Foucault, ao dizer que no estado de guerra hobbesiano o que está em questão "não é a batalha, o enfrentamento direto das forças, mas certo estado dos jogos de representações umas contra as outras" (FOUCAULT, 2005, p. 106). Ora, a guerra, concebida por Hobbes como um jogo de signos ou representações, não deixa por isso de ser um jogo de forças e uma forma de batalha.

${ }^{5}$ Sobre o papel na aparência na formação do poder do príncipe, ver a análise de Lefort dos capítulos XV e seguintes de O Príncipe in: LEFORT, 1986, pp. 402 e ss.

${ }^{6}$ Nesse sentido vai a leitura de Foisneau, para quem "encontram-se duas filosofias do poder em Hobbes, a saber, uma filosofia da potentia e uma filosofia da potestas" (FOISNEAU, 1992, p. 102).

${ }^{7}$ Direitos e deveres não são correlativos para Hobbes. Se para Pufendorf ou Locke o direito implica o dever de que ele seja respeitado, sendo que a ênfase recai antes nos deveres e na lei que asseguram o direito do que propriamente no direito, para Hobbes, a ênfase se inverte, sendo o direito natural uma liberdade radical a qual não corresponde nenhum dever, nem mesmo aqueles postos pela lei natural (que, segundo Hobbes, não passam de conselhos da razão incapazes de obrigar e de cancelar o direito), como um elemento primeiro, inaugural, que institui pela via do contrato as obrigações jurídicas e as leis. $\mathrm{O}$ direito assim pensado pode entrar em choque com outro direito, como é o caso do direito de punir e o direito natural de resistir.

${ }^{8}$ Civis uniuspopularitas, no Leviathan latino. Aqui é o Leviathan inglês que cuida de assinalar a natureza do poder que está em questão na popularidade, usando a expressão "popularity of a potent subject".

${ }^{9}$ No sentido do estabelecimento dessa distinção como chave de leitura do pensamento político moderno e da inscrição de Hobbes ao lado dos teóricos da soberania em oposição aos 
teóricos da governança, ver FOISNEAU, L., 2009. Reconhece-se nesse esquema a herança de Foucault, expressamente reivindicada por Foisneau: "conservaremos da lição de Foucault que a soberania e o governo são os dois fios que serviram de trama ao pensamento político moderno." (p. 10)

\section{Referências bibliográficas}

COLLIOT-THÈLENE, C. 2011. La democracie sans $<<$ demos $>>$. Paris: PUF.

FOISNEAU, L. 1992. Le Vocabulaire du pouvoir: potentia/ potestas, power. In: ZARKA Y-C., (org.) Hobbes et son vocabulaire. Paris:Vrin, 1992.

FOISNEAU, L. 2000. Hobbes et la toute-puissance de Dieu. Paris: PUF.

FOISNEAU, L. 2009. Governo e Soberania, o pensamento político modernos de Maquiavel a Rousseau. Porto Alegre: Linus.

FOUCAULT, M. 2005. Em defesa da sociedade. São Paulo: Martins Fontes.

GROTIUS, H. 2005. The rights of war and peace. Tuck, R. (ed.).

Indianapolis: Liberty Fund.

HOBBES, T. 1966. Leviathan.Versão latina, OL, III. In: Thomas Hobbes

Opera Philosophica quae Latine Script. Ed. W. Molesworth. London, 18391845, reimpr.

HOBBES, T. 1974. Leviatã. São Paulo: Abril Cultural.

HOBBES, T. 1985. Leviathan. 4 edição. Macpherson (ed.). Londres:

Pinguin books.

HOBBES, T. 1999. De Corpore. Schuhmann, K. (ed.). Paris:Vrin.

HOBBES, T. 1969. The Elements of Law. F.Tönnies (ed.). London: Frank Cass \& Co.

LEFORT, C. 1986. Le travail de l'oeuvre Machiavel. Paris: Gallimard.

PASCAL, B. 1963. Pensées. In: Lafuma (ed.). Oeuvres. Paris: Seuil.

PUFENDORF. S. 1710. Of the law of nature and nations. Oxford: ECCO

- Eighteen Century Collections Online Print Editions. 
PUFENDORF. S. 1744. De Jure Naturaeet Gentium. Francofurti:

Officina Knochiana (disponível em http://www.archive.org/details/ dejurenaturaeeg01pufe).

SKINNER, Q. 2008. Hobbes and republican liberty. Cambridge University Press.

STRAUSS, L. 1968. Natural Right and History. Chicago University Press.

TUCK, R. 1995. Rights theories, their origin and development. 2 edição.

Cambridge University Press.

VILLEY, M. 2009. A formação do pensamento jurídico moderno. 2 ed. São Paulo: Martins Fontes.

ZARKA,Y-C. (1995.) Hobbes et la pensée politique moderne. Paris: PUF. 


\section{Contents}

\section{Kantian constructivisms and the construction of the principles of} justice in Rawls' work

Antonio Saturnino Braga - antoniofsbraga@uol.com.br Universidade Federal do Rio de Janeiro (UFRJ), Rio de Janeiro, Brasil

abstract The purpose of this paper is to argue for the following theses: firstly, the theories of justice of Habermas and Rawls should be seen as two versions of Kantian constructivism, understood as a metaethical approach that attempts to combine anti-realism and strong cognitivism; secondly, the contrast with Habermas' "reconstructivist constructivism" helps to explain in which way Rawls' theory satisfies the claim to universal validity peculiar to strong cognitivism. In illuminating the fact that Rawls' constructivism is based on the reflective work of the individual consciousness, the contrast with Habermas enables to understand in which sense the concepts of reflective equilibrium and overlapping consensus indicate an ideal that claims universal validity, thereby denying the particularism involved in the coherentist and relativist interpretations of these concepts.

keywords Moral Justification; Kantian Constructivism; Habermas; Rawls; Original Position; Reflective Equilibrium

\section{Justice as Fairness and the Problem of Reasonableness}

Denis Coitinho Silveira - deniscoitinhosilveira@gmail.com

Universidade do Vale dos Sinos (UNISINOS), São Leopoldo, Brasil

abstract In this paper I want to show the importance of the concept of reasonable in John Rawls's theory of justice as fairness and, also, I want to explain the problem of reasonableness in this theory. The starting point will be to stress the 
requirement of reasonableness that is made in justice as fairness on the moral agent. Later, I will identify some criticism of these criteria. I will show the criticism made by Estlund about the insularity of the concept of reasonableness and the necessity of truth and the criticism established by Timmons and Gaus regarding the requirement of reasonableness as excessive and ineffective too. The next step is to try to answer these criticisms and, at the end of this paper, I will lay down an argument about a kind of reasonable moral responsibility that may be contained in justice as fairness.

keywords Fairness; Reasonableness; Burdens of reason; Burdens of judgment; Responsibility; Rawls

\section{The debate of divergence: an evaluation of Michael Sandel's criticisms to John Rawls' liberalism}

Flávio Azevedo Reis - flavio_a_reis@hotmail.com

Universidade do Estado de São Paulo (USP), São Paulo, Brasil

abstract The main objective of Micheal Sandel's Liberalism and the Limits of Justice was to attack the concept of deontology, as formulated by John Rawls. In this article, I argue that Sandel interpreted the concept of deontology in a misleading way. There is a difference between how Rawls defined this concept and how it was interpreted by Sandel. Given this, the first part of this article will analyze the way Sandel interpreted the Rawlsian concept of deontology. The second part presents an assessment of the clash between the two authors in light of the differences in the way both of them understood the meaning of deontology in political liberalism.

keywords Liberalism; Communitarism; John Rawls; Michael Sandel; Deontology; Theory of Justice

\section{Political Economy and the roots of Rawls' original position}

Fabrício Pontin - fpontin@gmail.com

Southern Illinois University, Illinois, USA

abstract The impact and relevance of economic theory to the development of "A Theory of Justice" are often left aside in the immense literature regarding the works of John Rawls. And yet, understanding the elements of political economy in Rawls' work is fundamental for the comprehension of why Rawls' will abandons a utilitarian 
approach to political philosophy and, consequentially, for our understanding of the main issues that motivate the notion of Justice as Fairness. This article has two mains goals: First, to describe the influence of John Stuart Mill, Kenneth Arrow and Vilfredo Pareto in the methodological turn found in the idea of the Original Position; and second, to describe the historical elements that are presupposed for the conceivability of Rawls' ideals. I conclude the present paper with some remarks suggesting a historicist and phenomenological complement to the ideal descriptions found in political liberalism as understood by Rawls.

keywords Political Economy; Political Liberalism; Original Position; Rational Choice

\section{Ethics, economics and justice: social choice in the thought of Sen and Smith}

Fábio Creder - fcreder@homail.com

Universidade Estadual do Rio de Janeiro, Rio de Janeiro, Brasil

Luiz Bernardo Leite Araujo - lbaraujo@uerj.br

Universidade Estadual do Rio de Janeiro, Rio de Janeiro, Brasil

abstract This article aims to examine Adam Smith's deep and broad influence on the thought of Amartya Sen, especially concerning the issue of social justice that pervades the writings of both authors. First, we will analyze Sen's revision of the work of Smith to refute the interpretation still prevalent, that makes use of certain excerpts from The Wealth of Nations as the main reference in defending the deregulation of markets and in exempting the economic thought from any consideration of moral values, demonstrating how Sen draws on Smith's ideas to explain the impoverishment of economics when it departs from ethics. Then, we will consider the overwhelming influence of the Smithian thought on Sen's criticism of the theory of rational choice through his distinctive formulation of the theory of social choice, whose importance was rightly recognized, earning him the Nobel Prize in Economics in 1998.

keywords Amartya Sen; Adam Smith; Social Justice; Ethics; Economics; Social Choice.

\section{The Concepts of Just and Unjust in Aristotle: between EN V, 1 and EN V, 9}

Mateus de Campos Baldin - mateus.baldin@gmail.com

Universidade Federal do Rio Grande do Sul (UFRGS), Porto Alegre, Brasil 
abstract Some authors of Jurisprudence, especially Michel Villey, tried to present what they thought to be the aristotelic theory of justice, grounding in it their own theories. To Villey, specifically, "the right" would be the correct translation of the Greek to dikaion. To defend, based on Aristotle, a conception of the just that refuses subjective elements of a theory of action is an error. And this error lies in ignoring a redefinition of to dikaion made by Aristotle in Chapter 9 of Book V of Nicomachean Ethics. There, Aristotle adds to the objective conditions of the just and the unjust (EN V, 1-7) some subjective conditions referring to person who suffers the action. Only after correctly understanding these conditions we will be able to correctly understand the aristotelic theory of justice. As Villey and other authors ignore it, they err interpreting Aristotle and using him to found their own theories.

keywords Aristotle; Michel Villey; Justice; Nicomachean Ethics

\section{Potentia and potestas in Hobbes' Leviathan}

Maria Isabel Limongi - belimongi@yahoo.com.br Universidade Federal do Paraná (UFPR), Curitiba, Brasil

abstract In the Leviathan, power can be understood in two different senses, which are carefully discriminated in its Latin version by the use of the terms potentia and potestas to translate, depending on the context and the type of power concerned, the English power. Potentia and potestas, although types of power of a different nature - one, the physical power that bodies have to take effect on each other; the other, the juridical power, out of which legal effects as justice itself come about -, are mutually implicated in the intertwining of juridical representations. This article aims to explore the consequences that follow from this ambivalent concept of power to think about justice and natural right.

keywords Leviathan; Hobbes; Power; Right; Potentia; Potestas; Jus 


\section{Chamada para artigos Call for papers}

vol. 10 número 2

Temas de Filosofia na Antiguidade (outubro de 2013)

Prazo para submissão dos artigos: 20 de maio de 2013

vol. 11 número 1

Filosofia e Pintura (abril de 2014)

Prazo para submissão dos artigos: 20 de julho de 2013

vol. 10 number 2

Issues on Philosophy in Antiquity (October 2013)

Deadline to submissions: May, 20, 2013.

vol. 11 number 1

Philosophy and Painting (April 2014)

Deadline to submissions: July, 20, 2013. 
172

$\bullet$ 


\section{Instruções aos autores}

1. A Revista doispontos aceita artigos originais e resenhas bibliográficas nas seguintes línguas: português, inglês, francês, italiano e espanhol. 2. Serão examinados apenas os artigos e resenhas bibliográficas que abordarem o tema selecionado para o volume em pauta, anunciado nos volumes precedentes. Salvo em casos excepcionais, os artigos não deverão ultrapassar 14.000 palavras, incluindo referências bibliográficas e notas. As resenhas bibliográficas não deverão ultrapassar, em princípio, 4.500 palavras, incluindo referências bibliográficas e notas, e, devem apresentar, no início do texto, a referência completa das obras analisadas. 3. A decisão sobre a publicação de artigos cabe aos Editores a partir da avaliação do Conselho Editorial da Revista. Cada artigo receberá dois pareceres, que podem: (a) indicar a publicação; (b) indicar a publicação, desde que sejam feitas revisões; ou (c) negar a publicação. A publicação dos artigos aprovados pelos pareceristas estará, contudo, condicionada ao orçamento da Revista. 4. Os autores serão notificados da recepção das colaborações. 5. A decisão sobre a publicação de resenhas cabe ao Editor de Resenhas. 6. Os Editores reservam-se o direito de sugerir ao autor modificações de forma, a fim de adequar as colaborações ao padrão editorial e gráfico da revista. 7. As afirmações e conceitos emitidos em artigos assinados são de absoluta responsabilidade dos seus autores. A apresentação das colaborações ao corpo editorial implica a cessão da prioridade de publicação à Revista doispontos, bem como a cessão dos direitos autorais dos textos publicados, que só poderão ser reproduzidos sob a autorização expressa dos Editores. Os colaboradores manterão o direito de reutilizar o material publicado em futuras coletâneas de sua obra, sem o pagamento de taxas à Revista doispontos. A permissão para reedição ou tradução do material publicado, por terceiros, não será feita sem o consentimento do autor. NORMAS PARA APRESENTAÇÃO DE ARTIGO 1. O envio de artigos e resenhas bibliográficas deve ser feito eletronicamente, pelo Sistema Eletrônico de Revista (SER), disponível na página da Pró-Reitoria 
de Pesquisa e Pós-Graduação da Universidade Federal do Paraná (http://www.prppg.ufpr.br/), que dá acesso à versão eletrônica da doispontos. 2. Os artigos deverão ser obrigatoriamente acompanhados: (a) de um resumo do texto em português e em inglês contendo entre 75 e 150 palavras; (b) de uma relação de seis palavras-chave, para efeito de indexação bibliográfica. 3. As referências bibliográficas utilizadas serão apresentadas no final do artigo, listadas em ordem alfabética, obedecendo às seguintes normas (NBR 6023): Livro: SOBRENOME, Nome (abreviado). Ano. Título em itálico: subtítulo. Número da edição, caso não seja a primeira. Local da publicação: Nome da editora. Coletânea: SOBRENOME, Nome (abreviado). Ano. Título do ensaio. In: SOBRENOME, Nome (abreviado) do(s) organizador (es). Título da coletânea em itálico: subtítulo. Número da edição, caso não seja a primeira. Local da publicação: nome da editora. Artigo em periódico: SOBRENOME, Nome (abreviado). Ano. Título do artigo. Nome do periódico em itálico, local da publicação, volume e número do periódico, intervalo de páginas do artigo, período da publicação. Dissertações e teses: SOBRENOME, Nome (abreviado). Ano. Título em itálico. Local. Número total de páginas. Grau acadêmico e área de estudos [Dissertação (Mestrado) ou Tese (Doutorado)]. Instituição em que foi apresentada. Internet (documentos eletrônicos): SOBRENOME, Nome (abreviado). (Ano). Título em itálico, [Online]. Produtor. Disponibilidade: acesso. [data de acesso]. 4. Solicita-se observar rigorosamente a sequência e a pontuação indicadas. 5. As referências a autores no decorrer do artigo devem subordinarse ao seguinte esquema: (SOBRENOME DE AUTOR, data) ou (SOBRENOME DE AUTOR, data, página). Ex.: (DESCARTES, 1979) ou (DESCARTES, 1979, p. 64). Diferentes títulos do mesmo autor publicados no mesmo ano serão identificados por uma letra após a data. Ex.: (PLATÃO, 1989a), (PLATÃO, 1989b). 6. As notas de rodapé deverão ser de natureza substantiva, limitadas ao mínimo indispensável e indicadas por algarismos arábicos em ordem crescente. 7. A Revista doispontos não se obriga a devolver os originais das colaborações enviadas por correio. 8. $\mathrm{O}(\mathrm{s})$ autor (es) de trabalho publicado na Revista doispontos receberá (ão) três exemplares da revista. 
doispontos@ufpr.br

endereços eletrônicos da doispontos:

www.ser. ufpr.br/doispontos

www.filosofia.ufpr.br/ 
176

$\bullet$ 